Prepared in cooperation with the County of Maui Department of Water Supply

\title{
Effects of Agricultural Land-Use Changes and Rainfall on Ground-Water Recharge in Central and West Maui, Hawai'i, 1926-2004
}

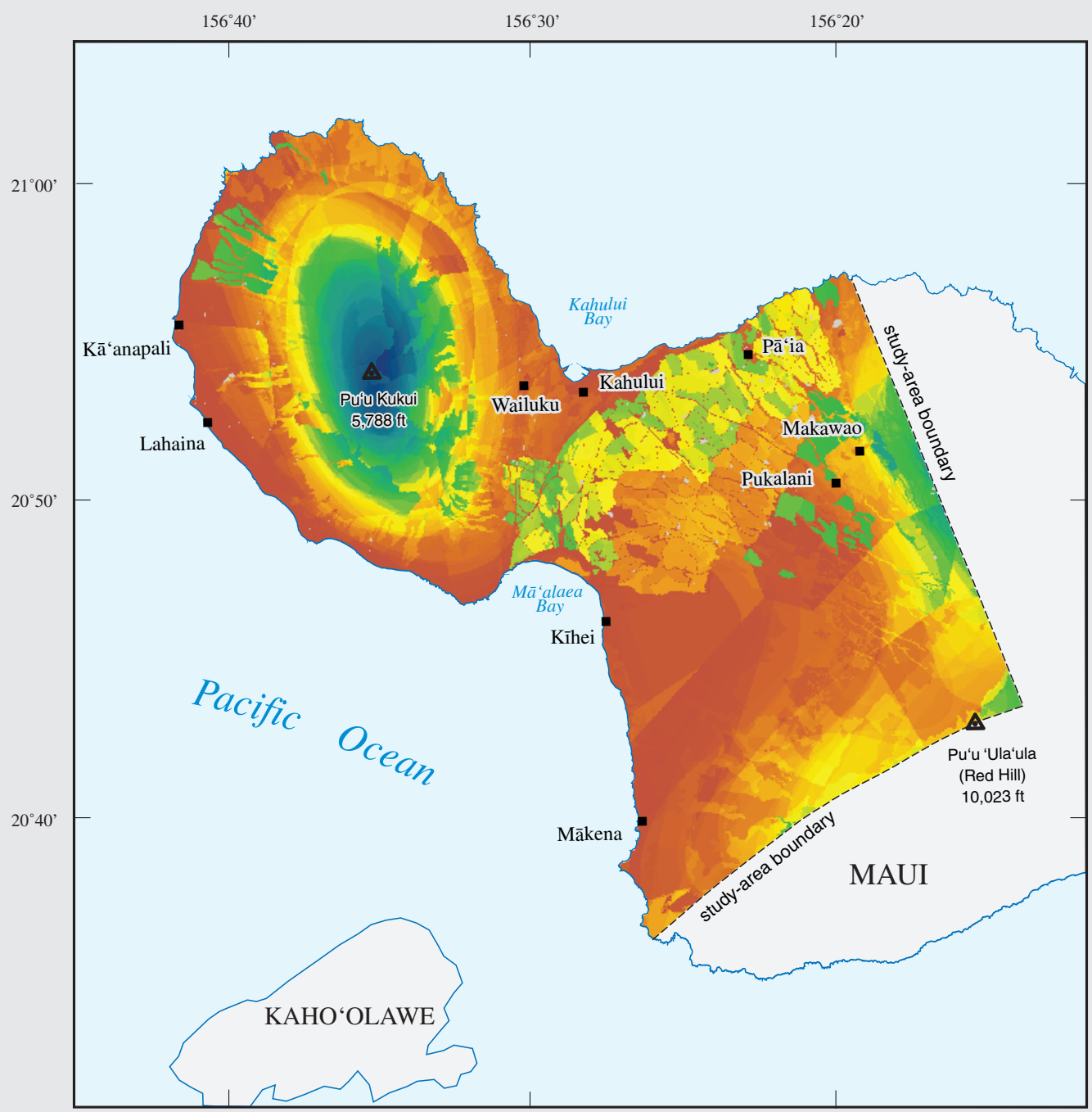

Scientific Investigations Report 2007-5103 
COVER

Relative distribution of estimated ground-water recharge during 2000-04 in central and west Maui, Hawai'i. Estimated recharge is shown using a color scale with red representing lowest recharge and violet representing highest recharge. 


\section{Effects of Agricultural Land-Use Changes and Rainfall on Ground- Water Recharge in Central and West Maui, Hawai' í, 1926-2004}

By John A. Engott and Thomas T. Vana

Prepared in cooperation with the County of Maui Department of Water Supply

Scientific Investigations Report 2007-5103 


\title{
U.S. Department of the Interior DIRK KEMPTHORNE, Secretary
}

\author{
U.S. Geological Survey \\ Mark D. Myers, Director
}

U.S. Geological Survey, Reston, Virginia: 2007

For product and ordering information:

World Wide Web: http://www.usgs.gov/pubprod

Telephone: 1-888-ASK-USGS

For more information on the USGS--the Federal source for science about the Earth, its natural and living resources, natural hazards, and the environment:

World Wide Web: http://www.usgs.gov

Telephone: 1-888-ASK-USGS

Any use of trade, product, or firm names is for descriptive purposes only and does not imply endorsement by the U.S. Government.

Although this report is in the public domain, permission must be secured from the individual copyright owners to reproduce any copyrighted materials contained within this report.

Suggested citation:

Engott, J.A., and Vana, T.T., 2007, Effects of Agricultural Land-Use Changes and Rainfall on Ground-Water Recharge in Central and West Maui, Hawai'i, 1926-2004: U.S. Geological Survey Scientific Investigations Report 2007-5103, 56 p.

Manuscript approved for publication, May 23, 2007 


\section{Executive Summary}

As a result of rapid population growth, annual ground-water withdrawals from the '⿳亠丷厂ao aquifer system, the principal source of domestic water supply for the Island of Maui (fig. E1), nearly doubled during the period 1970-2005. Increasing rates of withdrawal have coincided with decreasing rates of agricultural irrigation and a recent drought. As a result, water levels in the 'İao aquifer system have declined, while the chloride concentration of water pumped from wells has increased. These conditions have raised concerns about the long-term sustainability of withdrawals from existing wells in the aquifer system.

To ensure prudent management of ground-water resources and plan for sustainable growth on the island, the County of Maui Department of Water Supply entered into a cooperative agreement with the U.S. Geological Survey to increase overall understanding of the groundwater flow system and recharge processes in central and west Maui. This report documents the (1) development of a water-budget method for calculating daily ground-water recharge in central and west Maui, (2) application of the method to estimate historical ground-water recharge during the period 1926-2004, and (3) application of the method to estimate mean recharge for hypothetical land-use and rainfall conditions.

\section{Agricultural Land Use}

The plantation-scale cultivation of sugarcane (and, to lesser degrees, pineapple and macadamia nuts) has profoundly affected the hydrology of central and west Maui (fig. E1). Since the early 20th century, about 100 billion gallons of surface water has been diverted each year from island streams for the irrigation of crops within the study area. More than half of this diverted water, about 59 billion gallons per year, originates outside the study area, in east Maui. Under natural conditions, most diverted surface water would flow to the ocean; instead, this water has been artificially applied to the plant-soil system, creating a net increase in ground-water recharge. Irrigation-enhanced recharge greatly affects the ground-water system within the study area, and assessing historical changes in the amount and spatial distribution of irrigationenhanced recharge is critical to understanding the island's ground-water system.

Overall irrigation rates in the study area (fig. E1) have been steadily decreasing since the 1970s, when large-scale sugarcane plantations began a conversion from furrow to more efficient drip irrigation methods and a reduction in the amount of acreage dedicated to sugarcane production. During the period 1979-2004, overall agricultural land use decreased about 21 percent, while sugarcane acreage decreased about 22 percent. During the same period, on the leeward (Lahaina) side of West Maui Mountain, sugarcane cultivation ceased altogether. The decrease in irrigation has coincided recently with periods of below-average rainfall, creating the potential for substantially reduced recharge rates in many areas.

\section{Water-Budget Method}

The daily water-budget method used in this study to estimate ground-water recharge is a mass-balance procedure that accounts for water entering, leaving, and being stored within the plant-soil system. Water entering the plant-soil system is the sum of rainfall, irrigation, and fog drip, whereas water leaving the plant-soil system is the sum of runoff, evapotranspiration, and ground-water recharge. The water-budget method can be used to estimate recharge if the values of other components are known or can be reasonably estimated. Ground-water recharge occurs when more water enters the plant-soil system than can be held in the plant-soil system, given its soil-moisture storage capacity, antecedent moisture content, and moisture losses due to evapotranspiration. In this study, the water budget was calculated on a daily basis and aggregated over longer periods of interest. 


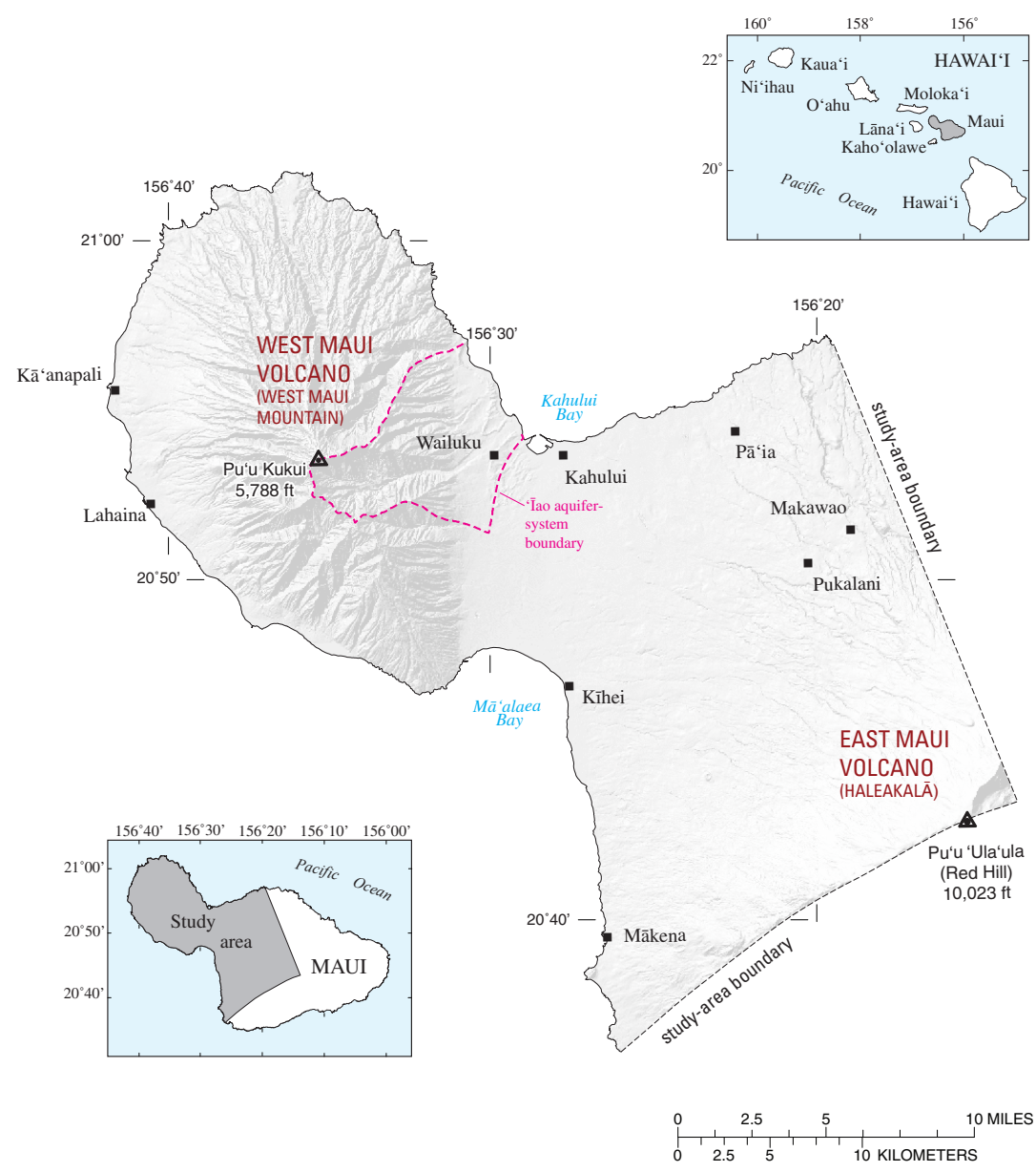

Figure E1. Central and west Maui, Hawai'i.

\section{Water-Budget Components}

Rainfall, fog drip, and irrigation are water-budget inflows. A time series of daily rainfall distribution in the study area was constructed from maps of monthly mean rainfall distribution and data from selected rain gages. Rainfall data were obtained from the Hawai ${ }^{\circ} \mathrm{i}$ Commission on Water Resource Management, the National Climatic Data Center, and the National Weather Service. Fog drip, a term commonly used in Hawai' $i$ to describe cloud water intercepted by vegetation that subsequently drips or flows down branches or stems to the ground, was estimated on the basis of results from several previous studies and data collected as part of this study. On the windward side of West Maui Mountain, where fog is persistent, fog drip was included in the water budget and estimated to be 20 percent of rainfall at altitudes above 2,000 $\mathrm{ft}$. Irrigation rates and methods vary over time and by crop type. Sugarcane, pineapple, and macadamia irrigation was estimated in this study on the basis of interviews with plantation managers.

Runoff and evapotranspiration are water-budget outflows. Runoff was estimated by developing a relation between runoff and rainfall. Streamflow data for each drainage area were analyzed to determine the part of flow attributable to direct runoff. A ratio of direct runoff to 
rainfall was then calculated and applied over each drainage area. Where insufficient streamflow data were available, ratios of direct runoff to rainfall were estimated from soil types. Evapotranspiration was estimated from pan evaporation multiplied by an appropriate vegetation-specific factor-a pan coefficient. Various sources of pan-evaporation data were used to create a map of annual pan evaporation for the study area. Monthly variation in pan evaporation was estimated from evaporation data collected from individual stations in the study area.

Soil-moisture storage capacity is the maximum amount of water that can be held by surface-tension forces within the pores of a given soil layer. The soil-moisture storage capacity is the product of available water capacity and root depth. Available water capacity primarily depends on soil type, whereas root depth is generally a function of vegetation type. U.S. Department of Agriculture soil maps and tables were sources for available water capacities, and State of Hawai' $i$ and National Oceanic and Atmospheric Administration land-use and landcover maps were sources for vegetation types.

\section{Historical Recharge (1926-2004)}

Estimated recharge for central and west Maui declined 44 percent during the period 1979-2004 (fig. E2). The period 1926-79 had the highest estimated recharge; irrigation rates during this period were at least 50 percent higher than in any other period considered. The period 2000-04 had the lowest estimated recharge; irrigation rates during this period were 46 percent lower than during 1926-79, and rainfall was the lowest of any period.

The spatial distributions of recharge over the period 1926-2004 indicate several patterns: (1) changes in agricultural land use resulted in corresponding changes in recharge distribution; (2) the reduction in sugarcane irrigation rates resulted in less pronounced differences between the recharge rates of adjacent sugarcane and non-sugarcane lands; (3) in nonagricultural areas, the spatial distributions of recharge varied according to the amount and spatial distribution of rainfall; and (4) in agricultural areas, the spatial distribution of recharge varied with the distribution of rainfall and irrigation.

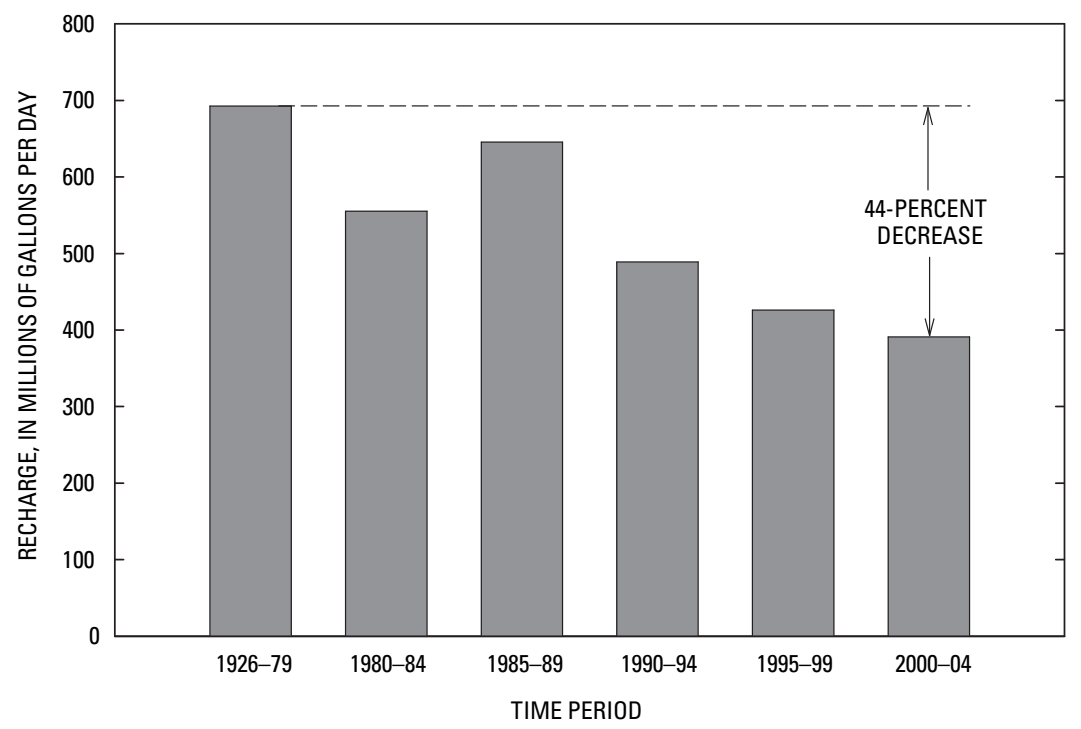

Figure E2. Estimated ground-water recharge in central and west Maui, Hawai'i, for six time periods spanning 1926-2004. 


\section{Comparison with Previous Investigations}

In the 'Īao area (fig. E1), recharge estimates are consistently higher than those calculated by Shade (1997). The inclusion of fog drip in this study, and the higher runoff calculated by Shade (1997), are largely responsible for these higher estimates. In this study, fog drip contributed significant water inflow to the plant-soil system, in addition to rainfall and irrigation, whereas Shade (1997) omitted fog drip. Runoff estimates in this study are lower than Shade's (1997) for each scenario considered. This difference is especially significant when examined as a percentage of total water inflow.

In most central and west Maui aquifer systems, recharge estimates calculated by using the methods of this study are significantly higher than those in the State of Hawai 'i's Water Resources Protection Plan (WRPP) (Commission on Water Resource Management, 1990). The reasons for differences in recharge estimates are related to the methods used to estimate the individual water-budget components. The methods used in this study generally result in higher estimates of water inflow than those of the WRPP, lower estimates of runoff than those of the WRPP, and lower estimates of evapotranspiration than those of the WRPP. This combination results in the recharge estimates of this study being generally higher than those of the WRPP.

\section{Recharge for Hypothetical Land-Use and Rainfall Conditions}

Results from hypothetical land-use conditions indicate that in comparison with current conditions, a cessation of agriculture in central and west Maui would reduce mean groundwater recharge by 18 percent and that a period of drought, identical to the period 1998-2002, would reduce mean recharge by 27 percent. Mean recharge would decrease 46 percent if this drought were to occur after a cessation of agriculture in central and west Maui.

\section{Sensitivity}

Uncertainty exists in many of the water-budget components and parameters used in this study. To analyze the effect of uncertainty on estimated recharge, the water budget was rerun while changing one component or parameter value at a time within a reasonable range. The components and parameters tested were (1) initial soil moisture, (2) root depth, (3) runoff-torainfall ratio, (4) available water capacity, (5) fog-drip-to-rainfall ratio, (6) pan coefficient, (7) irrigation volume, and (8) reservoir seepage. Those with significant effects on recharge were root depth, runoff-to-rainfall ratio, pan coefficient, and irrigation volume; those with only minor effects on recharge were initial soil moisture, available water capacity, fog-drip-to-rainfall ratio, and reservoir seepage.

\section{References Cited}

Commission on Water Resource Management, 1990, Water resources protection plan, June 1990: Hawai'i Department of Land and Natural Resources, 2 v.

Shade, P.J., 1997, Water budget for the Iao area, Island of Maui, Hawaii: U.S. Geological Survey Water-Resources Investigations Report 97-4244, 25 p. 


\section{Contents}

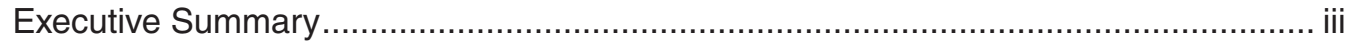

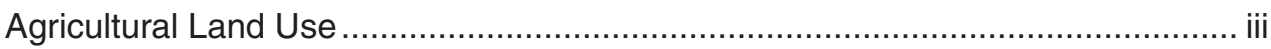

Water-Budget Method ....................................................................................... ii

Water-Budget Components .............................................................................. iv

Historical Recharge (1926-2004)...............................................................

Comparison with Previous Investigations ....................................................... vi

Recharge for Hypothetical Land-Use and Rainfall Conditions ............................. vi

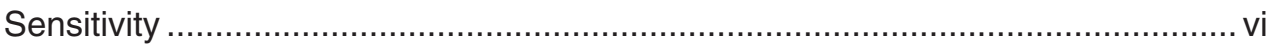

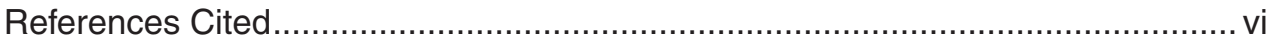

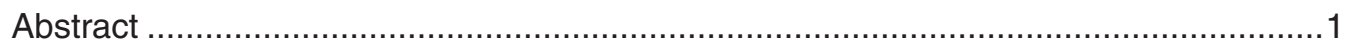

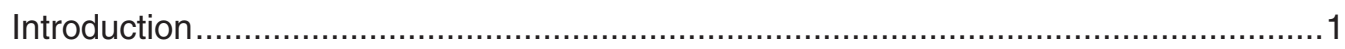

Purpose and Scope

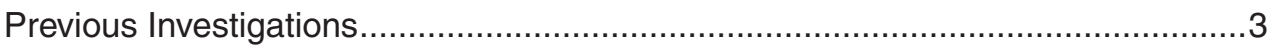

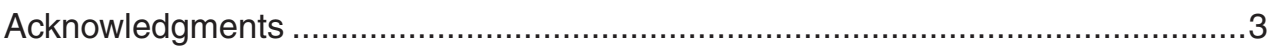

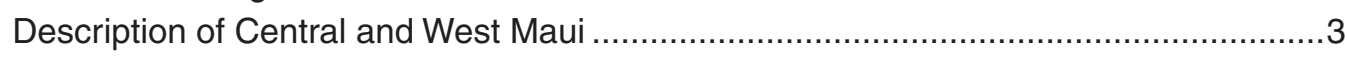

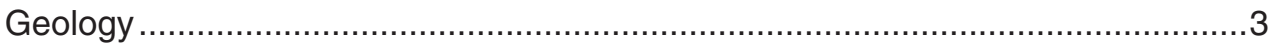

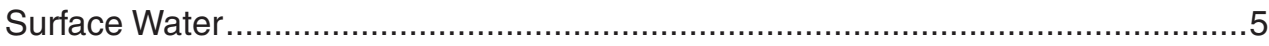

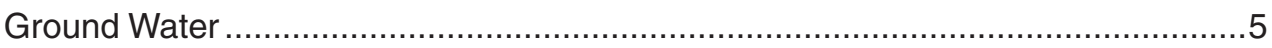

Historical Agricultural and Urban Land Uses in Central and West Maui........................5

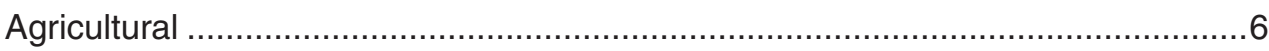

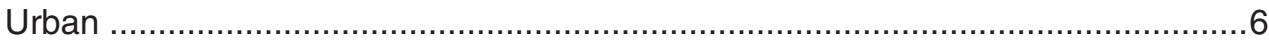

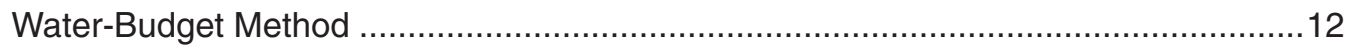

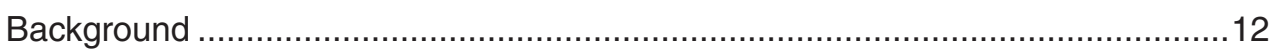

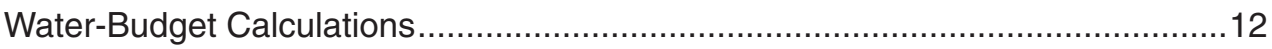

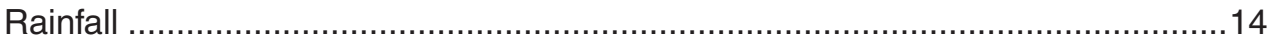

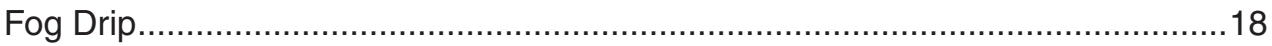

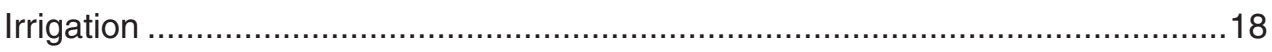

Sugarcane Irrigation..................................................................... 18

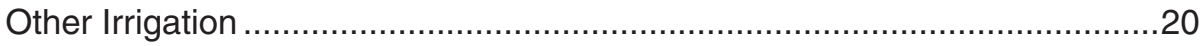

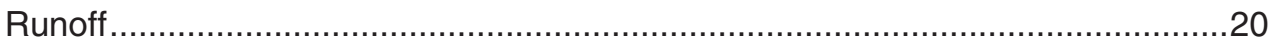

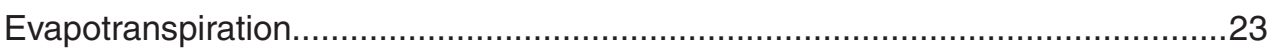

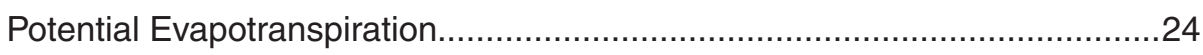

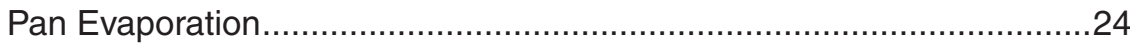

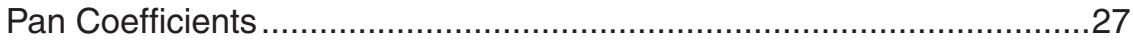

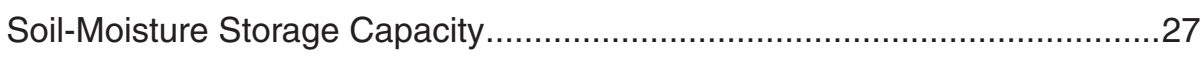

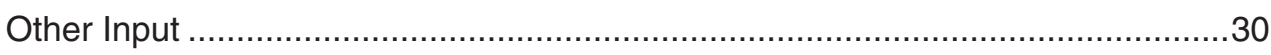

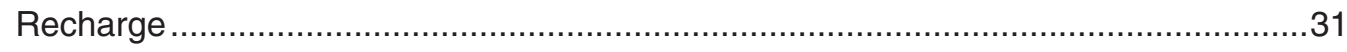

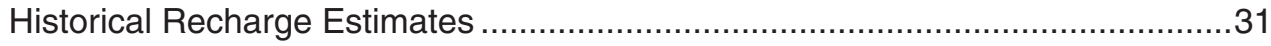

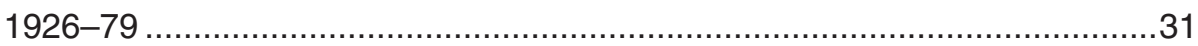

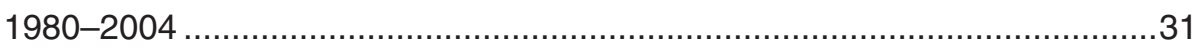

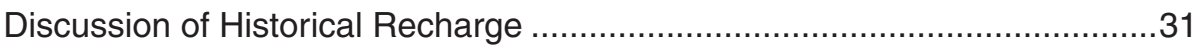

Comparison with Previous Investigation of the 'Īao Area ...................................41 
Comparison with Water Resources Protection Plan...........................................41

Effects of Changing Agricultural Land Use and Rainfall .....................................4

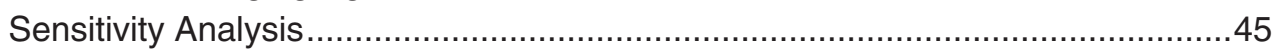

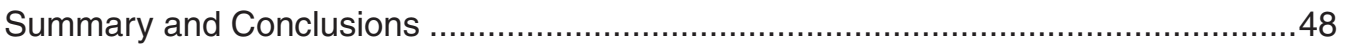

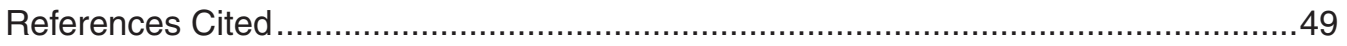

Appendix A. Description of USGS Climate Network and Methods for Calculating

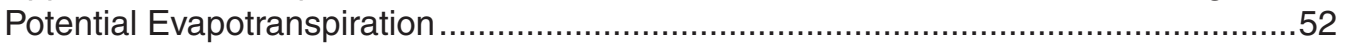

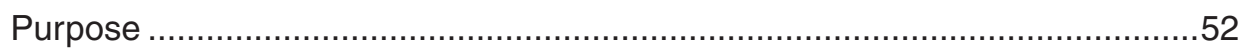

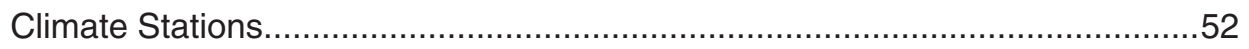

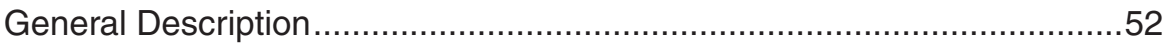

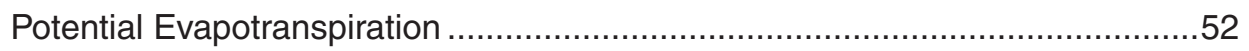

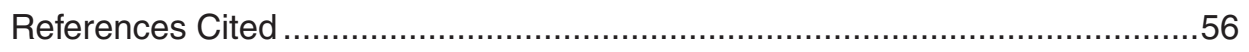

\section{Figures}

E1. Central and west Maui, Hawai'i................................................................. iv

E2. Estimated ground-water recharge in central and west Maui, Hawai'i, for six time periods spanning 1926-2004 .......................................................

1. Study area, central and west Maui, Hawai'i ...............................................

2. Generalized land use for six time periods in central and west Maui, Hawai'i

3. Agricultural land use by crop type for selected time periods from 1926-2004, central and west Maui, Hawai'i ................................................12

4. Generalized water-budget flow chart ....................................................... 12

5. Mean annual rainfall and area of fog contribution in central and west Maui,

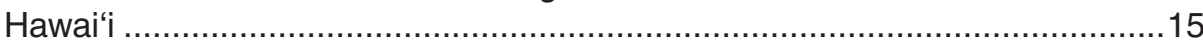

6. Measured and estimated monthly rainfall at three gages on the Island of Maui, Hawai'i.

7. Runoff regions and runoff zones used in the water-budget calculation for central and west Maui, Hawai'i

8. Mean annual pan evaporation and pan-evaporation zones used in this study....

9. Mean ratio of monthly-to-annual pan evaporation for the pan-evaporation zones used in the water-budget calculation for central and west Maui, Hawai'i

10. Pan coefficients used in the water-budget calculation for different growth stages of sugarcane

11. Distribution of estimated mean recharge for six historical scenarios, central and west Maui, Hawai'i

12. Estimated recharge for six historical scenarios, 1926-2004, central and west Maui, Hawai'i

13. Estimated water-budget components for six historical scenarios, 1926-2004, central and west Maui, Hawai'i

14. Estimated monthly average rainfall, irrigation, and recharge, 1926-2004, for central and west Maui, Hawai'i 
15. Locations of aquifer systems and surficial sedimentary deposits in central and west Maui, Hawai'i

16. Effect of land-use change on estimated ground-water recharge in central and west Maui, Hawai'i .....

17. Five-year moving average of the mean ratio of measured annual rainfall to mean annual rainfall for the 33 rainfall gages used in the water-budget calculation for central and west Maui, Hawai'i

18. Effect of rainfall reduction on estimated ground-water recharge in central and west Maui, Hawai'i

A1. Mean monthly potential evapotranspiration at the climate stations on West Maui Mountain

\section{Tables}

1. Changes in agricultural and urban land use by region and time period for central and west Maui, Hawai'i

2. Previous water-budget investigations related to central and west Maui, Hawai'i

3. Error in mean monthly rainfall estimated using surrogate weighting factors for selected rain gages, central and west Maui, Hawai'i

4. Estimated monthly irrigation depths used in the water-budget calculation for central and west Maui, Hawai'i

5. USGS stream-gaging stations used to calculate ratios of runoff to rainfall for this study.

6. Monthly and annual runoff-to-rainfall ratios for runoff zones, central and west Maui, Hawai'i

7. Ratios of monthly-to-annual pan evaporation for each pan-evaporation zone used in the water-budget calculation for central and west Maui, Hawai'i

8. Land-cover parameters used in the water-budget calculation for central and west Maui, Hawai'i

9. Average available water capacities for soils in central and west Maui, Hawai'i

10. Values of miscellaneous parameters used in the water-budget calculation for central and west Maui, Hawai'i

11. Mean water budgets for historical and hypothetical land-use and rainfall conditions, central and west Maui, Hawai'i

12. Mean monthly water budgets for six historical scenarios, central and west Maui, Hawai'i...

13. Comparison of water-budget estimates by this study and Shade (1997) for the 'lao area of Maui, Hawai'i

14. Comparison of water-budget estimates for natural conditions by this study with the Water Resources Protection Plan (Commission on Water Resource Management, 1990)

15. Results of sensitivity testing for selected water-budget inputs used in the calculation of ground-water recharge for central and west Maui, Hawai' $i$ 


\section{Conversion Factors}

\begin{tabular}{|c|c|c|}
\hline Multiply & By & To obtain \\
\hline \multicolumn{3}{|c|}{ Length } \\
\hline inch (in.) & 2.54 & centimeter $(\mathrm{cm})$ \\
\hline foot $(\mathrm{ft})$ & 0.3048 & meter $(\mathrm{m})$ \\
\hline mile (mi) & 1.609 & kilometer $(\mathrm{km})$ \\
\hline \multicolumn{3}{|c|}{ Area } \\
\hline acre & 4,047 & square meter $\left(\mathrm{m}^{2}\right)$ \\
\hline square mile $\left(\mathrm{mi}^{2}\right)$ & 2.590 & square kilometer $\left(\mathrm{km}^{2}\right)$ \\
\hline \multicolumn{3}{|c|}{ Volume } \\
\hline gallon (gal) & 3.785 & liter $(\mathrm{L})$ \\
\hline million gallons (Mgal) & 3,785 & cubic meter $\left(\mathrm{m}^{3}\right)$ \\
\hline \multicolumn{3}{|c|}{ Flow rate } \\
\hline cubic foot per second $\left(\mathrm{ft}^{3} / \mathrm{s}\right)$ & 0.02832 & cubic meter per second $\left(\mathrm{m}^{3} / \mathrm{s}\right)$ \\
\hline cubic foot per second $\left(\mathrm{ft}^{3} / \mathrm{s}\right)$ & 0.6464 & million gallons per day (Mgal/d) \\
\hline million gallons per day $(\mathrm{Mgal} / \mathrm{d})$ & 0.04381 & cubic meter per second $\left(\mathrm{m}^{3} / \mathrm{s}\right)$ \\
\hline
\end{tabular}

Temperature in degrees Celsius $\left({ }^{\circ} \mathrm{C}\right)$ may be converted to degrees Fahrenheit $\left({ }^{\circ} \mathrm{F}\right)$ as follows:

${ }^{\circ} \mathrm{F}=\left(1.8 \times{ }^{\circ} \mathrm{C}\right)+32$

Temperature in degrees Fahrenheit $\left({ }^{\circ} \mathrm{F}\right)$ may be converted to degrees Celsius $\left({ }^{\circ} \mathrm{C}\right)$ as follows:

${ }^{\circ} \mathrm{C}=\left({ }^{\circ} \mathrm{F}-32\right) / 1.8$

Vertical coordinate information is referenced to the mean sea level.

Horizontal coordinate information is referenced to the North American Datum of 1983 (NAD 83).

Elevation, as used in this report, refers to distance above the vertical datum.

\section{Acronyms}

$\begin{array}{ll}\text { Acronyms } & \\ \text { CWRM } & \text { Hawai'i Commission on Water Resource Management } \\ \text { GIRAS } & \text { Geographic Information Retrieval and Analysis System } \\ \text { GIS } & \text { Geographic Information System } \\ \text { HC\&S } & \text { Hawaiian Commercial and Sugar Co. } \\ \text { MDWS } & \text { County of Maui Department of Water Supply } \\ \text { ML\&P } & \text { Maui Land and Pineapple Co. } \\ \text { NCDC } & \text { National Climatic Data Center } \\ \text { NOAA } & \text { National Oceanic and Atmospheric Administration } \\ \text { NWS } & \text { National Weather Service } \\ \text { USGS } & \text { U.S. Geological Survey } \\ \text { WRPP } & \text { Water Resources Protection Plan }\end{array}$




\title{
Effects of Agricultural Land-Use Changes and Rainfall on Ground-Water Recharge in Central and West Maui, Hawai' í, 1926-2004
}

\author{
By John A. Engott and Thomas T. Vana
}

\section{Abstract}

Concern surrounding declines in ground-water levels and an increase in the chloride concentration of water pumped from wells in the 'ITao aquifer system on the Island of Maui has prompted an investigation into the long-term sustainability of current (2006) and future ground-water withdrawals. As part of this investigation, a water budget for central and west Maui was calculated from which (1) ground-water recharge was estimated for the period 1926-2004 and (2) the effects of agricultural land-use changes and drought were analyzed.

Estimated mean ground-water recharge decreased 44 percent from 1979 to 2004 in central and west Maui. Reduction in agricultural irrigation, resulting from more efficient irrigation methods and a reduction in the acreage used for agriculture, is largely responsible for the declining recharge. Recently, periods of lower-than-average rainfall have further reduced recharge. During the period 1926-79, ground-water recharge averaged $693 \mathrm{Mgal} / \mathrm{d}$, irrigation averaged $437 \mathrm{Mgal} / \mathrm{d}$, and rainfall averaged $897 \mathrm{Mgal} / \mathrm{d}$. During the period 2000-04, ground-water recharge averaged $391 \mathrm{Mgal} / \mathrm{d}$, irrigation averaged $237 \mathrm{Mgal} / \mathrm{d}$, and rainfall averaged $796 \mathrm{Mgal} / \mathrm{d}$.

Simulations of hypothetical future conditions indicate that a cessation of agriculture in central and west Maui would reduce mean ground-water recharge by 18 percent in comparison with current conditions, assuming that current climatic conditions are the same as the long-term-average conditions during the period 1926-2004. A period of drought identical to that of 1998-2002 would reduce mean recharge by 27 percent. Mean recharge would decrease by 46 percent if this drought were to occur after a cessation of agriculture in central and west Maui. Whereas droughts are transient phenomena, a reduction in agricultural irrigation is likely a permanent condition.

\section{Introduction}

Recent population growth on the Island of Maui, Hawai ' $i$, has led to an increase in ground-water demand. The resident population on the island increased more than 200 percent during the period 1970-2000: from 38,691 to 117,644 (Hawai'i Department of Business, Economic Development, and Tourism, 2004). The 'Īao aquifer system (fig. 1) is the principal source of domestic water supply for the Island of Maui. Ground-water withdrawals from this aquifer system increased from less than 10 million gallons per day (Mgal/d) during 1970 to about $17 \mathrm{Mgal} / \mathrm{d}$ during 2005. During this same period, water levels have declined, the transition zone between freshwater and saltwater has risen, and the chloride concentration of water pumped from wells in the 'Tao aquifer system has increased (Meyer and Presley, 2000). These conditions have raised concerns about the long-term sustainability of withdrawals from existing wells in the aquifer system. Groundwater withdrawals throughout central and west Maui also have increased and likely will continue to increase to meet future water demands; however, the amount of ground water that is available to meet future demands is uncertain.

Ground-water recharge is one of the most important factors controlling ground-water availability. Two major contributors to ground-water recharge in central and west Maui are agricultural irrigation and rainfall. Significant amounts of surface water from streams within and outside of the study area are diverted for the irrigation of sugarcane and other crops in the study area (fig. 1). Overall irrigation rates in the study area have been steadily decreasing since the 1970s, when large-scale sugarcane plantations began converting to more efficient irrigation methods and reducing the amount of acreage dedicated to sugarcane production (table 1). During the period 1979-2004, sugarcane acreage decreased by about 22 percent in the study area and ceased altogether on the leeward (Lahaina) side of West Maui Mountain. Decreasing irrigation has coincided recently with periods of below-average rainfall, creating the potential for substantially reduced ground-water recharge rates in many areas. 


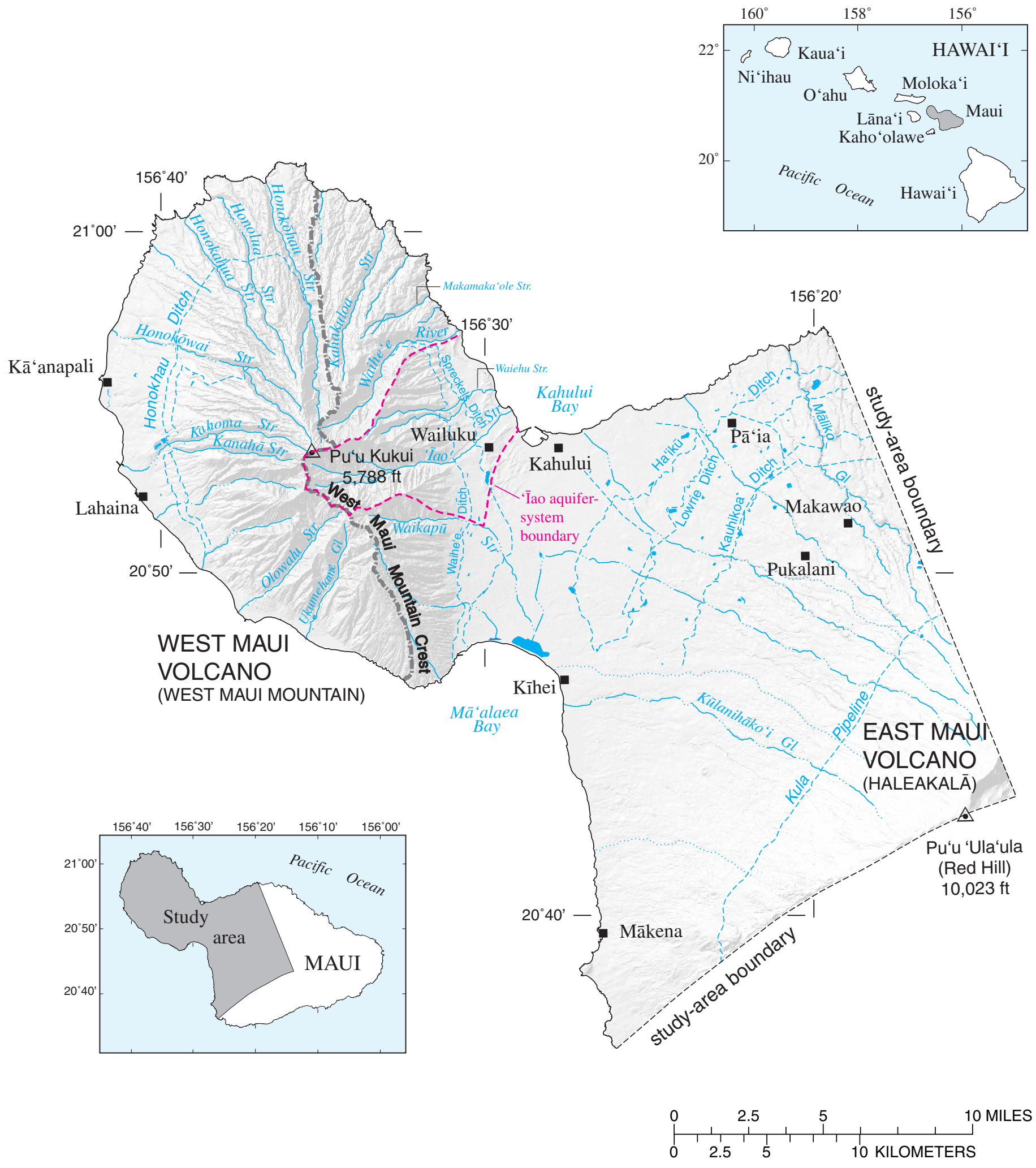

Figure 1. Study area, central and west Maui, Hawai'i. 
In an effort to ensure prudent management of groundwater resources and to plan for sustainable growth on the island, the County of Maui Department of Water Supply (MDWS) entered into a cooperative agreement with the U.S. Geological Survey (USGS) to improve overall understanding of the ground-water flow system and ground-water recharge processes in central and west Maui. The project includes calculation of a water budget to estimate historical recharge and assess the effects of land-use change and rainfall on groundwater recharge.

\section{Purpose and Scope}

This report documents the (1) development of a waterbudget method for calculating daily ground-water recharge in central and west Maui, (2) application of the method to estimate historical ground-water recharge during the period 1926-2004, and (3) application of the method to estimate mean recharge under hypothetical land-use and rainfall conditions. Recharge estimates in this study are compared with those in two previous studies by Shade (1997) and Commission on Water Resource Management (1990), and the sensitivity of the recharge estimates to selected water-budget components and parameters is evaluated. New data generated for this study include about 1 year of climate measurements at three stations on West Maui Mountain (fig. 1) (see app. A).

\section{Previous Investigations}

Although no previous water budget has been calculated for the study area, numerous water budgets have been previously developed for areas within and adjacent to central and west Maui (table 2). The water budgets for the areas listed in table 2 were calculated by using either annual or monthly time steps, as opposed to the daily time step used in this study. The daily time step provides a more realistic simulation of shortduration events, such as daily irrigation and episodic rainfall, than annual or monthly time steps (Izuka and others, 2005).

\section{Acknowledgments}

We thank the Maui Land and Pineapple Co. (ML\&P) for permitting us to install climate stations on their property, and Nobrigas Ranch, Inc., for providing access to a climate-station site. Randy Bartlett, ML\&P Watershed Manager, and his staff, Greg Hansen and Hank Oppenheimer, provided crucial assistance in accessing, constructing, and maintaining these sites. Matt Wong and Phil Teeters of the USGS also provided support in maintaining the climate network. Special-use permits for climate stations were granted through the Hawai ' $i$ Department of Land and Natural Resources' Office of Conservation and Coastal Lands and the Natural Area Reserve System Commission. Wes Nohara (ML\&P), Randall Moore and Lee Ingamells (Hawaiian Commercial and Sugar, Inc.), and Clayton Suzuki (Wailuku Water Co., Inc.) provided important agricultural data and assistance. Kevin Kodama of the National Weather Service provided rainfall data, and Delwyn Oki, Scot Izuka, and Steve Gingerich of the USGS contributed valuable technical assistance during the preparation of this report.

\section{Description of Central and West Maui}

Maui, the second largest island in the Hawaiian Archipelago, is composed of two shield volcanoes. The older volcano, West Maui Volcano (commonly referred to as West Maui Mountain), rises to an altitude of 5,788 ft at $\mathrm{Pu}$ 'u Kukui; and the younger volcano, East Maui Volcano (commonly referred to as Haleakalā), rises to an altitude of $10,023 \mathrm{ft}$ at $\mathrm{Pu}$ 'u 'Ula'ula (Red Hill) (fig. 1). The two volcanoes are connected by an isthmus, as much as 5 mi wide, that is covered with terrestrial and marine sedimentary deposits, (Stearns and Macdonald, 1942). The study area (fig. 1) covers an area of approximately $400 \mathrm{mi}^{2}$, including all of west Maui, the central Maui isthmus, and about a third of east Maui. The east boundary of the study area is approximately formed by the north and southwest rift zones of Haleakalā.

Numerous streams deeply dissect West Maui Mountain, including Waikapū, 'Īao, Kahakuloa, and Honokōhau, and the Waihe'e River (fig. 1). These streams and the Waihe'e River originate from near the summit of West Maui Mountain, where mean annual rainfall exceeds $350 \mathrm{in} / \mathrm{yr}$ (Giambelluca and others, 1986). Within the study area, the surface of Haleakalā is little dissected, and mean annual rainfall over this part of the volcano is generally less than $100 \mathrm{in} / \mathrm{yr}$ (Giambelluca and others, 1986).

\section{Geology}

The geology of Maui was described in detail by Stearns and Macdonald (1942). Some geologic units have been subsequently reclassified, most recently by Sherrod and others (2003). West Maui Mountain consists of a central caldera and two main rift zones that trend northwest and southeast from the caldera. Thousands of dikes - thin, near-vertical sheets of massive, low-permeability rock-are present within the rift zones. The number of dikes increases toward the caldera and with depth. Additional dikes occur outside the general trends of the rift zones, creating a radial pattern of dikes emanating from the caldera (Macdonald and others, 1983). Lava flows emanated from vents in and near the caldera and rift zones.

The central Maui isthmus is formed by nearly flat lying lava flows of Honomanū Basalt, interbedded with consolidated and unconsolidated sedimentary deposits. Beneath the isthmus, the Honomanū Basalt of Haleakalā overlies earthy sedimentary deposits and the older Wailuku Basalt of West Maui Mountain. 
Table 2. Previous water-budget investigations related to central and west Maui, Hawai i $\mathrm{i}$.

\begin{tabular}{ll}
\hline Reference & Area \\
\hline Shade (1999) & East Maui \\
Shade (1997) & 'T̄ao Area \\
Shade (1996) & Lahaina District \\
Austin, Tsutsumi and Associates (1991) & West Maui \\
Commission on Water Resource Management (1990) & Entire island by aquifer system \\
Takasaki (1972) & Central Maui \\
Yamanaga and Huxel (1970) & Wailuku Area \\
Division of Water and Land Development (1970) & Windward west Maui and central Maui \\
Belt, Collins and Associates (1969) & Lahaina District \\
Yamanaga and Huxel (1969) & Lahaina District \\
Caskey (1968) & 'Īao and Waikapū Valleys \\
\hline
\end{tabular}

\section{Surface Water}

Much of the water used to irrigate crops on Maui is diverted from streams, in both east and west Maui, along an extensive system of ditches (fig. 1; Wilcox, 1996). Within the study area, the USGS currently maintains stream gages on the Waihe 'e River and Honokōhau, Kahakuloa, and 'T̄ao Streams. In the past, the USGS has maintained numerous gages on other streams and ditches in the study area (Fontaine, 1996), although the periods of record for some gages are limited.

Perennial streams mainly occur where they intersect the ground-water table of either the freshwater-lens or dikeimpounded ground-water systems, or where rainfall is persistent. Some of the perennial streams in west Maui include the 'Tao, Honokōhau, Kahakuloa, Makamaka'ole, and Waikapū Streams and the Waihe'e River (fig. 1).

\section{Ground Water}

Fresh ground water in the study area occurs mainly in freshwater-lens systems and dike-impounded systems (Yamanaga and Huxel, 1970; Takasaki, 1972; Meyer and Presley, 2000). A freshwater-lens system includes a lens-shaped freshwater body, an intermediate transition zone of brackish water, and underlying saltwater. The thickness of the transition zone depends on the extent of mixing between freshwater and saltwater. Within the study area, freshwater-lens systems are found in dike-free, high-permeability volcanic rocks and sedimentary deposits. A thick wedge of sedimentary deposits that forms a confining unit (caprock) over the high-permeability volcanic rocks near parts of the northeast coast of West Maui Mountain impedes the discharge of water from the freshwaterlens system. Where a coastal confining unit exists, water levels in the freshwater-lens system have exceeded $25 \mathrm{ft}$ above sea level (Meyer and Presley, 2000). Water levels in the freshwater-lens system in areas of west Maui that lack a coastal confining unit generally are lower than $5 \mathrm{ft}$ above sea level, and those in the freshwater-lens system in the isthmus also are generally lower than $5 \mathrm{ft}$ above sea level. Burnham and others (1977) estimated a hydraulic gradient of about $1.6 \mathrm{ft} / \mathrm{mi}$ in the volcanic rocks in the isthmus near Kahului. The salinity of ground water in the isthmus mainly depends on irrigation and withdrawals for agricultural uses (Tenorio and others, 1970; Takasaki, 1972).

Dike-impounded ground-water systems occur near the caldera and rift zones of the volcanoes, where low-permeability dikes have intruded other rocks. Near-vertical dikes generally compartmentalize areas of more permeable volcanic rocks. Dikes impound water to thousands of feet above sea level in the interior of West Maui Mountain.

\section{Historical Agricultural and Urban Land Uses in Central and West Maui}

Land use is important to the estimation of ground-water recharge within a given area because it affects irrigation, runoff, and evapotranspiration. Agricultural and urban land uses are two types of land use that can significantly affect groundwater recharge. Understanding how agricultural and urban land uses change over time is important for estimating historical changes in ground-water recharge. In this study, each type of land use is subdivided into associated land-cover categories. For example, agricultural land use comprises the following land-cover categories: sugarcane, pineapple, macadamia nuts, diversified agriculture, and golf (formerly agriculture) (see table 1). Urban land use comprises the following land-cover categories: residential; commercial; industrial; transportation, communications, and utilities; industrial and commercial complexes; and mixed urban or built-up land. 


\section{Agricultural}

Historically, the principal agricultural land covers in central and west Maui (fig. 1) have been sugarcane, pineapple, macadamia nuts, and diversified agriculture. The plantationscale cultivation of sugarcane (and, to lesser degrees, pineapple and macadamia) has profoundly affected the hydrology of central and west Maui. Since the early 20th century, about 100 billion gal of surface water has been diverted each year (274 $\mathrm{Mgal} / \mathrm{d}$ ) from Maui streams for the irrigation of crops within the study area. More than half of this diverted water, about 59 billion $\mathrm{gal} / \mathrm{yr}(162 \mathrm{Mgal} / \mathrm{d})$, originates outside the study area, in east Maui. Under natural conditions, most diverted surface water would flow to the ocean. Instead, this water has been artificially applied to the plant-soil system, creating a net increase in evapotranspiration and ground-water recharge. Irrigation-enhanced recharge greatly affects the ground-water system within the study area, and assessing historical changes in the amount and spatial distribution of irrigation-enhanced recharge is critical to understanding the ground-water system.

To estimate the historical application of irrigation water, the historical changes in agricultural land use within the study area were estimated (figs. 1, 2). During the period 1979-2004, overall agricultural land use declined 21 percent, while sugarcane acreage decreased 22 percent (fig. 3; table 1). The following is a short summary of agricultural land-use changes on the plantation scale since the mid-19th century.

On the west (Lahaina) side of West Maui Mountain, the Pioneer Mill Co. was a major cultivator of sugarcane from the late 1800s until 1999, when it ceased sugarcane production and was subsequently bought by the Maui Land and Pineapple Co. (ML\&P). ML\&P currently grows pineapple on the northwest slope of West Maui Mountain, where pineapple has a long history of cultivation, and in a small area of former Pioneer Mill Co. sugarcane lands; however, the extent of pineapple cultivation in west Maui has decreased considerably since the late 1990s.

On the east slope of West Maui Mountain, the Wailuku Sugar Co. (currently the Wailuku Water Co.) first began growing sugarcane in 1856. By the mid-1980s, sugarcane was replaced by macadamia trees on the northern extent of the plantation (fig. 2). Additional sugarcane lands were replaced by pineapple by the end of the 1980s. In the 1990s, Wailuku Agribusiness, as the company was then named, continued to diversify away from sugarcane and agriculture altogether. By 2005 , the company had leased the southern extent of the plantation to the Hawaiian Commercial and Sugar Co. (HC\&S), halted macadamia operations, and sold much of its land for residential development.

On the central Maui isthmus, sugarcane has been grown continuously from the late 1800 s until the present by HC\&S and predecessor plantations. ML\&P and several smaller companies currently cultivate pineapple on the lower northwest slope of Haleakalā. Pineapple has been grown in this area for more than a century.
To document the history of agricultural land-use changes in central and west Maui from 1926 to 2004, land-cover and plantation field maps were merged using geographic-information-system (GIS) software. A Geographic Information Retrieval and Analysis System (GIRAS) map of land use and land cover on Maui as of 1976 (State of Hawai 'i, 1976) was used as the base map. We assumed that land cover outside of plantation and urban areas as shown on the 1976 GIRAS map remained the same from 1926 to 2004. Plantation field maps were superimposed on the 1976 GIRAS map. GIS datasets of the plantation field maps from Shade $(1996,1997)$ for Pioneer Mill, Wailuku Agribusiness, and west Maui ML\&P fields were modified with additional information gathered from the plantations (Clayton Suzuki, Wailuku Agribusiness, oral and written communs., 2005; Wes Nohara, ML\&P, oral and written communs., 2005) in an effort to document temporal changes in crop type and field layout. A field map was provided by HC\&S in GIS-shapefile format (Lee Ingamells, written commun., 2005). A paper map of ML\&P pineapple fields in central Maui (Wes Nohara, written commun., 2005) was used to identify which land areas designated as "agricultural land" in the 1976 GIRAS map were used for pineapple cultivation.

\section{Urban}

In urban areas, significant fractions of land are covered by pavement or other impervious surfaces that affect groundwater recharge by enhancing runoff and reducing infiltration. On Maui, urban land area increased steadily throughout the period 1926-2004. We assumed that the urban areas shown on the 1976 GIRAS map were also urban from 1926 through 1984 and that urban land cover remained constant. A combination of the 1976 GIRAS map and a GIS coverage of Maui land cover in 2000 (National Oceanic and Atmospheric Administration, 2000) was used to delineate urban land use and land cover that were assumed to remain constant from 1986 through 2004. Areas on the National Oceanic and Atmospheric Administration (NOAA) map designated as "high-intensity developed" and "low-intensity developed" were superimposed on the GIRAS base map and assigned the GIRAS land-cover categories "residential" and "commercial," respectively. The year 1985 was chosen because the halfway point (1988) between the publication dates of the GIRAS and NOAA datasets (1976 and 2000, respectively) falls within the period 1985-89, one of the six periods for which ground-water recharge is estimated in this study. Use of the 1976 GIRAS map to characterize the extent of urban areas as early as 1926 likely overestimates the amount of urban area in the early years of the study period. 


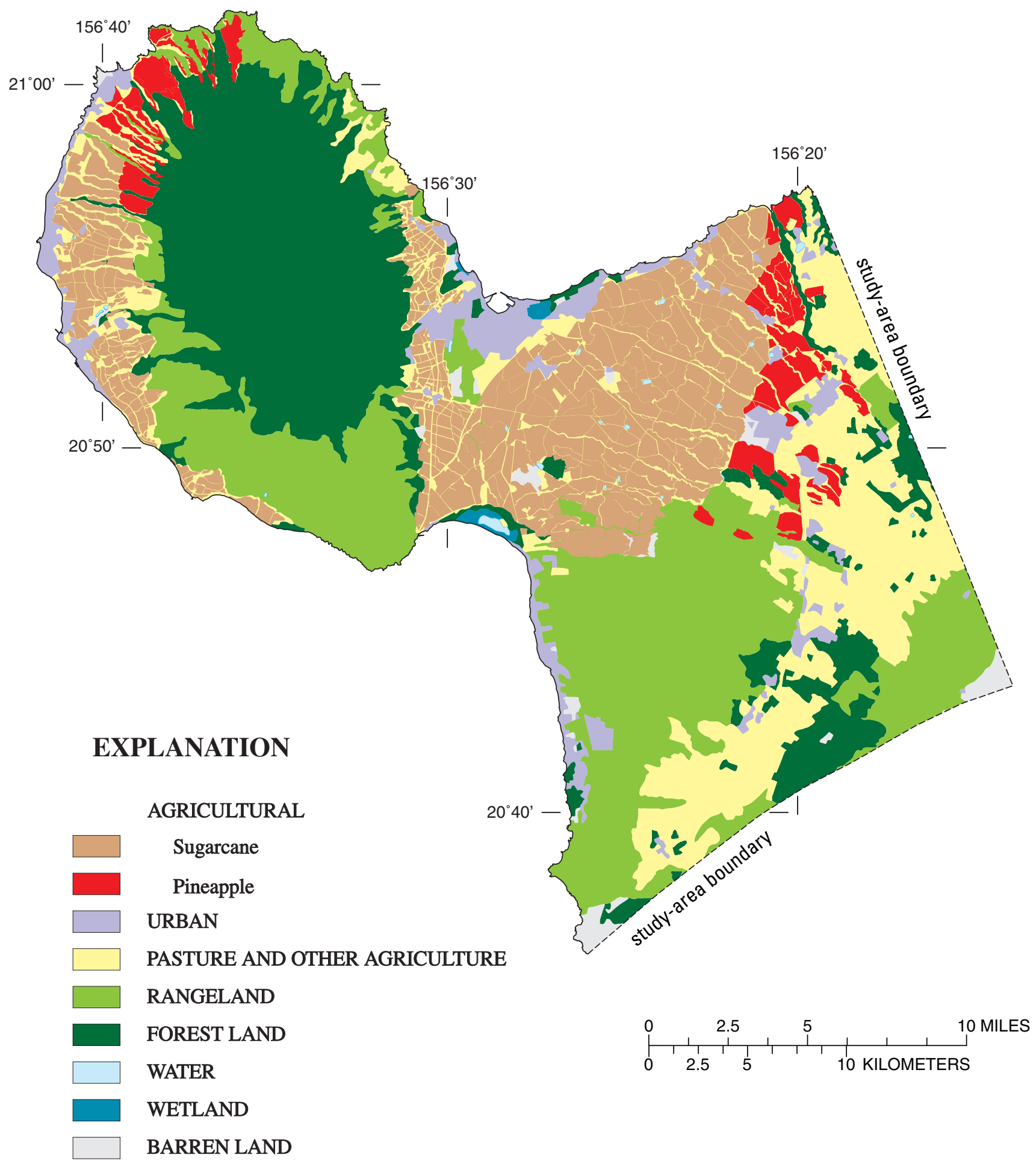

1926-79

Figure 2. Generalized land use for six time periods in central and west Maui, Hawai'i. 


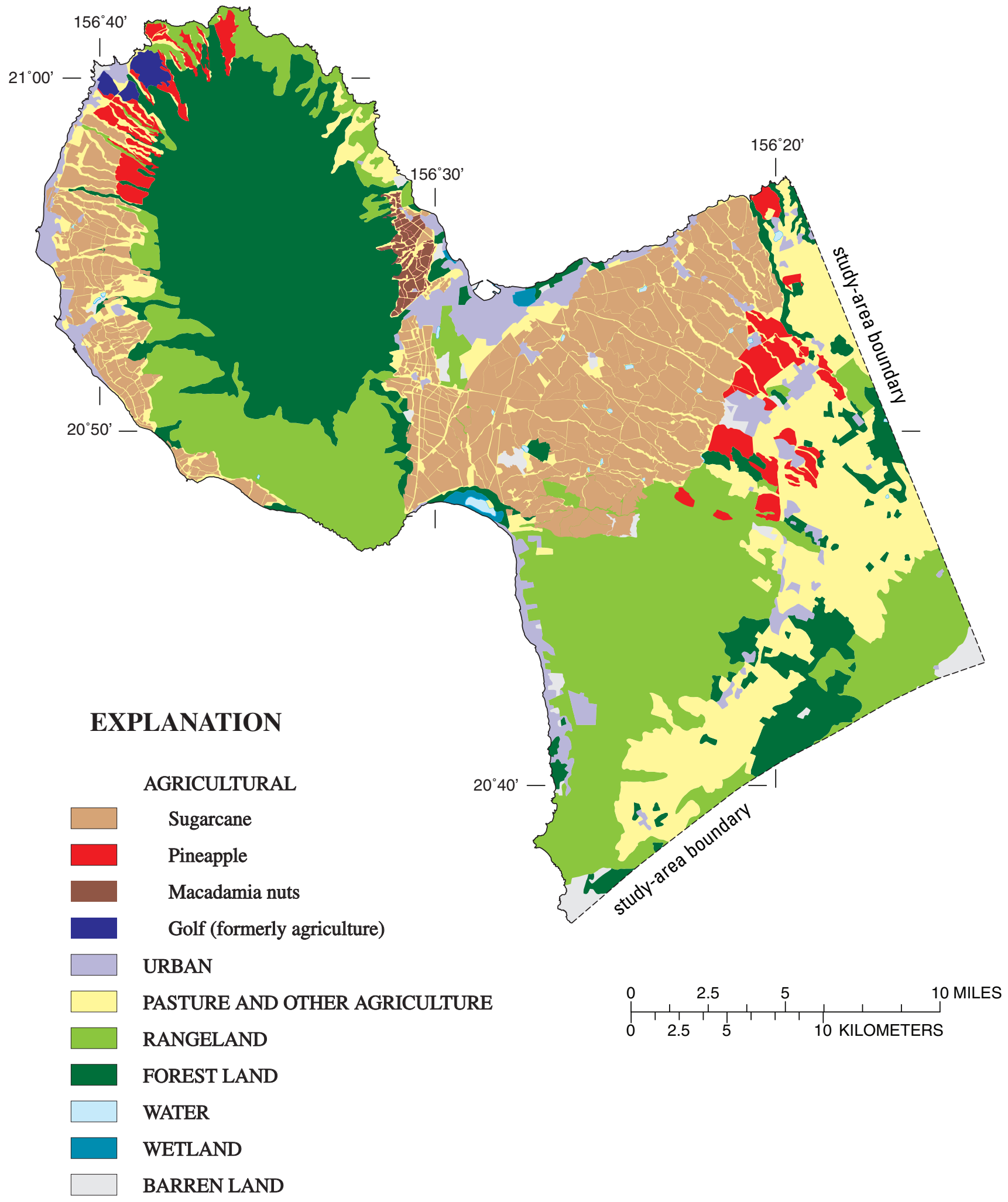

Figure 2. Continued. 


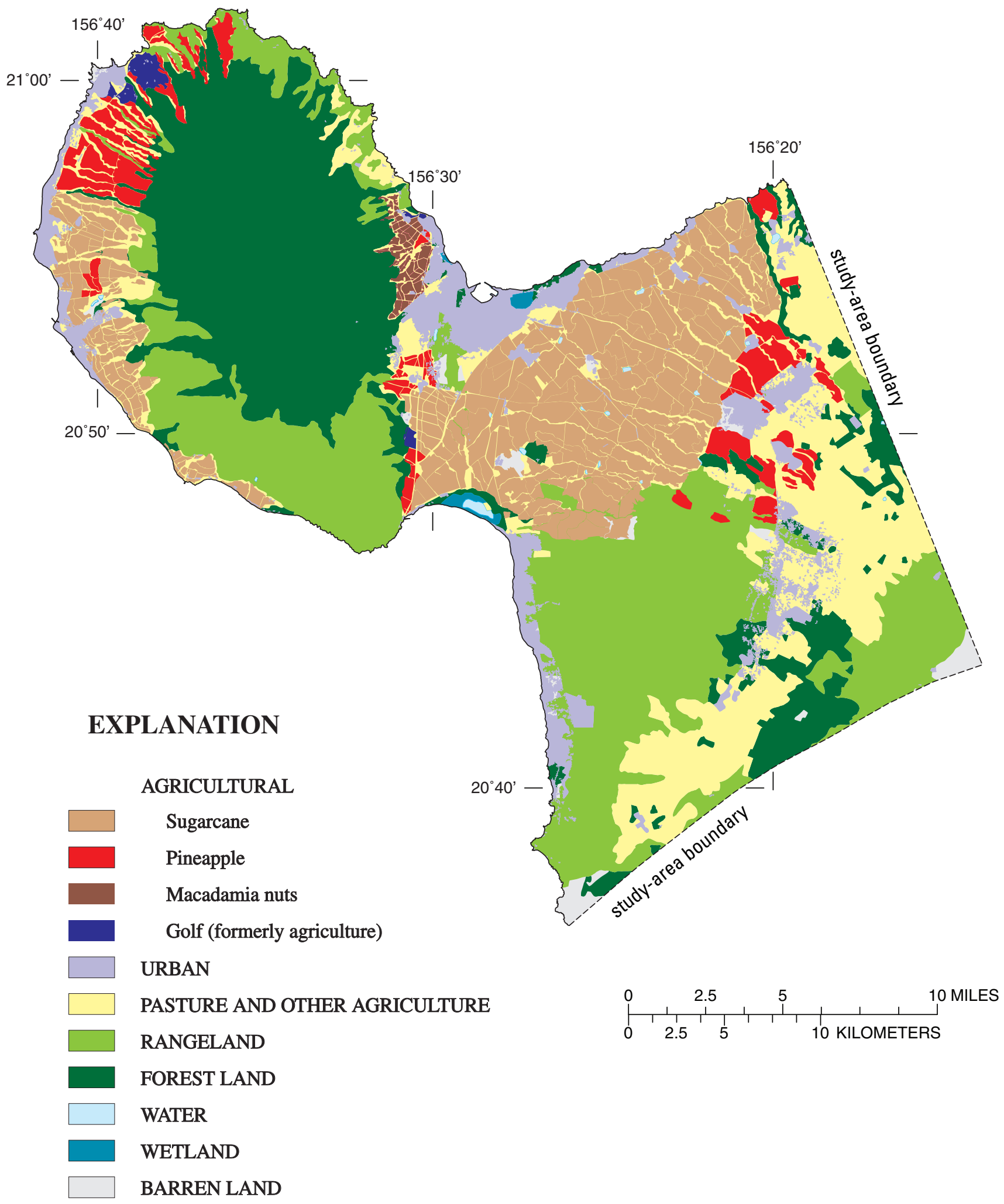

1985-89

Figure 2. Continued. 


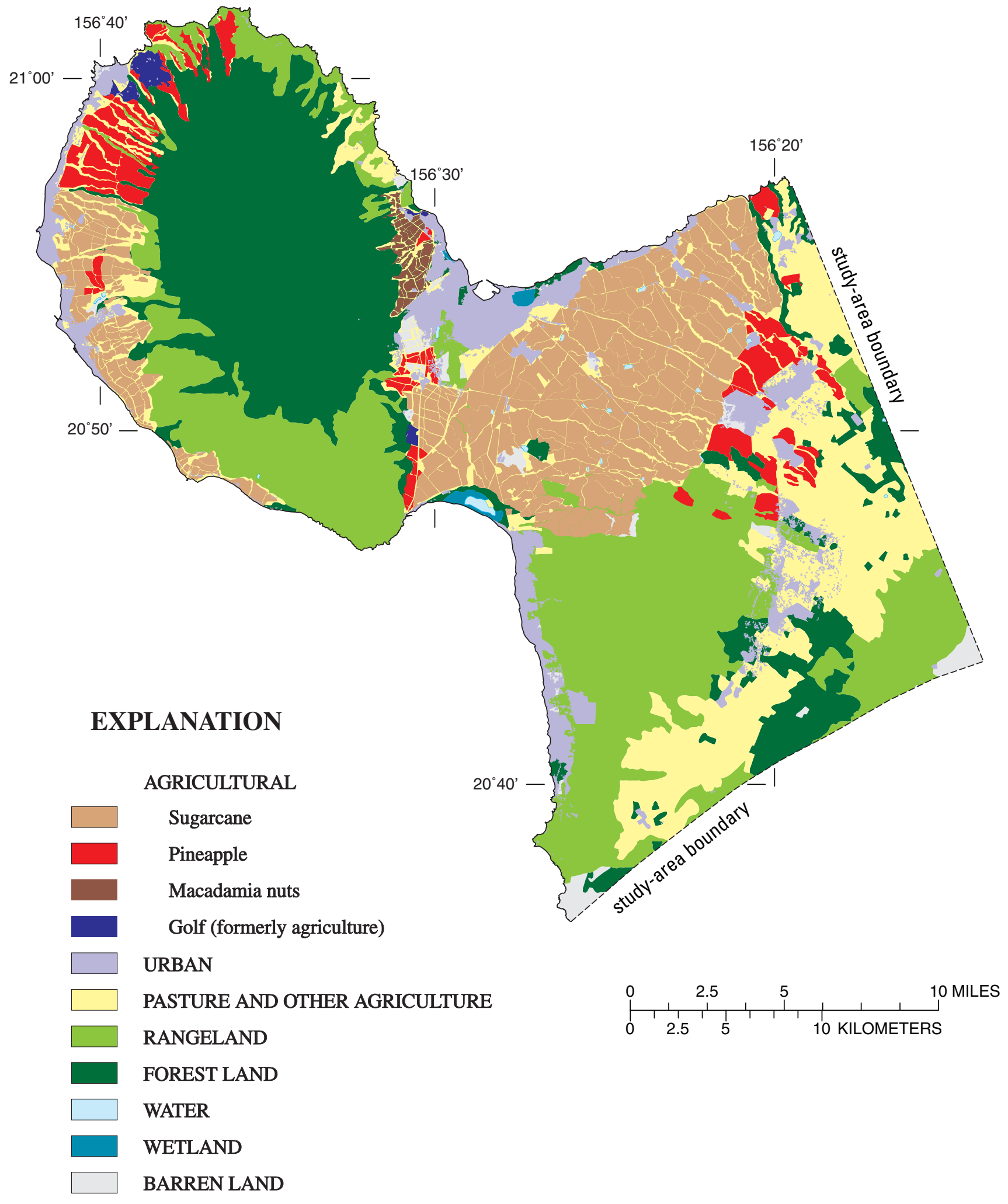

Figure 2. Continued. 


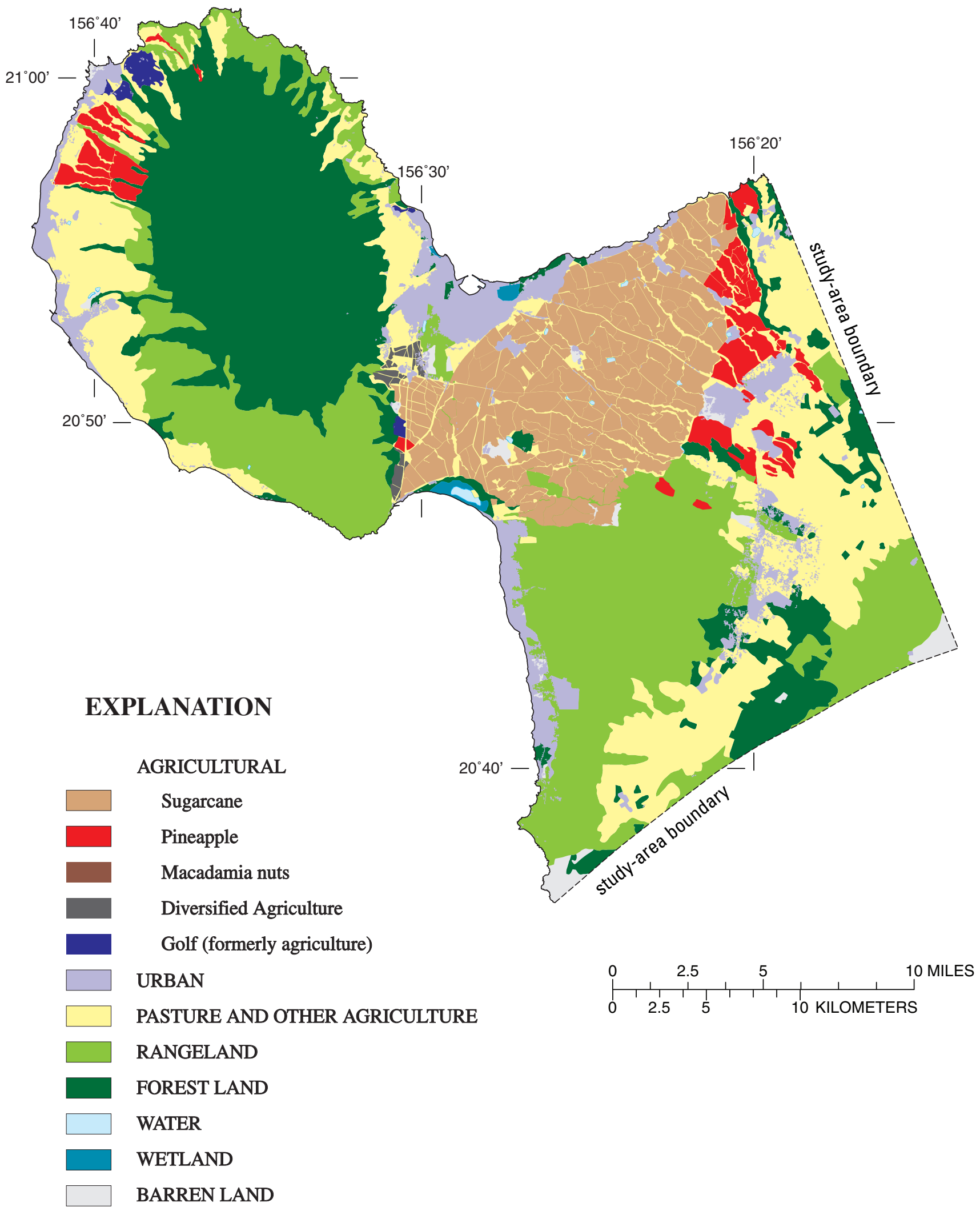

Figure 2. Continued. 


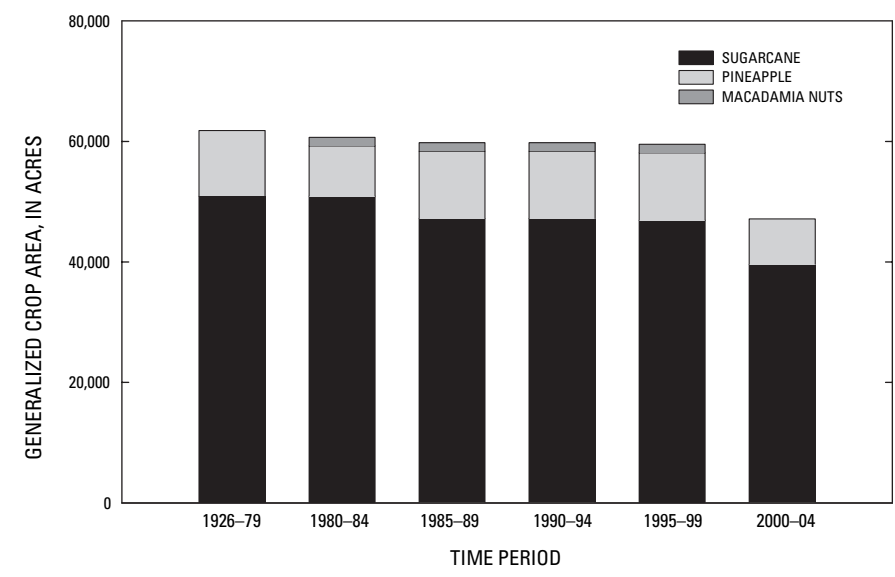

Figure 3. Agricultural land use by crop type for selected time periods from 1926-2004, central and west Maui, Hawai'i.

\section{Water-Budget Method}

\section{Background}

The daily water-budget method used in this study to estimate ground-water recharge is a variant of the mass-balance procedure of Thornthwaite and Mather (1955) that accounts for water entering, leaving, and being stored within the plantsoil system. Water entering the plant-soil system is the sum of rainfall infiltration, irrigation, and fog drip, whereas water leaving the plant-soil system is the sum of evapotranspiration and ground-water recharge (fig. 4). This water-budget method can be used to estimate recharge if the values of other components are known or can be reasonably estimated. Groundwater recharge occurs when more water enters the plant-soil system than can be held within the plant-soil system, given its soil-moisture storage capacity, antecedent moisture content, and moisture losses due to evapotranspiration. Recharge from streambed seepage is not considered in this method. A subsequent USGS ground-water-modeling study of the region is planned to address this subject.

A major assumption of this method concerns rainfall intercepted by vegetation. Interception and subsequent evaporation of rainfall from the surface of vegetation is assumed to be balanced by an equivalent reduction in transpirative demand. Therefore, rainfall-interception factors are not used in this study but, instead, are indirectly accounted for in the evapotranspiration process.

Under natural conditions, the timing of water inflows, water outflows, and changes in soil moisture varies. In this study, the water budget was calculated on a daily basis and then aggregated over longer periods of interest. The daily water budget was calculated by stepping through consecutive days, using the ending soil-moisture storage for the previous day as the initial soil-moisture storage for the current day.

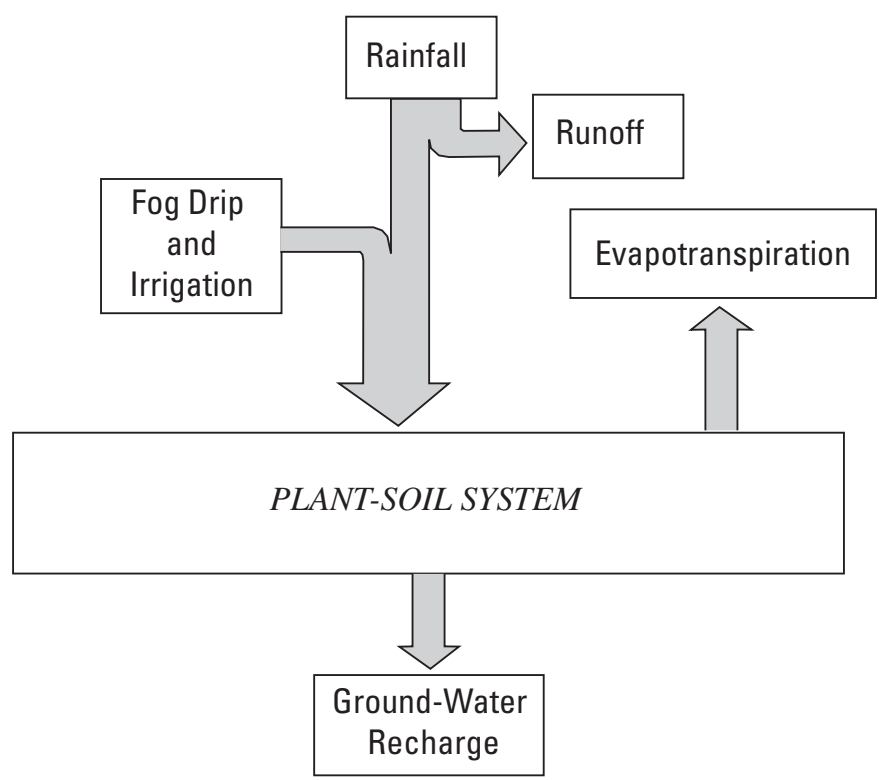

Figure 4. Generalized water-budget flow chart.

\section{Water-Budget Calculations}

Daily ground-water recharge for central and west Maui was calculated by using the daily water-budget method and data that quantify the spatial and temporal distribution of rainfall, fog drip, evaporation, runoff, soil type, irrigation, and land use and land cover. Daily recharge is calculated for areas of homogeneous climatic, hydrologic, soil, and land-use and land-cover properties. The areas of homogeneous properties are generated by merging GIS shapefiles that characterize the spatial and temporal distribution of rainfall, fog drip, pan evaporation, runoff, soil type, land use, and land cover. In the water-budget calculations, water volume is expressed as an equivalent depth of water over an area.

An interim soil-moisture storage, which is the amount of water that enters the soil-water system for the current day plus the amount of water already in the soil from the previous day, is calculated at the start of each day. Interim soil moisture is given by the equation

$$
X_{i}=P_{i}+I_{i}+F_{i}+W_{i}-R_{i}+S_{i-1}
$$

where

$X_{i} \quad=$ interim soil-moisture storage for the current day [L],

$P_{i} \quad=$ rainfall for the current day $[\mathrm{L}]$,

$I_{i} \quad=$ irrigation for the current day $[\mathrm{L}]$,

$F_{i} \quad=$ fog drip for the current day [L],

$W_{i} \quad=$ excess water from the impervious fraction of an urban area distributed over the pervious fraction[L],

$R_{i} \quad=$ runoff for the current day [L], 


$$
\begin{aligned}
& S_{i-1} \quad=\text { soil-moisture storage at the end of the } \\
& \text { previous day }(i-1)[\mathrm{L}] \text {, and } \\
& i=\text { subscript designating "current day." }
\end{aligned}
$$

In urbanized areas, the interim soil-moisture equation includes the factor $W_{i}$, which pertains to the fraction of urban areas that are estimated to be impervious. In nonurban areas where there is no impervious fraction, $W_{i}$ is zero. Urbanized areas are assigned a fraction $(z)$ that is impervious. This fraction is used to separate, from the total rainfall in an urbanized area, a depth of water that is treated computationally as though it fell on an impervious surface. On the basis of this impervious water fraction, some water is subtracted to account for direct evaporation. The rest of the water $\left(W_{i}\right)$ is added to the water budget of the pervious fraction. Thus, for the pervious fraction of an urban area, the total daily water inflow includes an excess of water from the impervious fraction.

For an urbanized area with homogeneous properties, excess water, $W_{i}$, and water storage on the surface of impervious areas were determined by using the following conditions:

$$
X 1_{i}=P_{i}-R_{i}+T_{i-1},
$$

$$
\begin{aligned}
\text { for } X 1_{i} \leq N, \quad W_{i} & =0, \text { and } \\
X 2_{i} & =X 1_{i}, \\
\text { for } X 1_{i}>N, \quad W_{i} & =\left(X 1_{i}-N\right) z /(1-z), \text { and } \\
X 2_{i} & =N,
\end{aligned}
$$

where

$X 1_{i} \quad=$ first interim moisture storage on the surface of impervious area for the current day [L],

$X 2_{i}=$ second interim moisture storage on the surface of impervious area for the current day $[\mathrm{L}]$,

$T_{i-1} \quad=$ water storage on the surface of impervious area at the end of the previous day $(i-1)$ $[\mathrm{L}]$,

$N=$ rainfall interception capacity (maximum amount of water storage on the surface of the impervious area) [L], and

$z=$ fraction of area that is impervious [dimensionless].

The water storage on the surface of the impervious area at the end of the current day, $T_{i}$, is determined from the equation

$$
\begin{aligned}
& \text { for } X 2_{i}>V_{i}, \quad T_{i}=X 2_{i}-V_{i} \text {, and } \\
& \text { for } X 2_{i} \leq V_{i}, \quad T_{i}=0,
\end{aligned}
$$

where

$$
V_{i} \quad=\text { pan evaporation for the current day [L]. }
$$

The next step in the water-budget calculation is to determine the amount of water that will be removed from the soil by evapotranspiration. Actual evapotranspiration is a function of potential evapotranspiration and interim soil moisture $\left(X_{i}\right)$. A vegetated surface loses water to the atmosphere at the potential-evapotranspiration rate if sufficient water is available. Although Penman (1956) defined potential transpiration as "the amount of water transpired in unit time by a short green crop, completely shading the ground, of uniform height and never short of water," in this study the potential-evapotranspiration concept was applied to all vegetated surfaces and was not restricted to a reference short green crop.

At all sites, the potential evapotranspiration was assumed to equal the pan evaporation multiplied by an appropriate vegetation factor (pan coefficient). For soil-moisture contents greater than or equal to a threshold value, $C_{i}$, the rate of evapotranspiration was assumed to equal the potential-evapotranspiration rate. For soil-moisture contents less than $C_{i}$, the rate of evapotranspiration was assumed to occur at a reduced rate that declines linearly with soil-moisture content:

$$
\begin{array}{ll}
\text { for } S \geq C_{i}, & E=(P E)_{i}, \\
\text { for } S<C_{i} \text { and } C_{i}>0, & E=S(P E)_{i} / C_{i},
\end{array}
$$

where

$$
\begin{aligned}
E= & \text { instantaneous rate of evapotranspiration } \\
& {[\mathrm{L} / \mathrm{T}], } \\
(P E)_{i}= & \text { potential-evapotranspiration rate for the } \\
& \text { current day }[\mathrm{L} / \mathrm{T}], \\
S= & \text { instantaneous soil-moisture storage }[\mathrm{L}], \\
& \text { and } \\
C_{i}= & \text { threshold soil-moisture storage } \\
& \text { for the current day below which } \\
& \text { etvapotranspiration is less than the } \\
& \text { potential-evapotranspiration rate }[\mathrm{L}] .
\end{aligned}
$$

The threshold soil-moisture storage, $C_{i}$, was estimated by using the model of Allen and others (1998). In this method, a depletion fraction, $p$, which ranges from 0 to 1 , is defined as the fraction of maximum soil-moisture storage that can be depleted from the root zone before moisture stress causes a reduction in evapotranspiration. The threshold soil moisture, $C_{i}$, is estimated from $p$ by the equation

$$
C_{i}=(1-p) \times S_{m},
$$

where

$$
\begin{aligned}
S_{m}= & \text { soil-moisture storage capacity in the plant } \\
& \text { root zone [L]. }
\end{aligned}
$$

The soil-moisture storage capacity in the plant root zone, $S_{m}$, expressed as a depth of water, equals the plant root depth multiplied by the available water capacity, $\phi$, which is the difference between the volumetric field-capacity moisture content and the volumetric wilting-point moisture content: 


$$
S_{m}=D \times \phi,
$$

where

$$
\begin{aligned}
\mathrm{D}= & \text { plant root depth }[\mathrm{L}], \\
\phi & =\theta_{f c}-\theta_{w p}\left[\mathrm{~L}^{3} / \mathrm{L}^{3}\right], \\
\theta_{f c}= & \text { volumetric field-capacity moisture content } \\
& {\left[\mathrm{L}^{3} / \mathrm{L}^{3}\right], \text { and } } \\
\theta_{w p}= & \text { volumetric wilting-point moisture content } \\
& {\left[\mathrm{L}^{3} / \mathrm{L}^{3}\right] . }
\end{aligned}
$$

Values of $p$ depend on vegetation type and can be adjusted to reflect different potential-evapotranspiration rates. In this study, a $p$ value of 0.65 was used for sugarcane and 0.50 for all other types of vegetation, on the basis of the data of Allen and others (1998).

In the water budget, the evapotranspiration rate may be (1) equal to the potential-evapotranspiration rate for part of the day and less than the potential-evapotranspiration rate for the rest of the day, (2) equal to the potential-evapotranspiration rate for the entire day, or (3) less than the potential-evapotranspiration rate for the entire day. The total evapotranspiration during a day is a function of the potential-evapotranspiration rate $\left[(P E)_{i}\right]$, interim soil-moisture storage $\left(X_{i}\right)$, and threshold soil-moisture content $\left(C_{i}\right)$. By recognizing that $E=-d S / d t$, the total depth of water removed by evapotranspiration during a day, $E_{i}$, was determined as follows:

$$
\begin{aligned}
\text { for } X_{i}>C_{i} \text { and } C_{i} & >0, \\
E_{i} & =(P E)_{i} t_{i}+C_{i}\left\{1-\exp \left[-(P E)_{i}\left(1-t_{i}\right) / C_{i}\right]\right\}, \\
\text { for } X_{i}>C_{i} \text { and } C_{i} & =0, \\
E_{i} & =(P E)_{i} t_{i},
\end{aligned}
$$

for $X_{i} \leq C_{i}$ and $C_{i}>0$,

$$
E_{i}=X_{i}\left\{1-\exp \left[-(P E)_{i} / C_{i}\right]\right\}
$$

and

$$
\text { for } \begin{aligned}
X_{i}=C_{i}, \text { and } C_{i} & =0, \\
E_{i} & =0,
\end{aligned}
$$

where

$$
\begin{aligned}
E_{i}= & \text { evapotranspiration during the day }[\mathrm{L}], \\
t_{i}= & \text { time during which soil-moisture storage is } \\
& \text { above } C_{i}[\mathrm{~T}] . \text { It ranges from } 0 \text { to } 1 \text { day and } \\
& \text { is calculated as follows: }
\end{aligned}
$$$$
\text { for }\left(X_{i}-C_{i}\right)<(P E)_{i}(1 \text { day })
$$$$
t_{i}=\left(X_{i}-C_{i}\right) /(P E)_{i},
$$

and

$$
\begin{aligned}
\text { for }\left(X_{i}-C_{i}\right) & \geq(P E)_{i}(1 \text { day }), \\
t_{i} & =1 .
\end{aligned}
$$

After accounting for runoff (eq. 1), evapotranspiration for a given day was subtracted from the interim soil-moisture storage, and any soil moisture remaining above the maximum soilmoisture storage was assumed to be recharge. Recharge and soil-moisture storage at the end of a given day were assigned according to the following conditions:

$$
\begin{array}{ll}
\text { for } X_{i}-E_{i} \leq S_{m}, & Q_{i}=0, \text { and } \\
& S_{i}=X_{i}-E_{i},
\end{array}
$$

and

$$
\begin{aligned}
\text { for } X_{i}-E_{i}>S_{m}, \quad Q_{i} & =X_{i}-E_{i}-S_{m}, \text { and } \\
S_{i} & =S_{m},
\end{aligned}
$$

where

$$
\begin{aligned}
Q_{i}= & \text { ground-water recharge during the day }[\mathrm{L}], \\
& \text { and }
\end{aligned}
$$

Soil-moisture storage at the end of the current day, expressed as a depth of water, equals the root depth multiplied by the difference between the volumetric soil-moisture content within the root zone at the end of the current day and the volumetric wilting-point moisture content.

$$
S_{i}=D \times\left(\theta_{i}-\theta_{w p}\right),
$$

where

$$
\theta_{i}=\text { volumetric soil-moisture content at the end }
$$
of the current day, $i,\left[\mathrm{~L}^{3} / \mathrm{L}^{3}\right]$.

\section{Rainfall}

Maps of mean monthly rainfall for Maui (Giambelluca and others, 1986) were digitized and used as a basis for the spatial variation and relative distribution of rainfall. The distribution of mean annual rainfall in the study area for the period 1916-83 is mapped in figure 5. Areas between lines of equal monthly rainfall were assigned the average values of the bounding lines. To simulate the temporal variation of rainfall, continuous time series of monthly rainfall data were collected from rain gages within the study area.

Rainfall data were obtained from the Hawai 'i Commission on Water Resource Management (CWRM), the National Climatic Data Center (NCDC), and the National Weather 


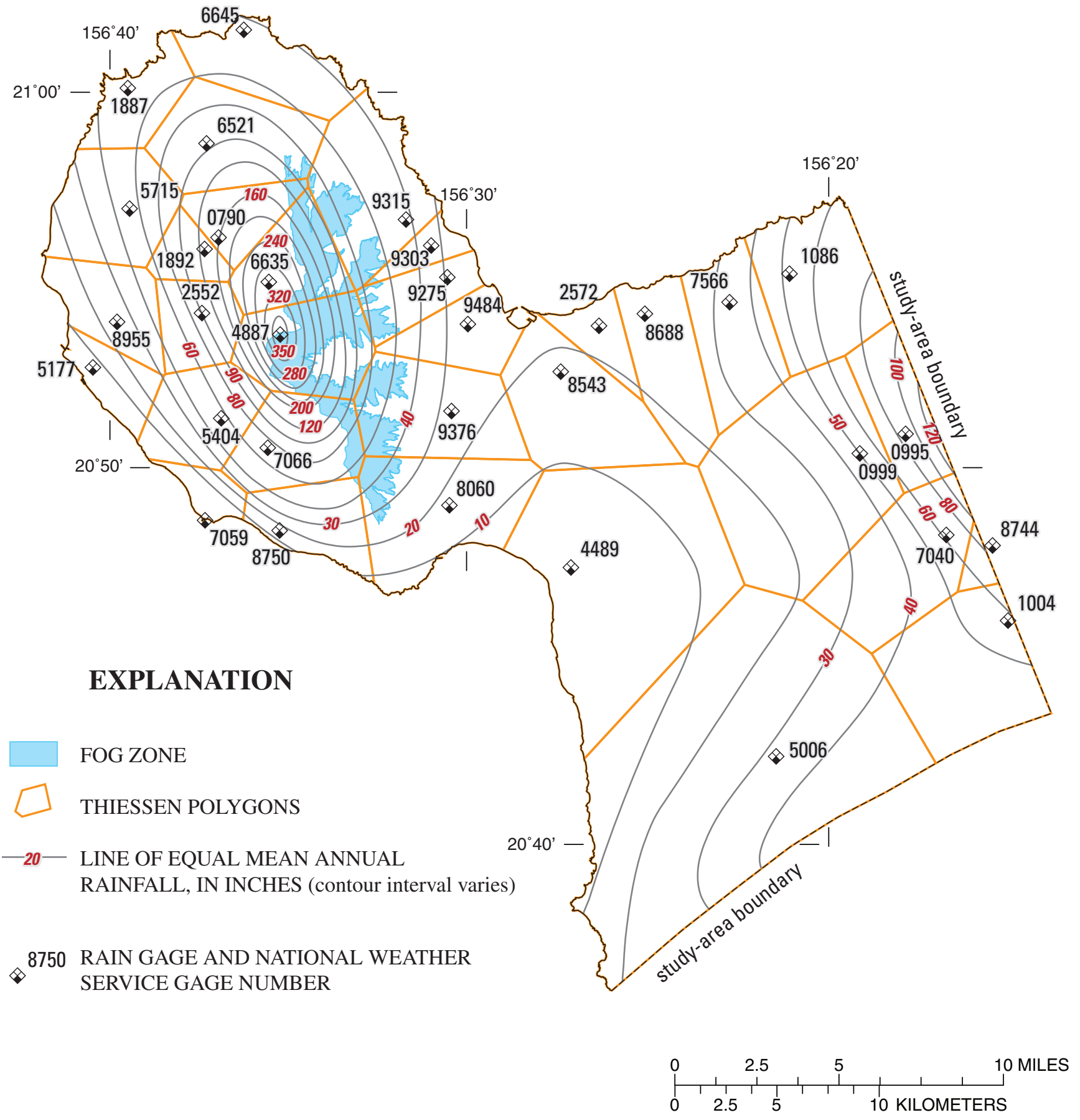

Figure 5. Mean annual rainfall (modified from Giambelluca and others, 1986) and area of fog contribution in central and west Maui, Hawai'i. 
Service (NWS). Rainfall data from CWRM were in the form of monthly rainfall totals through 1986. Rainfall data from the NCDC consisted of daily rainfall from two periods of record: one for the pre-1949 period, and the other for the period 1949-2001 (NCDC, 2002, 2003). Rainfall data from the NWS (Kevin Kodama, written commun., 2005) consisted of monthly totals for the period 2001-5.

A total of 33 rain gages were selected (fig. 5) on the basis of (1) completeness of record and (2) temporal resolution of rainfall measurements. Gages with daily measurements were selected over gages with monthly measurements. In areas where the densities of rain gages were poor, such as the higher-elevation areas of West Maui Mountain, the utilization of rain gages with only monthly measurements was necessary.

Monthly weighting factors, ratios of observed monthly rainfall to mean monthly rainfall, were either directly calculated or estimated for the entire period of record for each gage. Monthly weighting factors were directly calculated if observed data were available; monthly weighting factors were estimated if observed data were missing or unavailable. Mean monthly rainfall values for each gage were obtained from Giambelluca and others (1986). Monthly weighting factors were applied spatially over the study area, using Thiessen polygons drawn around the gages (fig. 5). In this method, rainfall for a given month in a given area equals the weighting factor for that month in that area multiplied by the mean rainfall for that month in that area:

$$
P_{i}=W F_{i} \times \text { Pmean }_{i},
$$

where

$$
\begin{array}{ll}
P_{i} & =\text { the rainfall for month } i[\mathrm{~L}], \\
W F_{i} & =\text { the weighting factor for month } i, \\
& \quad \text { and } \\
\text { Pmean }_{i} & =\text { the mean rainfall for month } i[\mathrm{~L}] .
\end{array}
$$

Most of the rain gages used in the study have periods of missing or incomplete monthly rainfall data. Multiple gages commonly share coinciding periods of missing or incomplete monthly rainfall data, especially for the gages located in the West Maui Mountain area. Without an available measurement of rainfall for a given month, a weighting factor cannot be calculated for that month. To achieve a complete time series of rainfall for the study area, the following method was used to estimate weighting factors for months with unavailable rainfall measurements.

For each month of the year, a linear correlation coefficient, Spearman's rho (Conover, 1999), was calculated between every gage on the basis of the series of calculated weighting factors for that month over the entire period of record, resulting in a set of 12 33-by-33 correlation matrices, or 1 for each month. If a gage had missing or incomplete data for a given month, the weighting factor from the gage with the highest correlation coefficient for that month was used. If data were unavailable for the gage with the highest correlation coefficient, the weighting factor for the gage with the next highest correlation coefficient for that month was used. This process continued until a surrogate weighting factor was determined.

The water-budget method used in this study requires daily rainfall values. Daily rainfall was synthesized by disaggregating the monthly rainfall values, using the method of fragments (for example, Oki, 2002). The method creates a synthetic sequence of daily rainfall from monthly data by imposing the rainfall pattern from a rain gage with daily data. Fragments were created by dividing each daily rainfall measurement for a particular month by the total rainfall for that month, creating a set of fragments for that particular month in which the total number of fragments equaled the number of days in the month. Fragment sets were created for every gage for every month in which complete daily rainfall measurements were available. Fragment sets were grouped by month of the year and by rain gage. The fragment set to be used for a given gage for a given month was selected randomly from among all available sets for that gage for that month of the year. Synthesized daily rainfall for a given month was created by multiplying total rainfall for that month by each fragment in the set.

Rain gages 0790, 6635, 6645, and 7066 (fig. 5) lacked adequate daily-rainfall measurements from which to derive fragment sets, and so these gages were assigned fragment sets from other gages in the same representative rainfall region.

\begin{tabular}{|c|c|c|c|c|c|c|c|}
\hline \multirow{2}{*}{$\begin{array}{l}\text { NWS } \\
\text { gage } \\
\text { number }\end{array}$} & \multirow{2}{*}{$\begin{array}{l}\text { Gage } \\
\text { location }\end{array}$} & \multirow{2}{*}{$\begin{array}{l}\text { Number } \\
\text { of months } \\
\text { with } \\
\text { complete } \\
\text { records }\end{array}$} & \multirow{2}{*}{$\begin{array}{l}\text { Mean monthly } \\
\text { rainfall for } \\
\text { months with } \\
\text { complete } \\
\text { records (in.) }\end{array}$} & \multirow{2}{*}{$\begin{array}{l}\text { Mean monthly } \\
\text { rainfall estimated } \\
\text { using surrogate } \\
\text { WFs (in.) }\end{array}$} & \multicolumn{3}{|c|}{$\begin{array}{c}\text { Error in mean monthly rainfall estimated } \\
\text { using surrogate WFs }\end{array}$} \\
\hline & & & & & $\begin{array}{l}\text { Absolute } \\
\quad \text { (in.) }\end{array}$ & $\begin{array}{l}\text { Relative } \\
\text { (percent) }\end{array}$ & $\begin{array}{l}\text { Root-mean- } \\
\text { square (in.) }\end{array}$ \\
\hline 4489 & Kīhei & 887 & 0.92 & 0.95 & 0.03 & 3 & 0.79 \\
\hline 4887 & $\mathrm{Pu}^{6} \mathrm{u}$ Kukui & 727 & 28.46 & 28.29 & -0.17 & -0.60 & 13.70 \\
\hline
\end{tabular}
Gage 0790 was assigned the gage 1892 fragment set, gage

Table 3. Error in mean monthly rainfall estimated using surrogate weighting factors for selected rain gages, central and west Maui, Hawai'i.

[NWS, National Weather Service; WF, monthly-rainfall weighting factor] 

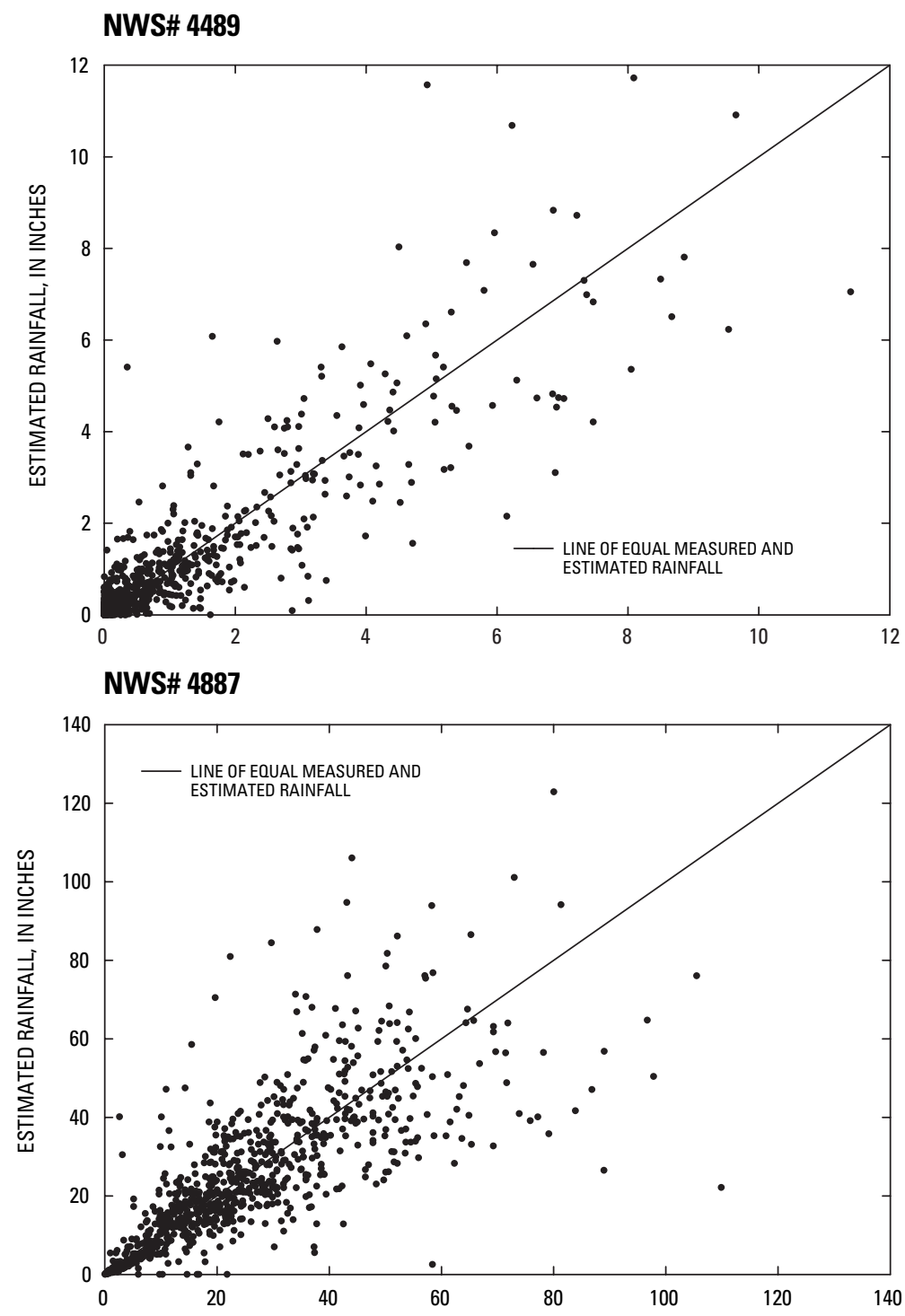

NWS\# 9484

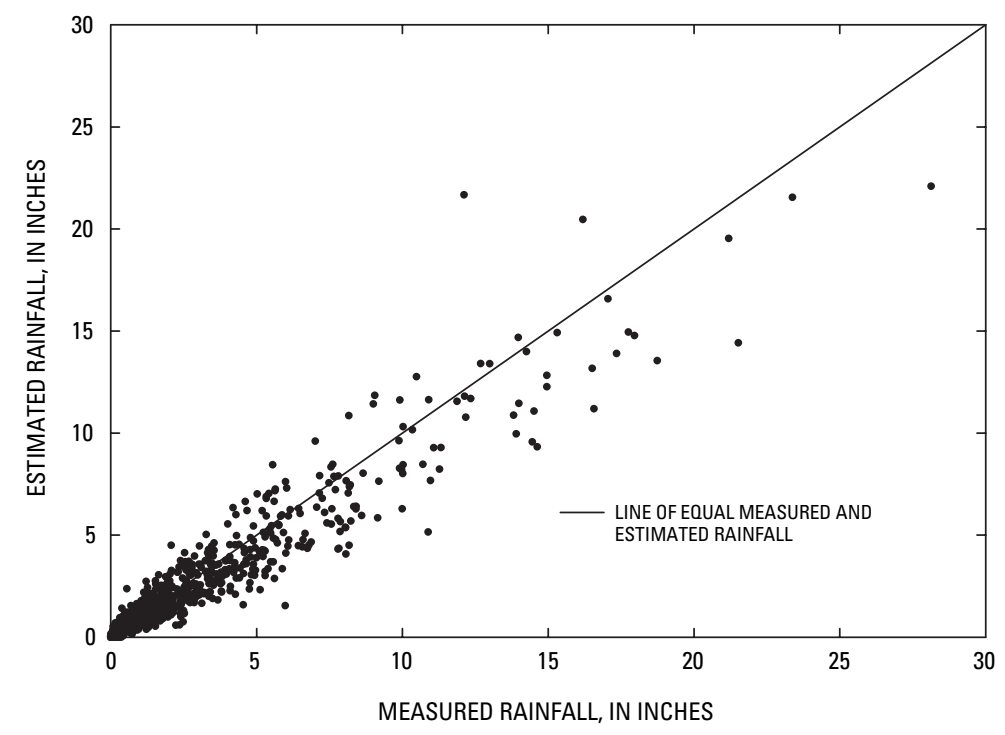

Figure 6. Measured and estimated monthly rainfall at three gages on the Island of Maui, Hawai'i. 
6635 the gage 4887 fragment set, gage 6645 the gage 9315 fragment set, and gage 7066 the gage 5404 fragment set.

To assess the error in estimated monthly rainfall by using the correlation-based procedure when surrogate monthly weighting factors were assigned to gages with missing monthly data, the monthly rainfall calculated with actual weighting factors was compared with the monthly rainfall calculated with surrogate weighting factors at gages 4489, 4887, and 9484 (fig. 6). Gage 4489 (Kīhei) was chosen as representative of low-rainfall sites, gage 4887 (Pu'u Kukui) as representative of high-rainfall sites, and gage 9484 (Wailuku) as representative of medium-rainfall sites and for its location in the 'Tao area. The errors in estimated monthly rainfall calculated for each station are listed in table 3. The absolute value of the relative error was highest for gage 9484 and lowest for gage 4887; the root-mean-square error was highest for gage 4887 and lowest for gage 4489 .

\section{Fog Drip}

"Fog drip" is a term commonly used in Hawai'i to describe cloud water intercepted by vegetation that subsequently drips or flows down branches or stems to the ground. In high-elevation areas of Hawai' $i$ where fog is persistent, fog drip can be a significant component of the water budget. Fog formation in the Hawaiian Islands is generally capped at the base of the trade-wind inversion, which commonly occurs between 5,000- and 10,000-ft elevation (Giambelluca and Schroeder, 1998). Fog has been shown to be persistent at elevations as low as 2,000-3,000 ft on the Island of Hawai ' $\mathrm{i}$ (Juvik and Ekern, 1978). Giambelluca and Nullet (1991) defined the fog zone on the leeward slopes of Haleakalā as extending from about 3,900 to 5,900 ft and estimated a thicker fog zone, at 2,000- to 6,560-ft elevation, along windward slopes.

In water budgets, fog drip is commonly applied spatially in defined fog zones by using a ratio of fog drip to rainfall. One common method of estimating this ratio has been to compare the amount of cloud water collected in a fog gage to the amount of rainfall collected in a rain gage in the same area during concurrent periods. The accuracy of fog-gage measurements is questionable owing to the lack of any established procedure for separating fog deposition from rain deposition and the inherent inability of fog gages to accurately mimic the complexity of forest canopy (Bruijnzeel, 2001; Scholl and others, 2004). Measurement of canopy drip, or throughfall, can be used in place of fog-gage data to calculate fog drip-to-rainfall ratios, although this approach has its limitations, too. Canopy throughfall has considerable spatial variation, and its accurate measurement is highly sensitive to the number and location of measurement points (Bruijnzeel, 2001).

Long-term data on fog drip in central and west Maui are not presently available. A 2-year study conducted concurrently at Auwahi (4,000-ft elevation) on the leeward side of Haleakalā and Waikamoi (6,400-ft elevation) on the windward side of Haleakalā measured canopy throughfall as a percentage of rain at both sites (Scholl and others, 2004). Throughfall was reported as 65 percent of incident rainfall at the leeward site and 119 percent at the windward site. As part of this study, canopy throughfall was measured for a period of 8 months at a site at Kaulalewelewe on the leeward side of West Maui Mountain (see app. A, fig. 8). Data from this site indicate that throughfall is about 58 percent of incident rainfall.

Because this study and that by Scholl and others (2004) indicate that throughfall is less than 100 percent of rainfall at leeward sites on Maui, fog drip was omitted from the water budget in any leeward areas in this study. On the windward side of West Maui Mountain above 2,000-ft elevation (fig. 5 ), fog drip was estimated at 20 percent of rainfall, consistent with the throughfall measured by Scholl and others (2004) at Waikamoi on the windward side of Haleakalā.

\section{Irrigation}

\section{Sugarcane Irrigation}

Historical records of the rate and timing of the application of irrigation water to individual sugarcane fields generally were not maintained by the plantations. Therefore, it was necessary to develop a method to estimate the temporal and spatial distribution of sugarcane irrigation. Two basic approaches were considered: supply-based estimation and demand-based estimation.

Previous water-budget studies in central and west Maui (fig. 1; Shade, 1996, 1997) have used irrigation-system supply (surface-water diversion and ground-water pumpage) as the basis for estimating irrigation. Although large gaps exist in west Maui diversion records, surface-water diversion and ground-water pumpage records for central Maui generally are well maintained and available. In using a supply-based method, it is generally assumed that all water input to the ditch and reservoir system is applied to the fields. A nominal percentage (approx 5-7 percent) is sometimes used to account for seepage and evaporation losses, but normally no accounting of such losses is attempted (Shade, 1996, 1997; Izuka and others, 2005).

Several issues make the application of a supply-based approach problematic for this study. One issue is that spatial distribution of applied irrigation water is not obvious from ditch-flow records. Shade $(1996,1997)$ did not apply any spatial variation to irrigation depths. In practice, sugarcane irrigation is spatially variable (Clayton Suzuki, Wailuku Water Co., oral commun., 2005; Randall Moore and Lee Ingamells, HC\&S, oral communs., 2005). It is dependent on such spatially-varying parameters as rainfall, pan evaporation, and soil characteristics. Another issue is the assumption that all inflows to the system are delivered to the sugarcane fields, or that losses can be estimated simply. In reality, significant amounts of water are lost in ditches and reservoirs through seepage 
and evaporation. An accurate estimate of the amount of water applied to fields would require a complete water balance of the ditch and reservoir system, accounting for variations in reservoir storage. For relatively small areas and small irrigation systems, the issues of spatial variation and system water balances may not be significant (Izuka and others, 2005); however, the irrigated parts of the study area are relatively large, and the ditch and reservoir systems that irrigate central and west Maui plantations are vast, complex networks (Wilcox, 1996). For these reasons, an irrigation-estimation method based on supply was not applied. Average annual ditch flows and ground-water pumpage were used only to assess the upper limit of possible irrigation volume.

Sugarcane-irrigation practices were described in meetings with Randall Moore and Lee Ingamells of HC\&S and Clayton Suzuki of the Wailuku Water Co. The described practices formed the general basis for the sugarcane-irrigation estimation method used in this study. According to HC\&S, sugarcane irrigation is driven by pan-evaporation rates. In this study, irrigation demand was calculated as the difference between pan evaporation and rainfall infiltration. The amount of irrigation applied was calculated as irrigation demand divided by irrigation-method efficiency (table 4), which is the ratio of the volume of water consumed by a crop to the volume of water applied to the field. HC\&S indicated that some of its fields, located above Lowrie Ditch north of Haleakalā Highway and above Ha 'ikū Ditch south of Haleakalā Highway (fig. 1), do not have an adequate supply of irrigation water to meet demand. HC\&S estimated that the supply for these fields is about 80 percent of demand. Accordingly, the daily irrigation of those fields calculated according to the water-demand method described here was multiplied by a factor of 0.8 .

On Maui, sugarcane is typically cultivated in cycles of approximately 24 to 26 months. For simplicity, a cycle of 24 months was selected for this study. Irrigation water is applied for approximately the first 20 months of the cycle, which is termed the "growing period." During the last 40 days or so of the growing period, irrigation is gradually reduced to zero. During the next 2 months, which is termed the "ripening period," no irrigation is applied. After the ripening period, the sugarcane is harvested, and the field lies fallow until the next cycle begins. To simplify modeling of this cycle, no reduction was assessed to irrigation during the last 40 days of the growing period, full irrigation was applied during the first 20 months of the cycle, and the sugarcane field was not irrigated during the last 4 months of the cycle. Plantations plan the cultivation cycles of sugarcane fields such that about half the fields will be harvested in any one year. In the water-budget calculation, sugarcane fields were randomly divided into two groups such that half of each plantation began active cultivation at the start of the simulation and the other half after 12 months into the cycle.

The two major methods of sugarcane irrigation historically used on Maui and throughout Hawai ' $i$ have been furrow and drip. Furrow irrigation was the primary method used before about 1980. The more efficient drip method gradually began replacing furrow irrigation beginning in the mid-1970s (Fukunaga, 1978) and had almost completely replaced furrow irrigation on Maui by the mid-1980s (Clayton Suzuki, oral commun., 2005). To simplify the water-budget calculation, all sugarcane fields were assumed to be furrow irrigated before 1980; for subsequent periods, all fields were assumed to be drip irrigated.

In furrow-irrigated fields, large volumes of water were applied about twice a month to furrows dug in the fields. In drip-irrigated fields, relatively small volumes of water are applied for 2 to 3 consecutive days every week. In the waterbudget calculation, irrigation water was applied to furrowirrigated fields on days 1 and 15 and to drip-irrigated fields on days $1,2,3,8,9,10,15,16,17,22,23,24$, and 28 of each month.

Table 4. Estimated monthly irrigation depths used in the water-budget calculation for central and west Maui, Hawai'i.

\begin{tabular}{|c|c|c|c|c|c|c|c|c|c|c|c|c|}
\hline \multirow{2}{*}{ Land cover } & \multicolumn{12}{|c|}{ Irrigation depth (in.) } \\
\hline & Jan & Feb & Mar & Apr & May & June & July & Aug & Sep & Oct & Nov & Dec \\
\hline All urban categories ${ }^{\mathrm{a}}$ & 0.27 & 0.32 & 0.43 & 0.75 & 0.93 & 1.56 & 2.09 & 1.99 & 1.90 & 1.16 & 0.70 & 0.38 \\
\hline $\begin{array}{l}\text { Diversified } \\
\text { agriculture }\end{array}$ & 1.27 & 1.47 & 1.93 & 1.59 & 1.78 & 1.86 & 2.05 & 2.32 & 2.07 & 2.08 & 1.51 & 1.38 \\
\hline Sugarcane & \multicolumn{12}{|c|}{$\begin{array}{l}\text { Irrigation for month }=(\text { pan evaporation for month }- \text { rainfall for month }+ \text { runoff for month }) / \text { irrigation method } \\
\text { efficiency }\end{array}$} \\
\hline Pineapple & \multicolumn{12}{|c|}{ Irrigation for month $=4.3$ in. ${ }^{b}-$ rainfall for month + runoff for month } \\
\hline
\end{tabular}

${ }^{\text {a }}$ Irrigation depths modified from Giambelluca (1983). See table 8 for complete list of urban land-cover categories.

${ }^{\mathrm{b}}$ Value is based on $1 \mathrm{in} /$ week. 
For Hawai 'i, estimates of furrow-irrigation efficiency range from 0.30 to 0.70 , and of drip-irrigation efficiency from 0.80 to 0.95 (Fukunaga, 1978; Izuka and others, 2005). HC\&S uses estimates of 0.50 for furrow efficiency and 0.80 for drip efficiency (Randall Moore and Lee Ingamells, oral communs., 2005); these values of irrigation efficiency were used in the water-budget calculation.

Because of the paucity of sugarcane field-irrigation data, analysis of the accuracy of the irrigation-estimation method used in this study was difficult. For the period 1926-79, using the irrigation-estimation method the estimated average annual sugarcane-irrigation is $114 \mathrm{in}$. (437 Mgal/d) in the study area. The average sum of stream diversions and ground-water pumpage for irrigation purposes during this period was about $501 \mathrm{Mgal} / \mathrm{d}$ (Belt, Collins and Associates, 1969; Yamanaga and Huxel, 1970; Takasaki, 1972). If water-system losses occurred at the commonly assumed 7-percent rate (Randall Moore, HC\&S, oral commun., 2005), then about $466 \mathrm{Mgal} / \mathrm{d}$ was available for irrigation, or about 7 percent more irrigation water than was simulated by the irrigation-estimation method. After the 1970s, surface-water diversion data for west Maui was poorly maintained, and so this method of comparison is impractical for more recent periods.

One point of comparison for more recent periods was the water-balance data supplied by HC\&S for Field 213 on the north side of the plantation (Lee Ingamells, written commun., 2005). From this dataset, an average sugarcane irrigation for the period 1995-2004 was estimated. The average irrigation calculated by the irrigation-estimation method of this study was 5 percent greater than that estimated from HC\&S Field 213 data.

\section{Other Irrigation}

A similar demand-based approach was used to simulate irrigation of Maui's two other major crops, pineapple and macadamia nuts. Wes Nohara of ML\&P and Clayton Suzuki of the Wailuku Water Co. were interviewed concerning pineapple-irrigation practices, and pineapple- and macademia-irrigation practices, respectively. In the water-budget calculation, irrigation timing and monthly rates (table 4) for pineapple and macadamia nuts were based on information obtained in these interviews. Irrigation was uniformly distributed among each day of the month. On Maui, irrigation of pineapple did not begin until about 1980, and so no irrigation was applied to pineapple fields in the water-budget calculation before 1980.

Monthly irrigation of former plantation lands converted to golf courses was estimated from water-use reports and other documentation supplied by the Wailuku Water Co. (Clayton Suzuki, written commun., 2005). It was assumed that all irrigation for the golf courses was supplied by the sources documented in the water-use report. Diversified agriculture fields, which occupy relatively small areas, were assumed to have been irrigated exactly the same as golf courses. Monthly urban-irrigation (lawn-sprinkling) depths used in this study were calculated by Giambelluca (1983) for southern O`ahu (table 4). For golf courses, diversified agriculture fields, and urban areas, irrigation was uniformly distributed among each day of the month.

\section{Runoff}

In this study, "runoff" is synonymous with the term "direct runoff" and is defined as the fraction of rainfall that does not contribute to net root-zone moisture. Direct runoff consists of overland surface flow and interflow (water that flows in the shallow subsurface and is eventually discharged to a stream or other surface-water body).

To assist in runoff analysis, the study area was divided into four runoff regions on the basis of hydrogeologic and physiographic features (fig. 7). This approach is similar to that used by Shade $(1996,1997,1999)$. Regions 1 and 2, the dike-impounded ground-water regions of West Maui Mountain, are characterized by mountainous, steeply sloping, highly eroded terrain with large areas of exposed rock. Region 1 is west (leeward), and region 2 is east (windward), of the West Maui Mountain crest. Most surface-water diversion occurs at the downstream extent of the dike-impounded regions to take full advantage of the high base flow (ground-water discharge into a stream) and springs that are characteristics of the dikeimpounded regions. Thus, regions 1 and 2 contain drainage basins with streamflow-gaging records useful for calculating runoff. Regions 3 and 4, the freshwater-lens ground-water regions of West Maui Mountain and the west (leeward) slope of Haleakalā, respectively, are characterized by more gently sloping, less-eroded terrain relative to regions 1 and 2.

In regions 1 and 2, direct runoff was calculated for drainage basins with long-term, continuous stream-gaging measurements (table 5) as the fraction of streamflow not derived from ground water. The hydrograph-separation program of Wahl and Wahl (1995) was used to separate the ground-water, or base-flow, component of streamflow from the direct-runoff component. This computerized method removes much of the subjectivity associated with manual hydrograph-separation techniques, and provides repeatable results if the two input parameters required by the method are held constant. The method is commonly used by the USGS in Hawai ' $i$ (for example, Fontaine, 2003; Izuka and others, 2005). In the hydrograph-separation method, the two parameters are $N$ (number of days) and $f$ (turning-point test factor). The method divides the daily streamflow data into non-overlapping periods, each $N$ days long, and determines the minimum flow in each period. If the minimum flow within a period is less than $f$ times the minimums of both adjacent periods, the centralperiod minimum is made a pivot (or turning point) on the base-flow hydrograph. Straight lines drawn on semilogarithmic paper between turning-point discharge plotted versus the central time of the corresponding period define the base-flow hydrograph. The recommended $f$ value, 0.9 (Wahl and Wahl, 1995), was used for all base-flow separations. Conceptually, the variable $N$ represents the number of days after a storm 


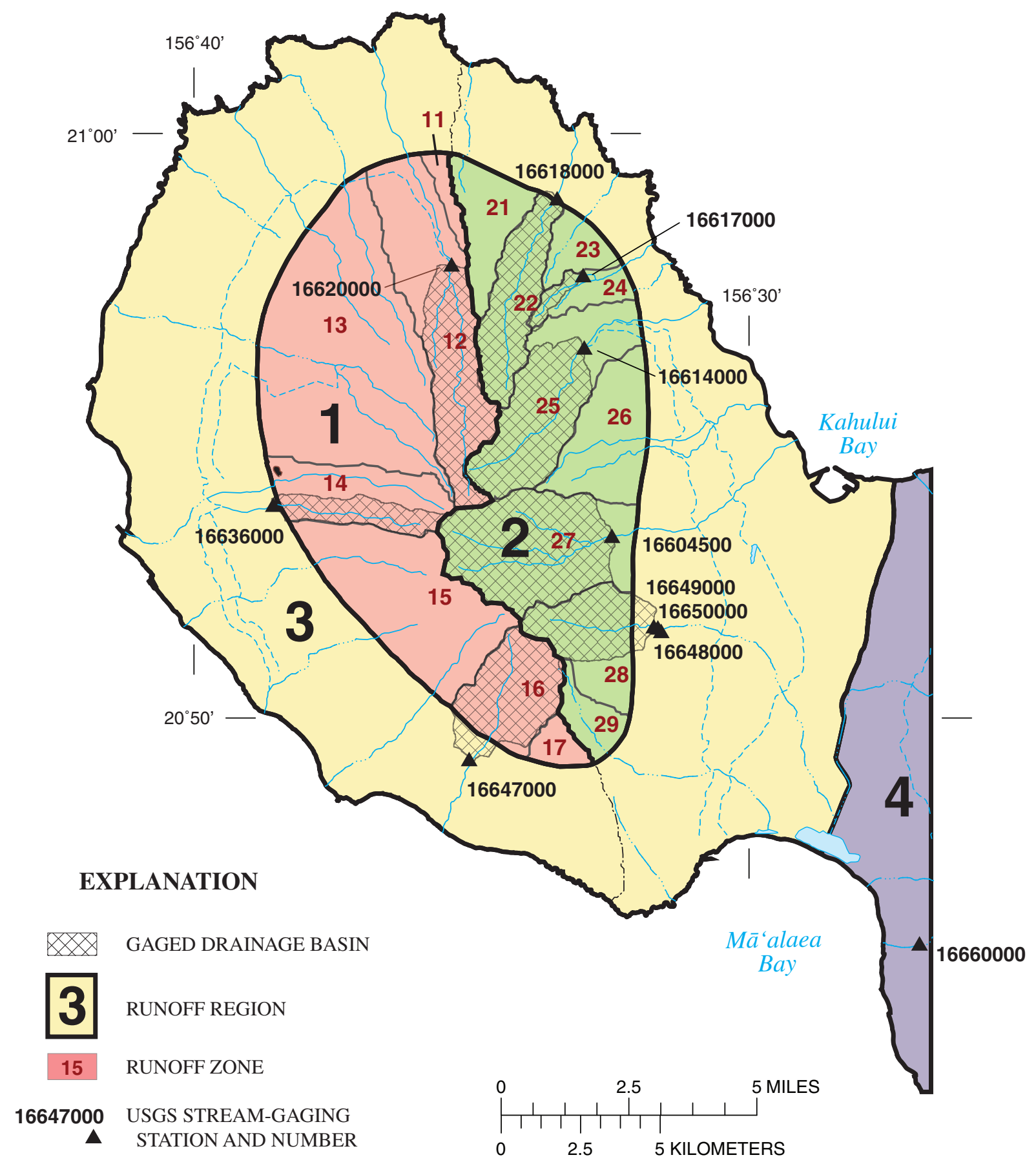

NOTE: THE PORTION OF THE STUDY AREA NOT SHOWN ON THIS MAP LIES WITHIN RUNOFF REGION 4.

Figure 7. Runoff regions and runoff zones used in the water-budget calculation for central and west Maui, Hawai'i. 
Table 5. USGS stream-gaging stations used to calculate ratios of runoff to rainfall for this study.

[N/A, not applicable]

\begin{tabular}{|c|c|c|c|c|}
\hline $\begin{array}{l}\text { Runoff } \\
\text { zone }\end{array}$ & $\begin{array}{l}\text { Gaging- } \\
\text { station } \\
\text { number }\end{array}$ & $\begin{array}{l}\text { Gaging-station } \\
\text { location }\end{array}$ & $\begin{array}{l}\text { Periods of record used in } \\
\text { calculation }\end{array}$ & $\begin{array}{l}\text { Number of days, } \mathrm{N} \text {, used in } \\
\text { determining minimum flows } \\
\text { in the hydrograph- } \\
\text { separation program }\end{array}$ \\
\hline \multicolumn{5}{|c|}{ Unregulated streams and river } \\
\hline 12 & 16620000 & Honokōhau Stream & 1913-20, 1922-88, 1990-2004 & 4 \\
\hline 14 & 16636000 & Kanahā Stream & $1916-25,1926-32$ & 3 \\
\hline 16 & 16647000 & Ukumehame Stream & $1911,1913-19$ & N/A \\
\hline 22 & 16618000 & Kahakuloa Stream & $1939-43,1947-70,1975-2004$ & 4 \\
\hline 24 & 16617000 & Makamaka'ole Stream & $1939-52$ & 3 \\
\hline 25 & 16614000 & Waihe'e River & $1983-2005$ & 3 \\
\hline 27 & 16604500 & 'T̄ao Stream & 1983-2004 & 4 \\
\hline \multicolumn{5}{|c|}{ Regulated streams and diversions } \\
\hline \multirow[t]{3}{*}{28} & 16650000 & Waikapū Stream & $1910-12,1913-17$ & N/A \\
\hline & 16649000 & Pālolo Ditch & $1910-12,1913-17$ & N/A \\
\hline & 16648000 & South Side Waikapū Ditch & $1910-12,1913-17$ & N/A \\
\hline
\end{tabular}

before direct runoff generally ceases (Fontaine, 2003). The $N$ value is determined separately for each streamflow gage. To determine the $N$ value for each streamflow gage, base flow was first estimated for each $N$ value between 1 and 10 days. The ratio of base flow to total flow during the period of $N$ days, or the base-flow index, was then plotted against $N$. At first, increasing $N$ generally causes a significant drop in estimated base flow because the proportion of direct runoff in the total flow is reduced as the effect of storm events dissipate during the longer time period. At a critical $N$ value, the proportion of direct runoff will be negligible, and estimated base flow will drop only slightly, becoming essentially linear with increasing $N$. This critical $N$ value was then used to estimate base flow for the streamflow gage being analyzed (table 5).

For Ukumehame Stream (gaging sta. 16647000), not enough streamflow data were available to properly use the hydrograph-separation program. To separate base flow from the total flow hydrograph, a flow-duration curve for '⿳亠丷厂ao Stream (gaging sta. 16604500) was calculated from which the exceedance frequency of base flow was calculated (see, for example, Searcy, 1959). The base-flow exceedance frequency of 'Tao Stream, 71 percent, was then applied to the monthly flow-duration curves of gaging station 16647000 to estimate monthly base flow for Ukumehame Stream.

To accurately calculate base flow with the hydrographseparation program, no controls (water diversions, water additions, or reservoirs) should exist upstream of the continuous stream-gaging station. On Waikapū Stream, two surface-water diversion ditches exist upstream of gaging station 16650000 (fig. 7), at Pālolo Ditch and South Side Waikapū Ditch. The diversions are recorded at gaging stations 16649000 and 16648000, respectively. Concurrent records of all three continuous-gaging stations exist for the periods 1910-12 and 1913-17, and a composite hydrograph was constructed for these periods. The exceedance frequency of base flow for 'T̄ao Stream, 71 percent, was then applied to the monthly flow-duration curves of the Waikapū Stream composite hydrograph to estimate monthly base flow for Waikapū Stream above gaging station 16650000.

Mean monthly direct runoff for a drainage basin was divided by the long-term mean monthly rainfall over that basin (Giambelluca and others, 1986) to calculate monthly runoffto-rainfall ratios (table 6). Because of the relative short periods from which monthly direct runoff was calculated for Ukumehame and Waikapū drainage basins, mean monthly rainfall for the corresponding time of available streamflow data was used for those basins instead of the long-term mean.

Regions 1 and 2 were subdivided into runoff zones on the basis of watersheds defined by the State of Hawai ' 1 (2005). Zones listed in table 6 were assigned runoff-to-rainfall ratios on the basis of the methods described above. Zones not listed in table 6 were assigned the average of the runoff-to-rainfall ratios for adjacent zones within the same runoff region.

For region 3, runoff-to-rainfall ratios were assigned by extending the method used by Shade (1996) for the Lahaina area to the entire region. Shade (1996) derived annual runoffto-rainfall ratios on the basis of data from comparable areas

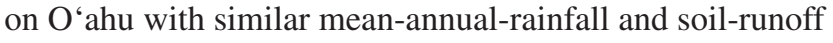
characteristics.

For region 4, in which no perennial streams exist, monthly runoff-to-rainfall ratios calculated by Shade (1999) for the west slope of Haleakalā were used. These ratios were 
calculated using the streamflow data from gaging station 16660000 (fig. 7) on Kūlanihāko'i Gulch (fig. 1), an ephemeral stream with no base flow. Mean monthly streamflow was divided by mean monthly rainfall to calculate the ratios.

\section{Evapotranspiration}

Evapotranspiration is a combination of two practically indistinguishable processes in the plant-soil system whereby water is lost from the surface and near-surface of the soil through evaporation and from the plant through transpiration (Allen and others, 1998). The maximum rate at which evapotranspiration can remove water from a plant-soil system, if soil-moisture stress is nonlimiting, is termed "potential evapotranspiration" (Giambelluca, 1983). The actual rate of evapotranspiration becomes less than the potential rate with the onset of soil-moisture stress. As soil dries, capillary and adsorptive forces bind the remaining water to the soil matrix more strongly, reducing water flow to roots. Soil-moisture stress occurs when the decreasing water flow to the root system induces a response in the plant to slow transpiration and prevent desiccation. The threshold moisture content at which a plant begins to react to soil drying varies with the type of plant. Calculating the actual evapotranspiration rate involves first determining potential evapotranspiration and then estimating a relation between the ratio of actual evapotranspiration to potential evapotranspiration and available soil moisture (Giambelluca, 1983).

Table 6. Monthly and annual runoff-to-rainfall ratios for runoff zones, central and west Maui, Hawai'i.

[See figure 7 for locations of runoff zones and runoff regions]

\begin{tabular}{|c|c|c|c|c|c|c|c|c|c|c|c|c|c|}
\hline $\begin{array}{c}\text { Runoff } \\
\text { zone }\end{array}$ & Jan & Feb & Mar & Apr & May & June & July & Aug & Sep & Oct & Nov & Dec & Avg. \\
\hline \multicolumn{14}{|c|}{ Monthly runoff-to-rainfall ratios for runoff region 1} \\
\hline 12 & 0.25 & 0.26 & 0.25 & 0.31 & 0.32 & 0.28 & 0.31 & 0.32 & 0.22 & 0.25 & 0.32 & 0.29 & 0.28 \\
\hline 13 & 0.23 & 0.23 & 0.23 & 0.29 & 0.23 & 0.22 & 0.29 & 0.29 & 0.20 & 0.20 & 0.28 & 0.29 & 0.25 \\
\hline 15 & 0.12 & 0.12 & 0.13 & 0.17 & 0.15 & 0.25 & 0.23 & 0.20 & 0.16 & 0.14 & 0.15 & 0.18 & 0.17 \\
\hline 16 & 0.04 & 0.05 & 0.05 & 0.06 & 0.15 & 0.32 & 0.19 & 0.14 & 0.14 & 0.13 & 0.06 & 0.06 & 0.12 \\
\hline 17 & 0.04 & 0.05 & 0.05 & 0.06 & 0.15 & 0.32 & 0.19 & 0.14 & 0.14 & 0.13 & 0.06 & 0.06 & 0.12 \\
\hline \multicolumn{14}{|c|}{ Monthly runoff-to-rainfall ratios for runoff region 2} \\
\hline 24 & 0.65 & 0.44 & 0.95 & 0.55 & 0.53 & 0.43 & 0.50 & 0.67 & 0.60 & 0.59 & 0.55 & 0.87 & 0.61 \\
\hline 25 & 0.26 & 0.19 & 0.29 & 0.25 & 0.23 & 0.36 & 0.38 & 0.27 & 0.30 & 0.23 & 0.26 & 0.20 & 0.27 \\
\hline 26 & 0.37 & 0.27 & 0.35 & 0.38 & 0.31 & 0.48 & 0.43 & 0.30 & 0.32 & 0.33 & 0.32 & 0.31 & 0.35 \\
\hline 27 & 0.47 & 0.35 & 0.42 & 0.52 & 0.39 & 0.60 & 0.48 & 0.33 & 0.33 & 0.43 & 0.38 & 0.42 & 0.43 \\
\hline 28 & 0.13 & 0.18 & 0.11 & 0.19 & 0.42 & 0.87 & 0.37 & 0.27 & 0.44 & 0.23 & 0.18 & 0.19 & 0.30 \\
\hline 29 & 0.13 & 0.18 & 0.11 & 0.19 & 0.42 & 0.87 & 0.37 & 0.27 & 0.44 & 0.23 & 0.18 & 0.19 & 0.30 \\
\hline \multicolumn{14}{|c|}{ Monthly runoff-to-rainfall ratios for runoff region 4} \\
\hline & 0.01 & 0.01 & 0.05 & 0.01 & 0.01 & 0.00 & 0.01 & 0.00 & 0.01 & 0.00 & 0.02 & 0.01 & 0.01 \\
\hline \multicolumn{14}{|c|}{ Annual runoff-to-rainfall ratios for runoff region 3} \\
\hline
\end{tabular}




\section{Potential Evapotranspiration}

Potential evapotranspiration is controlled by prevailing atmospheric conditions (solar radiation, air temperature, humidity, and wind) and land-cover characteristics (reflectance, roughness, and plant physiology) (Giambelluca, 1983). Potential-evapotranspiration data for Hawai ' $i$ are fairly sparse; however, a significant volume of pan-evaporation data has been collected over many years by sugar plantations. Measurements of pan evaporation, though highly correlated with atmospheric conditions, are poorly correlated with land-cover characteristics. To account for land-cover characteristics, previous studies calculated pan coefficients for Hawai ' $i$ on the basis of vegetative cover on Hawai ' 1 (Ekern and Chang, 1985; Oki, 2002; Izuka and others 2005). A pan coefficient is an empirically derived ratio of potential evapotranspiration to pan evaporation. Pan coefficients incorporate soil-surface evaporation, canopy evaporation, and root-zone transpiration. In this study, potential evapotranspiration for an area with a particular land cover is estimated by multiplying pan evaporation for the area by the appropriate pan coefficient.

\section{Pan Evaporation}

The study area was divided into pan-evaporation zones (pan zones) on the basis of the data source and the monthly variation in pan evaporation (fig. 8). For pan zones 1, 4, and 5, the data of Ekern and Chang (1985) were used; for pan zones 2 and 3, data from the climate stations installed as part of this study were used; for pan zone 6, the data of Minyard and others (1994) were used; and for the other pan zones (those with three-digit numbers), data from HC\&S were used.

For pan zones 1, 4, and 5, mean annual pan evaporation was calculated from the map by Ekern and Chang (1985). The same methods described previously for converting lines of equal rainfall to an areal distribution of rainfall were used to convert lines of equal pan evaporation to an areal distribution. To estimate the monthly variation in pan evaporation in these zones, ratios of monthly to annual pan evaporation were calculated. Mean monthly pan-evaporation data (Ekern and Chang, 1985) for the pan-evaporation stations within or near each zone (fig. 8) were used: for pan zone 1, station 363.1; for pan zone 4, station 385; and for pan zone 5, station 415. In the water-budget calculation, pan evaporation for a given month was calculated as the annual pan evaporation multiplied by the appropriate ratio of monthly to annual pan evaporation (fig. 9; table 7).

The annual pan-evaporation map of Ekern and Chang (1985) does not cover the upland areas of West Maui Mountain, an area historically devoid of sugarcane cultivation. Pan zone 2 represents the leeward side of the mountain, and pan zone 3 the windward side. Monthly and annual pan evaporation in pan zones 2 and 3 were estimated from climate data collected for approximately 1 year at three of the climate stations installed as part of this study (see app. A). Potential evapotranspiration estimates, based on the climate data, were converted to pan evaporation by applying a pan coefficient related to the predominant vegetation at each station (see next section). Potential evapotranspiration was converted to pan evaporation so that a consistent computational approach could be used throughout the study area. The annual pan evaporation for pan zone 2 was estimated as the average annual converted pan evaporation at stations 205604156365801 and 205327156351101, the Kaulalewelewe and Pu'u Kukui climate stations, respectively. The annual pan evaporation for pan zone 3 was estimated as the average annual converted pan evaporation at stations 205712156332401 and 205327156351101, the Kahakuloa and Pu'u Kukui climate stations, respectively. Monthly variation in pan evaporation was estimated by calculating ratios of monthly to annual pan evaporation at the Kaulalewelewe station (for pan zone 2) and at the Kahakuloa station (for pan zone 3). In the water-budget calculation, pan evaporation for a given month was calculated as the annual pan evaporation multiplied by the appropriate ratio of monthly to annual pan evaporation.

The annual pan-evaporation map of Ekern and Chang (1985) also does not cover the upper west slope of Haleakalā, represented by pan zone 6. Pan evaporation was estimated by using atmometer-evaporation data collected from a five-station transect located in this zone (Minyard and others, 1994). (An atmometer is a porous-surface evaporimeter.) Data for this study were collected from June 1988 to April 1992. Atmometer measurements were calibrated to the class A pan, the standard pan used for measuring pan-evaporation in Hawai ' $\mathrm{i}$ (Giambelluca and Nullet, 1992a). The spatial pattern of evaporation on Haleakalā is primarily a function of elevation relative to the position of the trade-wind inversion (Giambelluca and Nullet, 1992b). Inspection of the data indicated two distinct trends in mean annual atmometer evaporation with respect to elevation: below 6,560 $\mathrm{ft}$ (the typical base of the trade-wind inversion), mean annual atmometer evaporation decreased with elevation gain; and above $6,560 \mathrm{ft}$, mean annual atmometer evaporation increased with elevation gain.

To estimate the spatial distribution of annual pan evaporation in zone 6, separate regressions of mean annual pan (atmometer) evaporation versus elevation were calculated for stations located above and below the trade-wind inversion. An additional data point was created for the elevation at which the transect would cross the 70-in. contour on Ekern and Chang's (1985) map if the transect were extended. This elevation was estimated at 1,500 ft. The derived relations of pan evaporation to elevation are:

At or below the trade-wind inversion (6,560-ft elevation),

$$
\begin{aligned}
& \text { annual pan evaporation [in inches] } \\
& \left.=343.9 \times \text { elevation }^{\text {in feet }}\right]^{-0.22},
\end{aligned}
$$

and above the trade-wind inversion $(6,560 \mathrm{ft})$,

annual pan evaporation [in inches] $=\left(1.2 \times 10^{-5}\right) \times$ elevation $[\text { in feet }]^{1.72}$. 


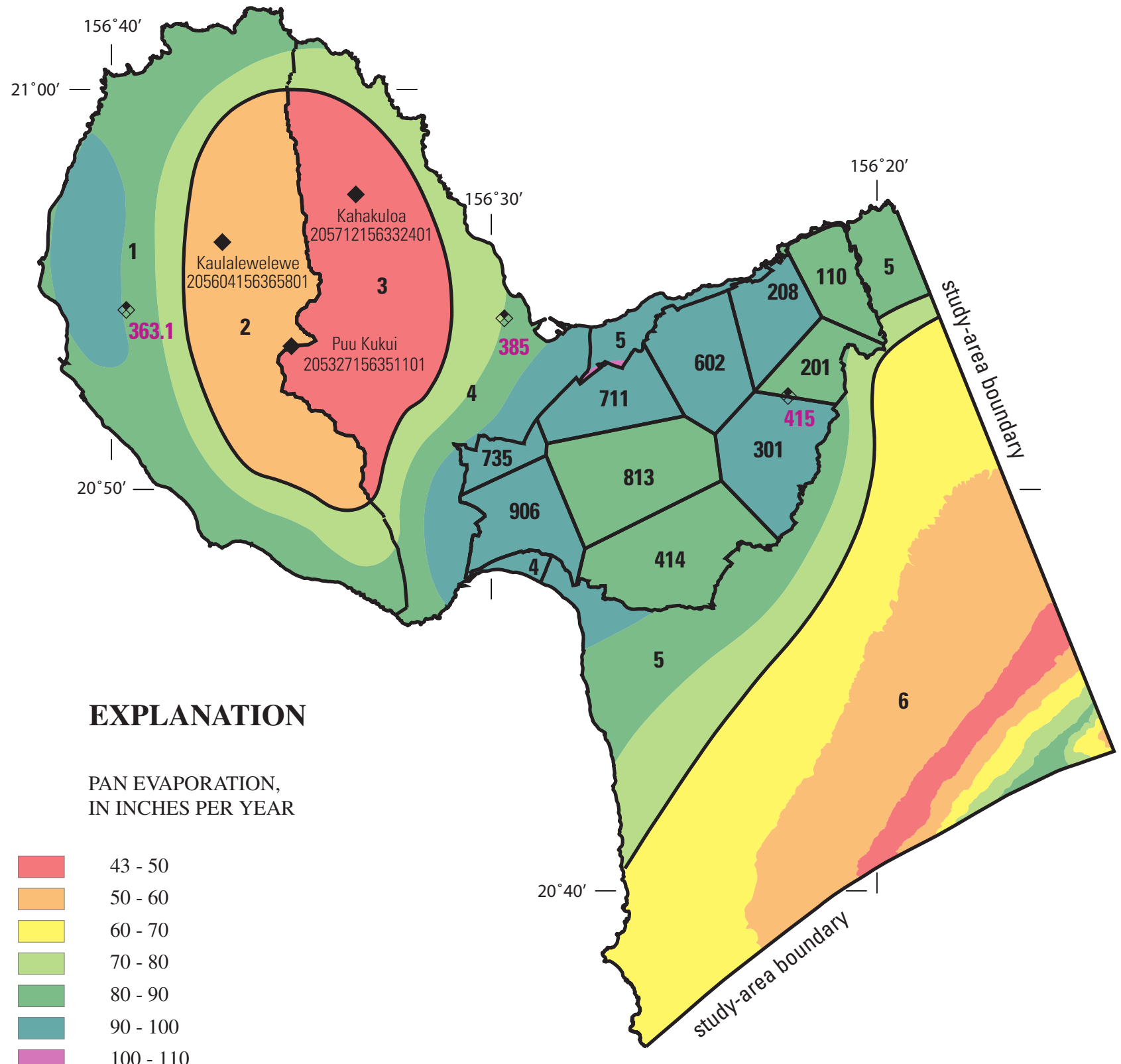

2 PAN-EVAPORATION ZONE

$\checkmark$ CLIMATE STATION WITH NAME AND USGS NUMBER

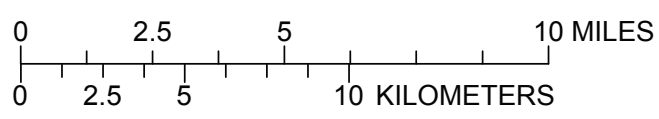

Puu Kukui

205327156351101

PAN-EVAPORATION STATION WITH NUMBER

Figure 8. Mean annual pan evaporation and pan-evaporation zones used in this study. 


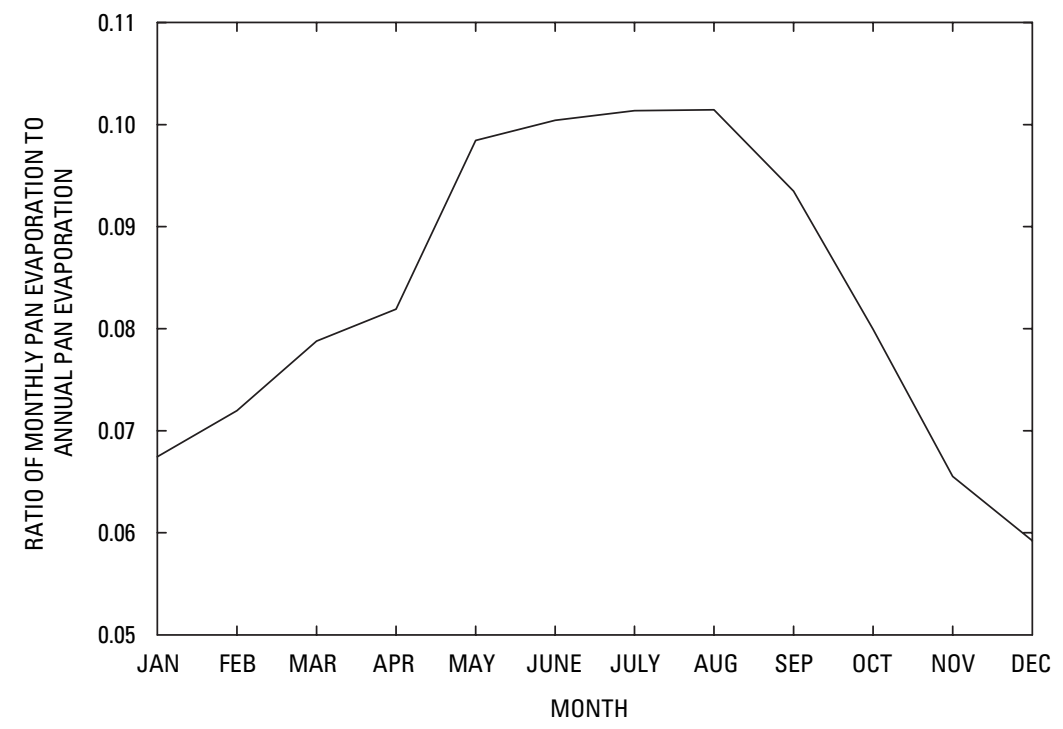

Figure 9. Mean ratio of monthly-to-annual pan evaporation for the pan-evaporation zones used in the water-budget calculation for central and west Maui, Hawai'i.

Table 7. Ratios of monthly-to-annual pan evaporation for each pan-evaporation zone used in the water-budget calculation for central and west Maui, Hawai'i.

[See figure 8 for locations of pan-evaporation zones]

\begin{tabular}{|c|c|c|c|c|c|c|c|c|c|c|c|c|}
\hline $\begin{array}{l}\text { Pan-evaporation } \\
\text { zone }\end{array}$ & Jan & Feb & Mar & Apr & May & June & July & Aug & Sep & Oct & Nov & Dec \\
\hline 1 & 0.07 & 0.07 & 0.08 & 0.08 & 0.10 & 0.09 & 0.10 & 0.10 & 0.09 & 0.08 & 0.07 & 0.06 \\
\hline 3 & 0.09 & 0.07 & 0.09 & 0.07 & 0.11 & 0.09 & 0.09 & 0.11 & 0.08 & 0.08 & 0.06 & 0.06 \\
\hline 4 & 0.06 & 0.07 & 0.09 & 0.08 & 0.09 & 0.10 & 0.10 & 0.10 & 0.09 & 0.08 & 0.07 & 0.07 \\
\hline 6 & 0.07 & 0.09 & 0.08 & 0.09 & 0.10 & 0.10 & 0.09 & 0.09 & 0.09 & 0.07 & 0.06 & 0.06 \\
\hline 110 & 0.06 & 0.06 & 0.07 & 0.08 & 0.10 & 0.10 & 0.11 & 0.11 & 0.10 & 0.09 & 0.06 & 0.06 \\
\hline 201 & 0.06 & 0.06 & 0.07 & 0.08 & 0.09 & 0.10 & 0.11 & 0.11 & 0.11 & 0.09 & 0.07 & 0.06 \\
\hline 208 & 0.06 & 0.06 & 0.07 & 0.08 & 0.10 & 0.11 & 0.12 & 0.11 & 0.10 & 0.08 & 0.07 & 0.06 \\
\hline 711 & 0.05 & 0.06 & 0.07 & 0.08 & 0.09 & 0.10 & 0.11 & 0.11 & 0.10 & 0.09 & 0.07 & 0.06 \\
\hline 735 & 0.05 & 0.05 & 0.07 & 0.08 & 0.09 & 0.11 & 0.11 & 0.11 & 0.11 & 0.09 & 0.08 & 0.05 \\
\hline 813 & 0.05 & 0.06 & 0.07 & 0.08 & 0.10 & 0.11 & 0.11 & 0.11 & 0.10 & 0.08 & 0.07 & 0.06 \\
\hline 906 & 0.05 & 0.05 & 0.07 & 0.08 & 0.09 & 0.11 & 0.11 & 0.11 & 0.11 & 0.09 & 0.08 & 0.05 \\
\hline $\begin{array}{l}\text { Area-weighted } \\
\text { mean }\end{array}$ & 0.07 & 0.07 & 0.08 & 0.08 & 0.10 & 0.10 & 0.10 & 0.10 & 0.09 & 0.08 & 0.07 & 0.06 \\
\hline
\end{tabular}


The monthly variation in pan evaporation in zone 6 was estimated by calculating ratios of monthly to annual pan (atmometer) evaporation for the station located at 3,117-ft elevation (the 950-meter station in Minyard and others, 1994). In the water-budget calculation, pan evaporation for a given month was calculated as the annual pan evaporation multiplied by the appropriate ratio of monthly to annual pan evaporation.

$\mathrm{HC} \& \mathrm{~S}$ provided a table of mean monthly pan-evaporation values for 10 of its sugarcane fields (Randall Moore and Lee Ingamells, written communs., 2005); the values were distributed across the HC\&S plantation by drawing Thiessen polygons around the centers of the 10 fields with data (panevaporation zones 110, 201, 208, 301, 414, 602, 711, 735, 813, 906, fig. 8; table 7). The area inside each Thiessen polygon was assigned the mean monthly pan evaporation of its corresponding field.

\section{Pan Coefficients}

Pan coefficients are ratios of potential evapotranspiration to pan evaporation for a given vegetative land cover. For each land-cover category, a pan coefficient was assigned on the basis of previous studies (table 8). For sugarcane fields, the pan coefficient varies throughout the crop cycle. In the waterbudget calculation, the crop cycle was divided into growth stages. Pan coefficients for sugarcane fields were assigned to each growth stage on the basis of the data of Fukunaga (1978), as shown in figure 10. Izuka and others (2005) used this approach in a water-budget study of the Lîhu'e Basin, Island of Kaua'i, Hawai' $i$. The pan coefficient for pineapple fields also varies according to the growth stage of the crop. Pine- apple consumes considerably less water than does sugarcane. Ekern (1965) reported pineapple potential evapotranspiration as 33 percent of pan evaporation for newly planted pineapple and 20 percent of pan evaporation for pineapple with a fully closed canopy. Because the pineapple crop cycle was not estimated as part of this study, a constant value of 0.25 was used for pineapple fields. Macadamia orchards were assigned a pan coefficient of 0.85 on the basis of values for similar orchard trees described by Allen and others (1998). Similar to Izuka and others (2005), all non-agricultural areas were assigned a pan coefficient of 0.85 except for wetlands (1.0), water bodies (1.0), and exposed-rock surfaces (0.2).

\section{Soil-Moisture Storage Capacity}

In the water-budget method, soil-moisture storage capacity is calculated as the product of available water capacity and root depth (see section above entitled "Water-Budget Calculations"). Available water capacity is a measure of the maximum depth of water per unit of soil available for consumption by plants and varies by soil type. Previously published soil maps and corresponding tables of available water capacities (Foote and others, 1972; Shade, 1999; Natural Resources Conservation Service, 2001) were used to distribute available water capacity in the study area. The published tables list available water capacities for each soil type as minimums and maximums at various depth ranges. In this study, a depth-weightedaverage available water capacity was calculated and assigned to each soil type (table 9).

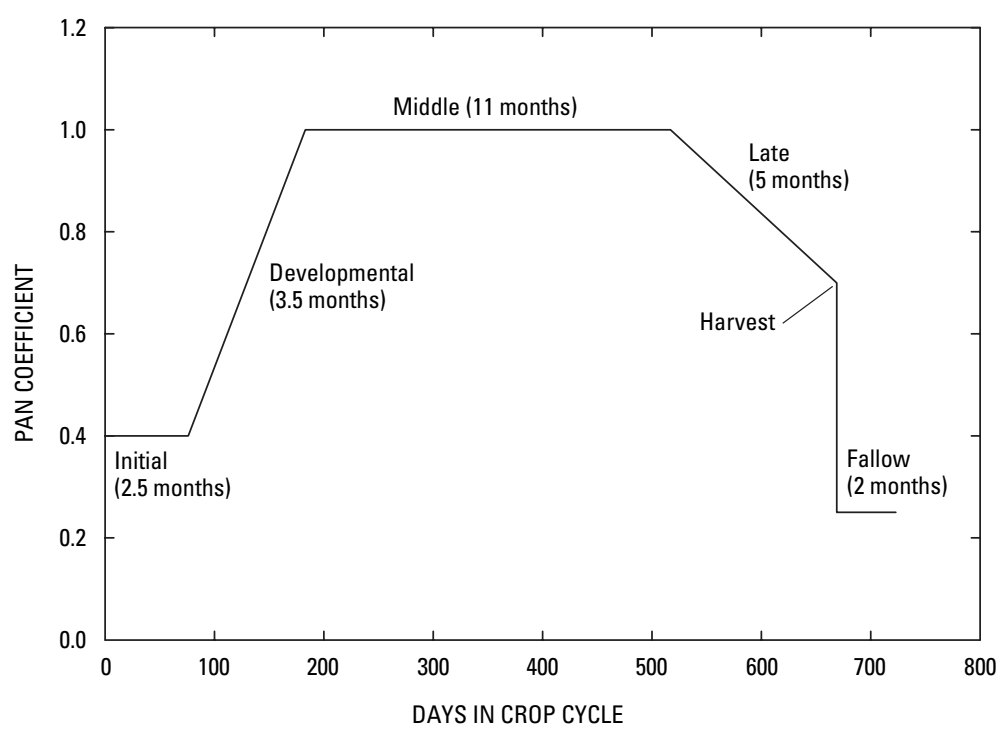

Figure 10. Pan coefficients used in the water-budget calculation for different growth stages of sugarcane (modified from Fukunaga, 1978). 
Table 8. Land-cover parameters used in the water-budget calculation for central and west Maui, Hawai'i.

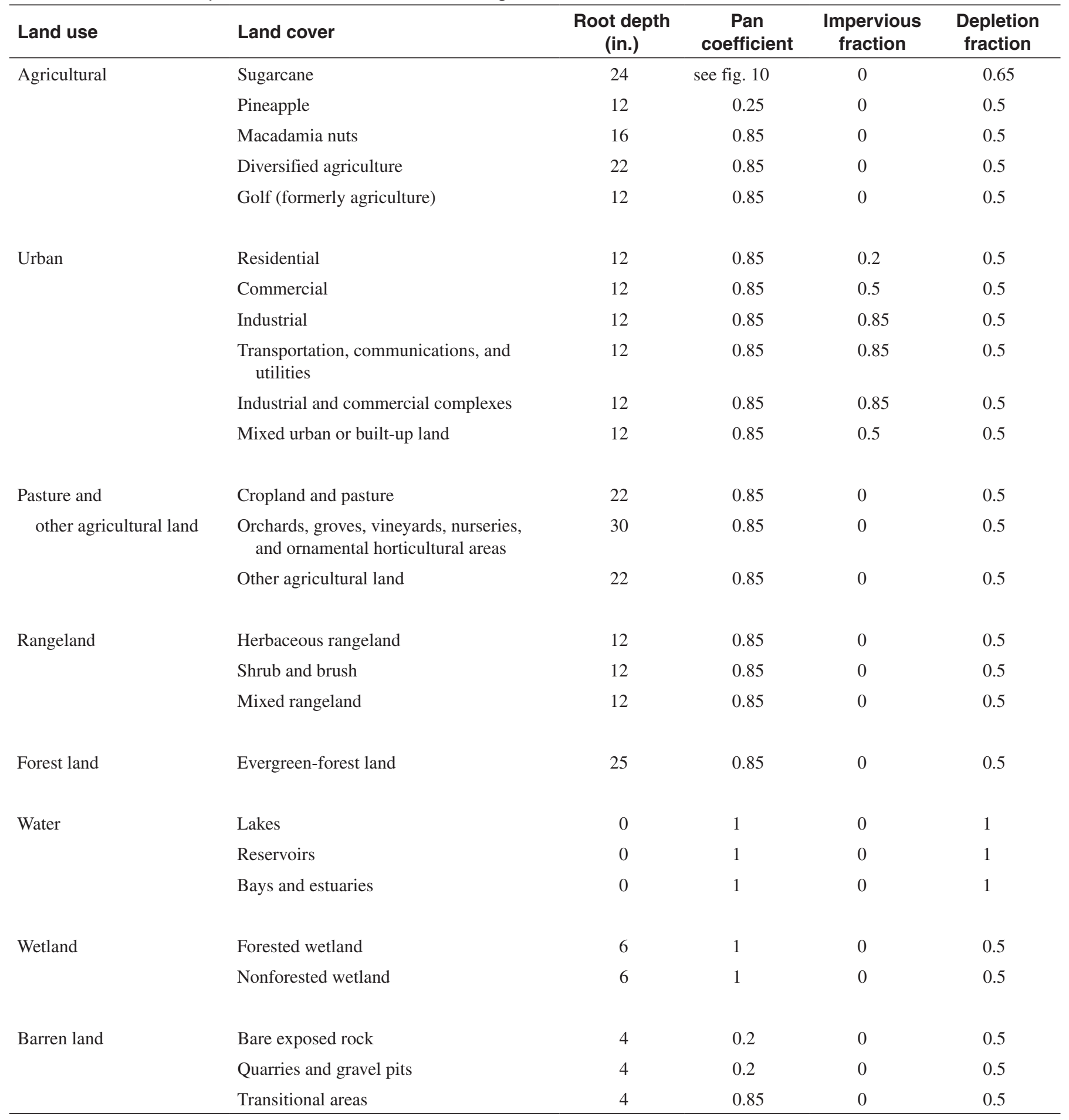


Table 9. Average available water capacities for soils in central and west Maui, Hawai'i.

[Data from Foote and others (1972), Shade (1998), and Natural Resources Conservation Service (2004). Available water capacity is average reported for uppermost soil layer]

\begin{tabular}{|c|c|c|c|}
\hline Soil series & $\begin{array}{l}\text { Available water capacity } \\
\text { (in/in. of soil) }\end{array}$ & Soil series & $\begin{array}{c}\text { Available water capacity } \\
\text { (in/in. of soil) }\end{array}$ \\
\hline 'Alae & 0.110 & Lava Flows, A'a & 0.005 \\
\hline Amalu & 0.350 & Makawao & 0.100 \\
\hline Beaches & 0.040 & Mākena & 0.180 \\
\hline Dune Land & 0.035 & Moloka'i & 0.120 \\
\hline 'Ewa & 0.110 & Nā‘iwa & 0.100 \\
\hline Fill Land & 0.150 & Oanapuka & 0.080 \\
\hline Ha‘ikū & 0.120 & ‘Ōlelo & 0.110 \\
\hline Hāna & 0.130 & Pā'ia & 0.140 \\
\hline Honolua & 0.130 & Pane & 0.150 \\
\hline Honomanū & 0.170 & Pa'uwela & 0.110 \\
\hline Honomanū-Amalu & 0.170 & Pūlehu & 0.135 \\
\hline Hydrandepts-Tropaquods & 0.250 & $\mathrm{Pu}$ 'u Pā & 0.150 \\
\hline ‘'̄ao & 0.140 & Pu'uone & 0.070 \\
\hline 'Io & 0.160 & Rock Land & 0.140 \\
\hline Jaucus & 0.045 & Rock Outcrop & 0.005 \\
\hline Kahana & 0.110 & Rough Broken Land & 0.150 \\
\hline Keāhua & 0.105 & Uma & 0.090 \\
\hline Keālia & 0.100 & Very Stony Land & 0.150 \\
\hline Keawakapu & 0.110 & Wahikuli & 0.130 \\
\hline Kō‘ele & 0.140 & Waiakoa & 0.050 \\
\hline Kula & 0.150 & Wailuku & 0.140 \\
\hline Lahaina & 0.110 & Waine'e & 0.060 \\
\hline Laumai'a & 0.150 & & \\
\hline
\end{tabular}


A root depth was assigned to each land-cover category used in the study (table 8 ), on the basis of previously published information. Sugarcane was assigned a root depth of 24 in. on the basis of a study by Lee (1927), who measured the distribution of sugarcane roots for plants grown under various conditions and determined that more than 85 percent of the roots occur in the topmost 24 in. of soil. Pineapple was assigned a root depth of 12 in., consistent with the value used by Giambelluca (1983) for pineapple grown in central O'ahu. Macadamia trees were assigned a root depth of $16 \mathrm{in}$. on the basis of a study by Firth and others (2003), who reported that, for orchard-grown macadamia trees, most fibrous roots occur in the uppermost 16 in. of soil. Rangelands (herbaceous, shrub and brush, and mixed) occur primarily on the west slope of Haleakalā and south slope of West Maui Mountain. These land-cover categories were assigned a root depth of 12 in., consistent with root depths for similar vegetation on sloped areas described by Izuka and others (2005) and Scott (1975). The land-cover category "cropland and pastures" was assigned a root depth of 22 in., consistent with that assigned to "pastures" by Oki (2002) and similar to that assigned to "grasslands" by Izuka and others (2005). Other agricultural land and diversified-agriculture areas were assigned the same root depth as cropland and pasture for lack of better data. The land-cover category "orchards, groves, vineyards, nurseries, and ornamental horticultural areas" was assigned a root depth of $30 \mathrm{in}$. on the basis of the values for several types of orchard trees used by Allen and others (1998). Developed lands were assigned a root depth of $12 \mathrm{in}$. based on Giambelluca (1983). For areas defined as evergreen forest, approximately 24 percent of the study area, a root depth of $25 \mathrm{in}$. was used based on the area-weighted average of root depths assigned to soil types in evergreen forest areas by Shade (1999). Shade (1999) selected root depths as the average depths where the soil-profile descriptions by Foote and others (1972) change from "abundant roots" or "common roots" to "few roots" or "no roots." Wetlands were assigned a root depth of 6 in. on the basis of the usage of Izuka and others (2005). Barren lands were assigned root depths of $4 \mathrm{in}$. on the basis of the root depth assigned to the soil type "rock land" by Shade (1999).

\section{Other Input}

In addition to the water-budget inputs already discussed, several other inputs are required, including initial soil-moisture storage, root depth of fallow sugarcane fields, rainfall-interception capacity for impervious surfaces, and rates of groundwater recharge from surface-water bodies and reservoirs, as summarized in table 10. The effect of initial soil-moisture storage on ground-water-recharge calculations is minor, as discussed in the subsection below entitled "Sensitivity Analysis." The values chosen for root depth of fallow sugarcane fields, rainfall-interception capacity for impervious surfaces, and rates of ground-water recharge from surface-water bodies are consistent with those selected by Izuka and others (2005) for a similar study on the Island of Kaua' $i$, Hawai' $i$. The effects of these parameters on overall study-area recharge are generally minor because they either pertain to only a small area in central and west Maui or they are applicable during only a small fraction of the time.

The rate of ground-water recharge from reservoirs was estimated from water-use data for 1998-2004 supplied by the Wailuku Water Co. (Clayton Suzuki, written commun., 2005). The annual average of water "system losses" was divided by the plan area of each reservoir in the system, assuming that 50 percent of system losses is attributable to reservoir seepage. The resulting rate, $528 \mathrm{in} / \mathrm{yr}$, was applied to every ditch-system reservoir in the study area and assumed to be equal to the ground-water-recharge rate for reservoirs (table 10). The volumetric rate of reservoir seepage in the study area was estimated at $22 \mathrm{Mgal} / \mathrm{d}$. In the water-budget calculation, a constant rate of reservoir seepage was used. In reality, the rate of reservoir seepage is time dependent; recently constructed reservoirs generally have higher rates of seepage than older ones. As a reservoir ages, silt suspended in influent water settles to the bottom of the reservoir and fills in void spaces, possibly making the bottom less permeable.

A seepage test performed on O'ahu by the Oahu Sugar Co. (unpub. data, 1958) indicates that the estimated reservoirseepage rate of $528 \mathrm{in} / \mathrm{yr}$ may be a conservative estimate. The Oahu Sugar Co. calculated the average rate of seepage from 33 reservoirs as 2,314 in/yr. This estimate may be substantially higher because their study was performed on much younger reservoirs that were not as silted as the Wailuku Water Co. reservoirs.

Table 10. Values of miscellaneous parameters used in the water-budget calculation for central and west Maui, Hawai'i.

\begin{tabular}{lc}
\hline Parameter & Value \\
\hline $\begin{array}{l}\text { Initial soil moisture } \\
\text { "Root depth" of fallow sugarcane fields }\end{array}$ & 50 percent of capacity \\
$\begin{array}{l}\text { Rainfall interception capacity for } \\
\text { impervious surfaces }\end{array}$ & $0.25 \mathrm{in.}$ \\
$\begin{array}{l}\text { Recharge rate from surface-water } \\
\text { bodies (not including reservoirs) }\end{array}$ & $12 \mathrm{in} / \mathrm{yr}$ \\
Recharge rate from reservoirs & $528 \mathrm{in} / \mathrm{yr}$ \\
\hline
\end{tabular}




\section{Recharge}

\section{Historical Recharge Estimates}

\section{6-79}

During the period 1926-79, about 51,000 acres in central and west Maui was used for sugarcane cultivation (fig. 2; table 1). Sugarcane was irrigated by using the low-efficiency furrow method, and pineapple was not irrigated during this period. In the water-budget calculation, the 1926-79 time series of rainfall was used.

The study area received an average water inflow of 1,357 $\mathrm{Mgal} / \mathrm{d}$, of which $897 \mathrm{Mgal} / \mathrm{d}$ (66 percent) was from rainfall, $437 \mathrm{Mgal} / \mathrm{d}$ (32 percent) from irrigation, and $23 \mathrm{Mgal} / \mathrm{d}$ (2 percent) from fog drip (table 11). Mean study-area recharge during this period was estimated at $693 \mathrm{Mgal} / \mathrm{d}$, or 51 percent of mean inflow. On a monthly basis, recharge was highest in March and lowest in October, coinciding with the highest and lowest monthly inflows (the sum of rainfall, fog drip, and irrigation; table 12).

In non-agricultural areas, the distribution of mean annual recharge closely resembles that of mean annual rainfall (figs. $5,11)$. The effect of agricultural land use on recharge is evident for the sugarcane fields, where recharge far exceeded that of adjacent, non-agricultural lands. Even pineapple fields showed higher rates of recharge than adjacent, non-agricultural lands. For sugarcane, elevated recharge is primarily a result of high irrigation rates, whereas for pineapple it primarily results from low evapotranspiration rates.

\section{0-2004}

The water budget for the period 1980-2004 was estimated by using five scenarios, each 5 years in duration: 1980-84, 1985-89, 1990-94, 1995-99, and 2000-04. Agricultural and urban land use was changing during this period (fig. 2; table 1). The part of the study area used for sugarcane cultivation decreased from about 51,000 acres in the 1980-84 scenario to about 40,000 acres in the 2000-04 scenario, a decrease of 22 percent. Sugarcane was irrigated by using the drip method, which consumes considerably less water than the furrow method. Pineapple fields were irrigated during this period, and macadamia-nut production was begun and subsequently halted. The time series of rainfall used in the waterbudget calculation corresponded to each of the five scenario periods.

For the period 1980-2004, the study area received a mean water inflow of 1,238 Mgal/d, of which $942 \mathrm{Mgal} / \mathrm{d}$ (76 percent) was from rainfall, $273 \mathrm{Mgal} / \mathrm{d}$ (22 percent) from irrigation, and $24 \mathrm{Mgal} / \mathrm{d}$ (2 percent) from fog drip. Mean studyarea recharge during this period was estimated at $501 \mathrm{Mgal} / \mathrm{d}$, or 40 percent of mean inflow.
The highest mean recharge, $646 \mathrm{Mgal} / \mathrm{d}$, occurred in the 1985-89 scenario, coinciding with the highest mean rainfall, $1,161 \mathrm{Mgal} / \mathrm{d}$, for any historical scenario in this study. The lowest mean recharge, $391 \mathrm{Mgal} / \mathrm{d}$, occurred in the 2000-04 scenario, coinciding with the lowest mean rainfall, $796 \mathrm{Mgal} /$ d, and lowest mean irrigation, $237 \mathrm{Mgal} / \mathrm{d}$, for any historical scenario in this study. On a monthly basis, recharge was highest in March and lowest in September, coinciding with the months of highest and lowest mean inflows (table 12).

The spatial distributions of mean annual recharge for the scenarios spanning the period 1980-2004 (fig. 11) indicate a less pronounced difference in recharge between adjacent sugarcane and non-sugarcane areas than in the 1926-79 scenario. In non-agricultural areas, the effect of spatial variation in rainfall on ground-water recharge is evident.

\section{Discussion of Historical Recharge}

Recharge for central and west Maui was 44 percent lower during the period 2000-04 than during the period 1926-79 (figs. 12, 13). The period 1926-79 had the highest estimated recharge, $693 \mathrm{Mgal} / \mathrm{d}$; irrigation rates during this period were at least 50 percent higher than in any other period considered. The period 2000-04 had the lowest estimated recharge, 391 $\mathrm{Mgal} / \mathrm{d}$; irrigation rates during this period were 46 percent less than during the period 1926-79, and rainfall was the lowest of any period.

The spatial distributions of recharge during the period 1926-2004 indicate several patterns: (1) changes in agricultural land use, resulting in corresponding changes in recharge distribution; (2) the reduction in sugarcane irrigation rates, resulting in a less pronounced difference between the recharge rates of adjacent sugarcane and non-sugarcane lands; (3) in non-agricultural areas, a variation in the spatial distributions of recharge according to the amount and spatial distribution of rainfall; and (4) in agricultural areas, a variation in the spatial distribution of recharge with the distribution of rainfall and irrigation.

Monthly recharge rates closely track the sum of monthly rainfall and irrigation rates (fig. 14). The highest monthly recharge occurs in March, and the lowest in October. Irrigation has a moderating effect on monthly recharge rates. Rainfall rates vary quite substantially between the wet winter months and dry summer months, whereas irrigation rates, which are largely driven by the difference between potential evapotranspiration and rainfall, display almost the exact opposite trend. Irrigation is highest in June and lowest in December, because potential evapotranspiration is strongly related to solar radiation (Ekern and Chang, 1985). In June, solar radiation is near its annual maximum, and in December it is at or very near its annual minimum (Ekern and Chang, 1985). Pan evaporation follows the same general pattern (fig. 9), as also does potential evapotranspiration, because it is directly proportional to pan evaporation. 


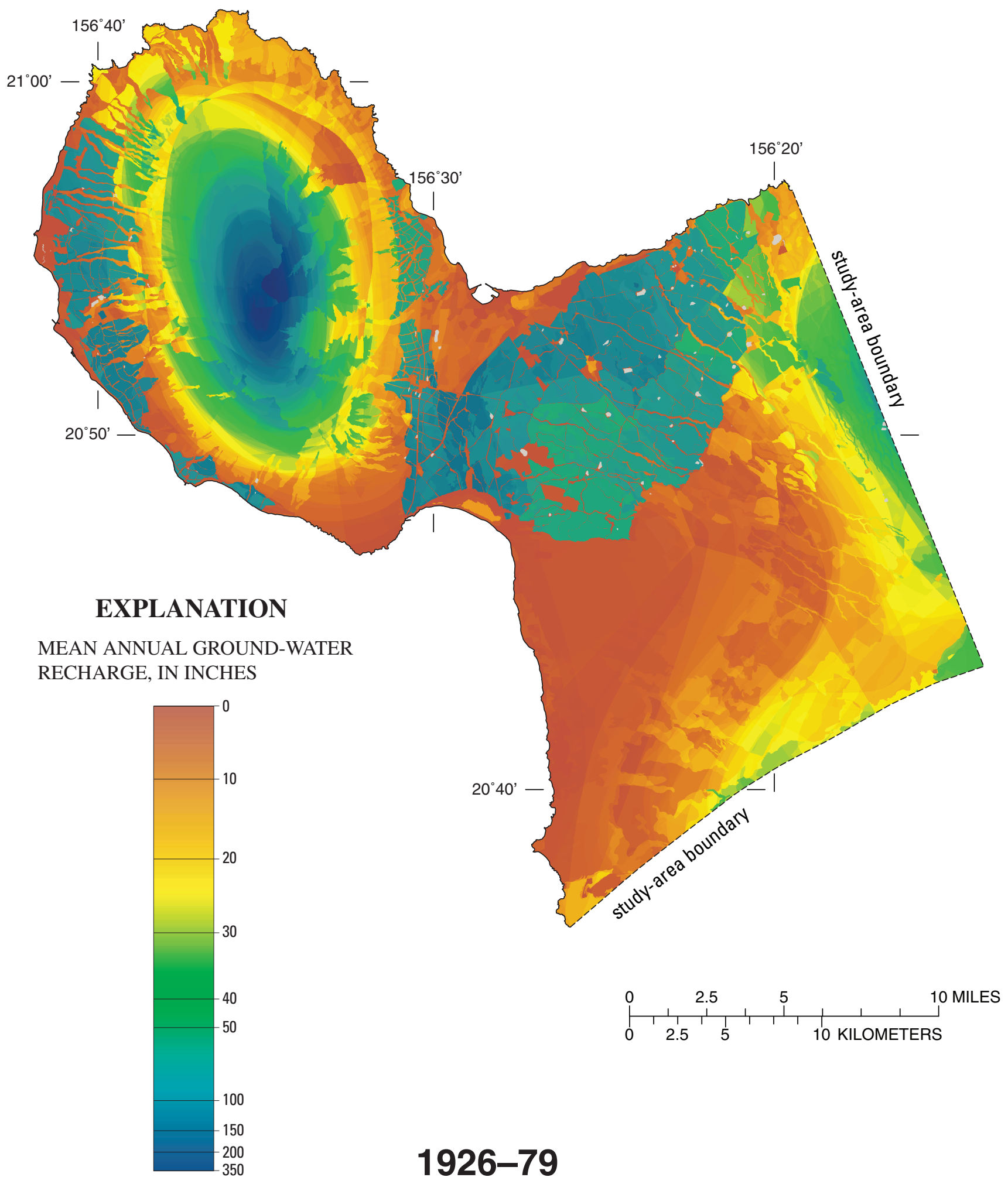

Figure 11. Distribution of estimated mean recharge for six historical scenarios, central and west Maui, Hawai'i. 


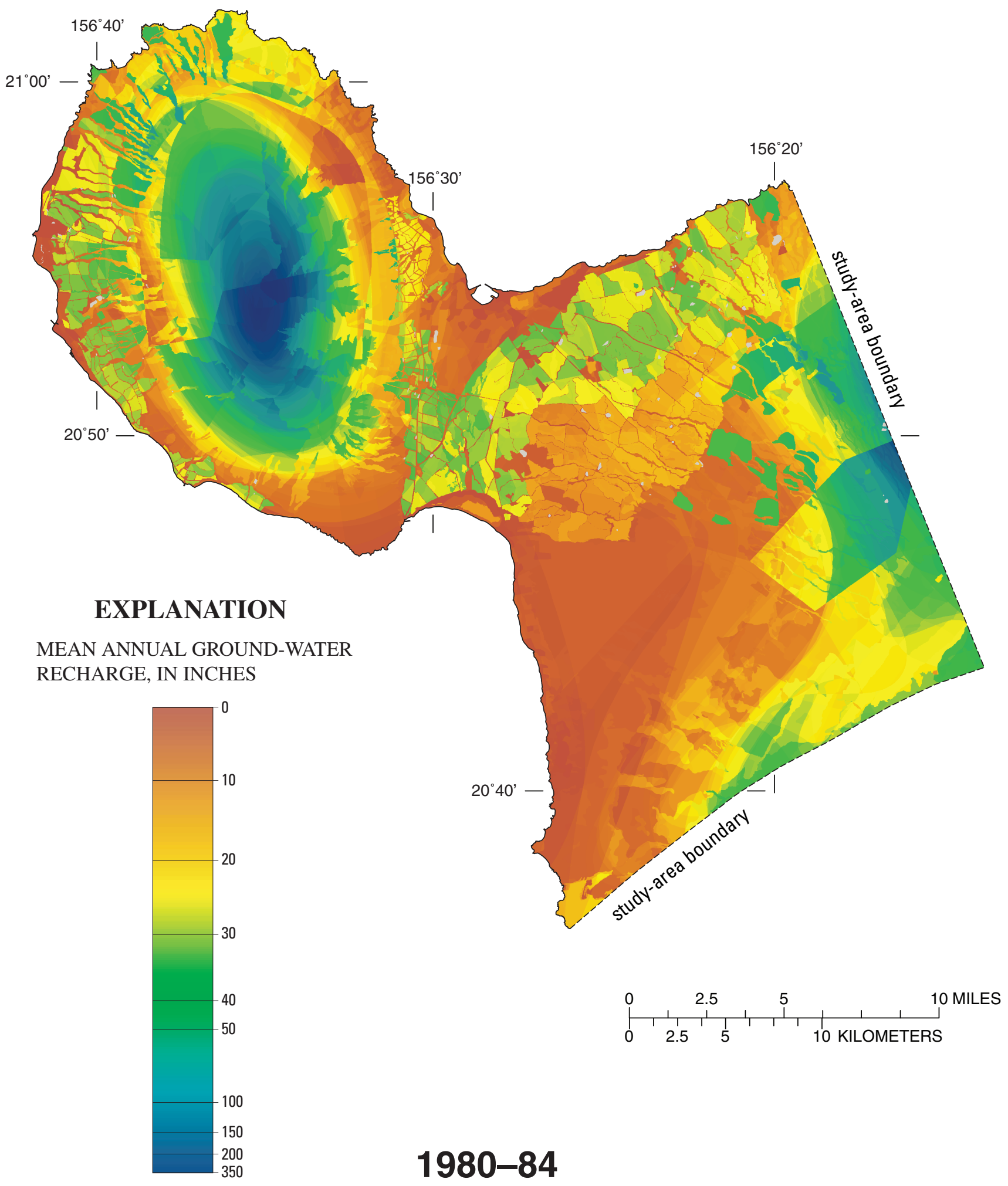

Figure 11. Continued. 


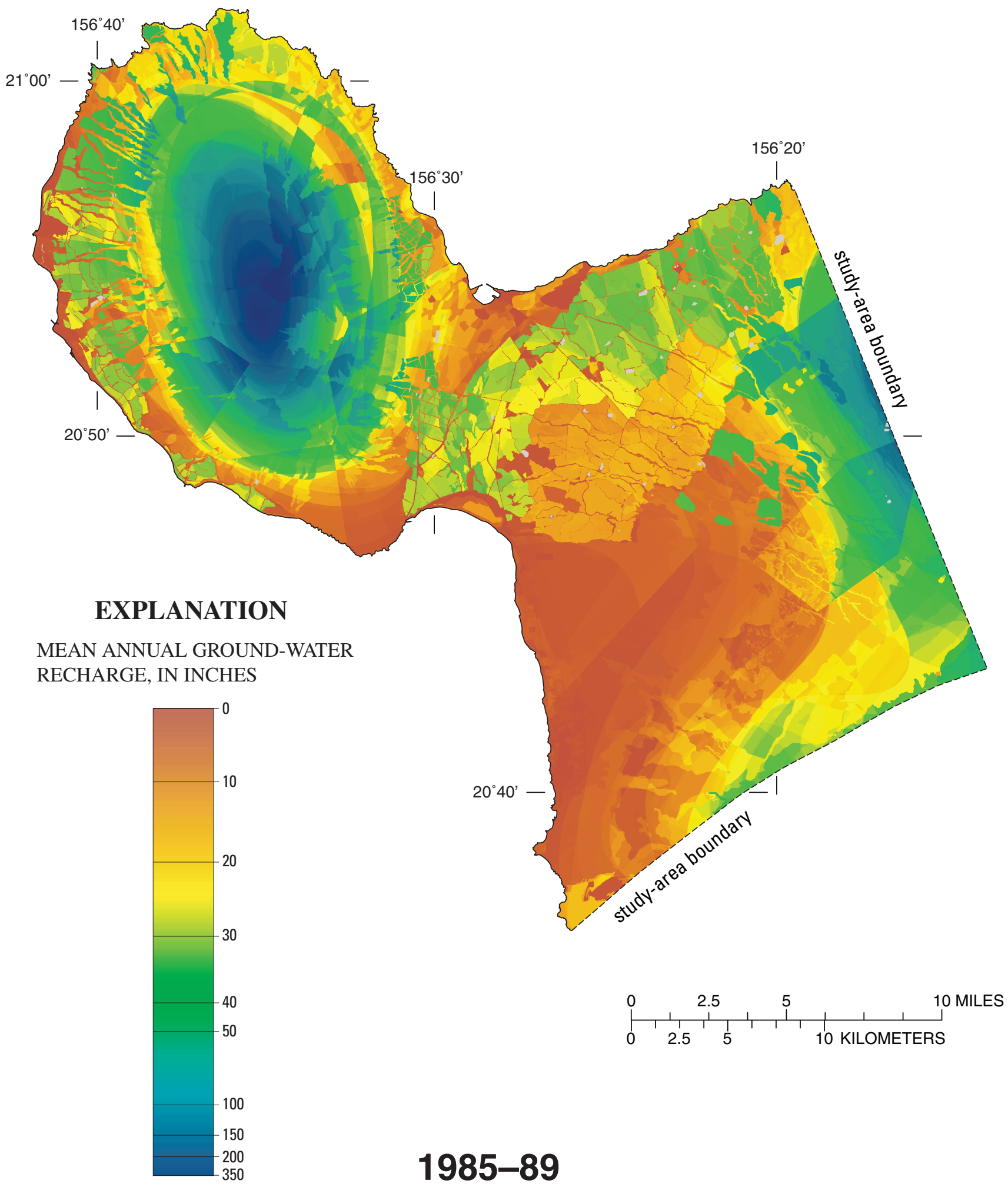

Figure 11. Continued. 


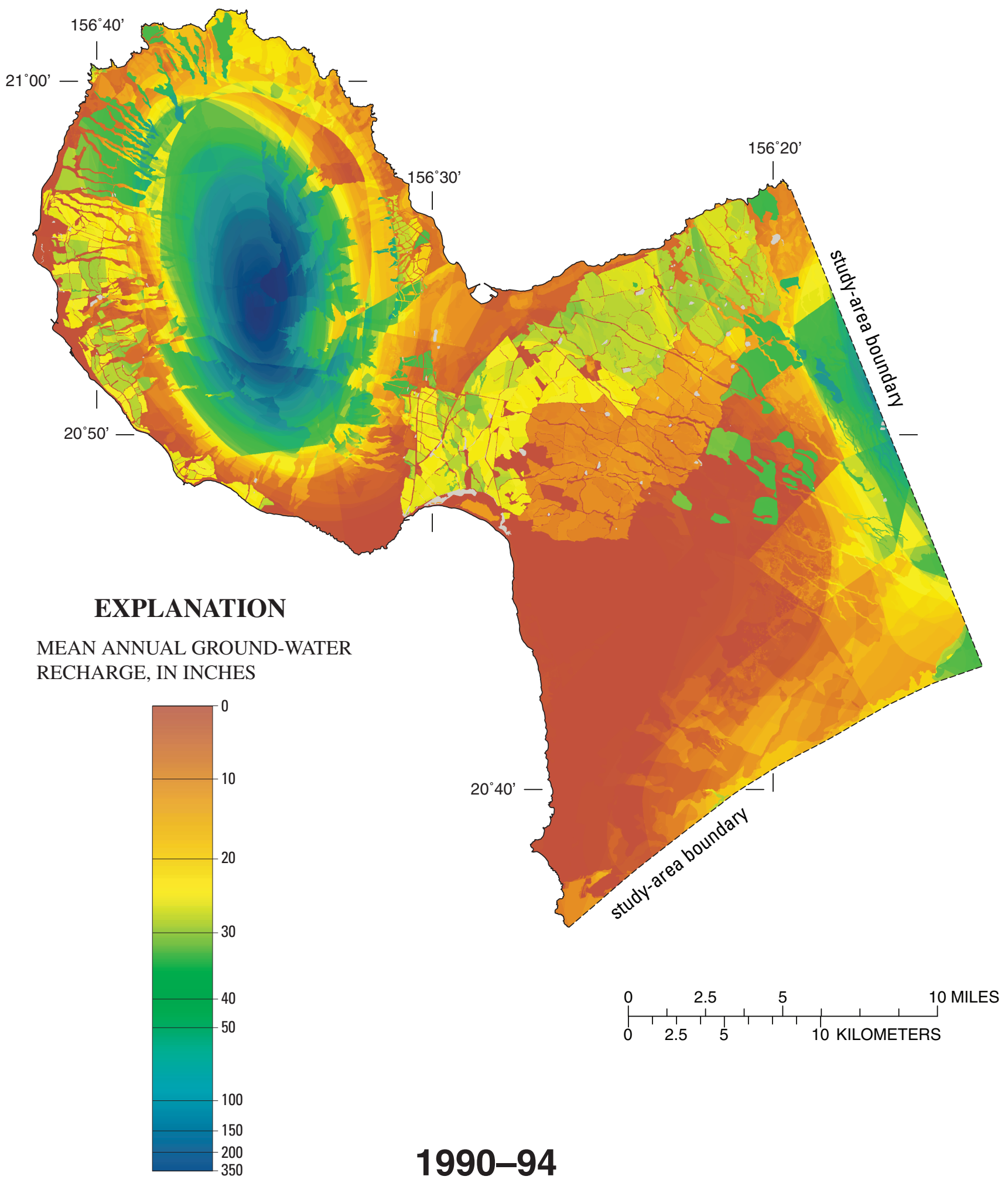

Figure 11. Continued. 


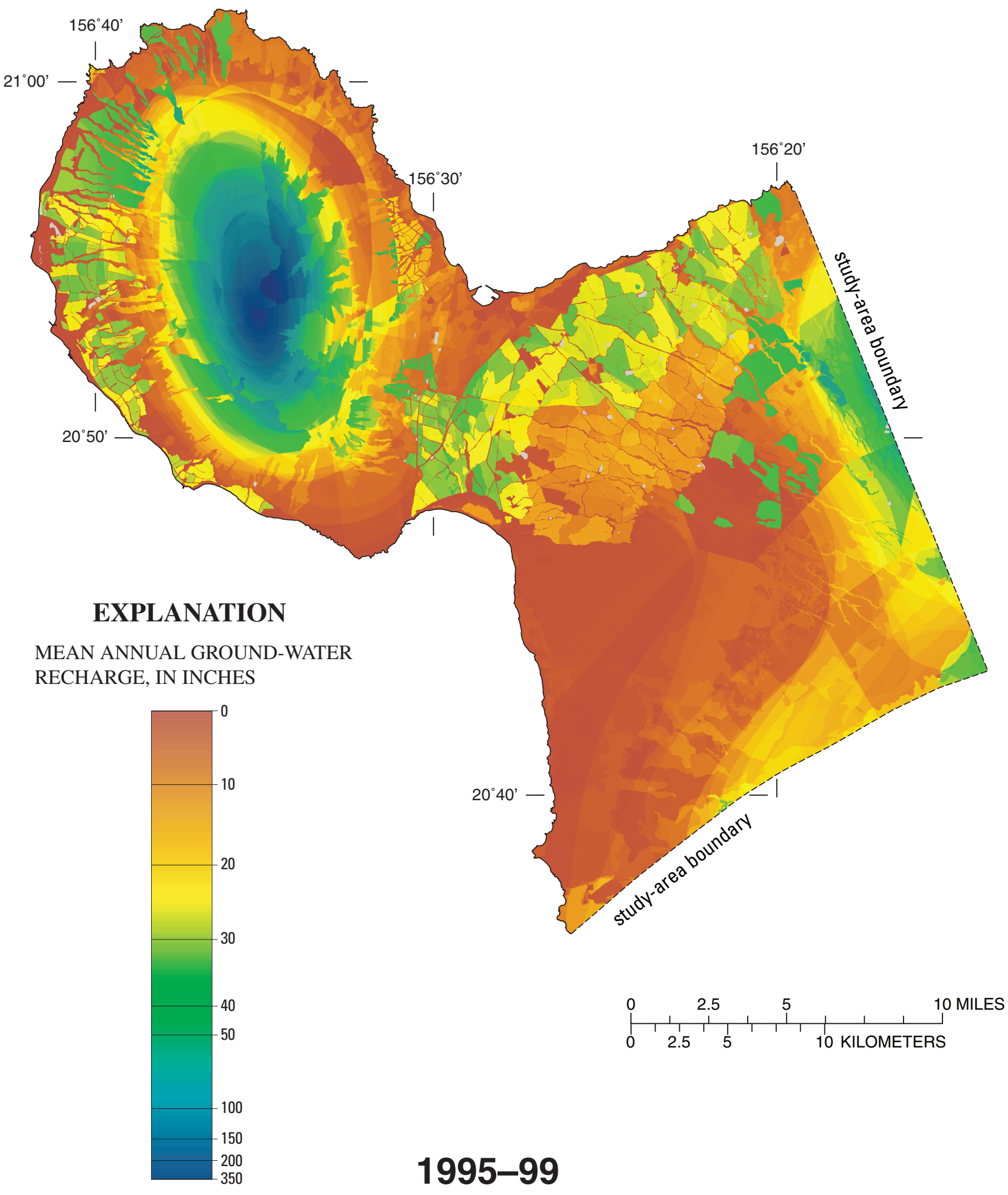

Figure 11. Continued. 


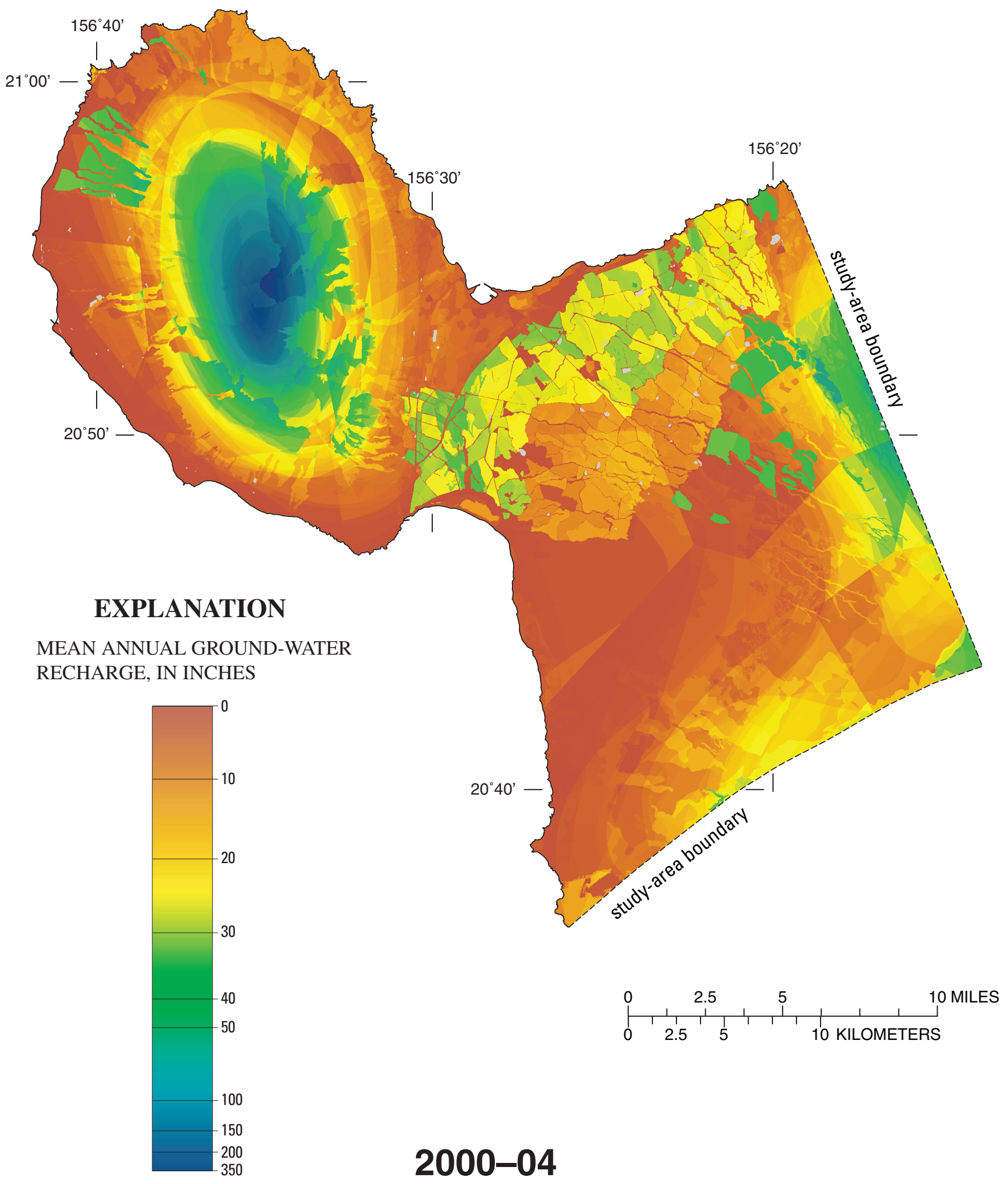

Figure 11. Continued. 
Table 11. Mean water budgets for historical and hypothetical land-use and rainfall conditions, central and west Maui, Hawai'i.

[ET, evapotranspiration]

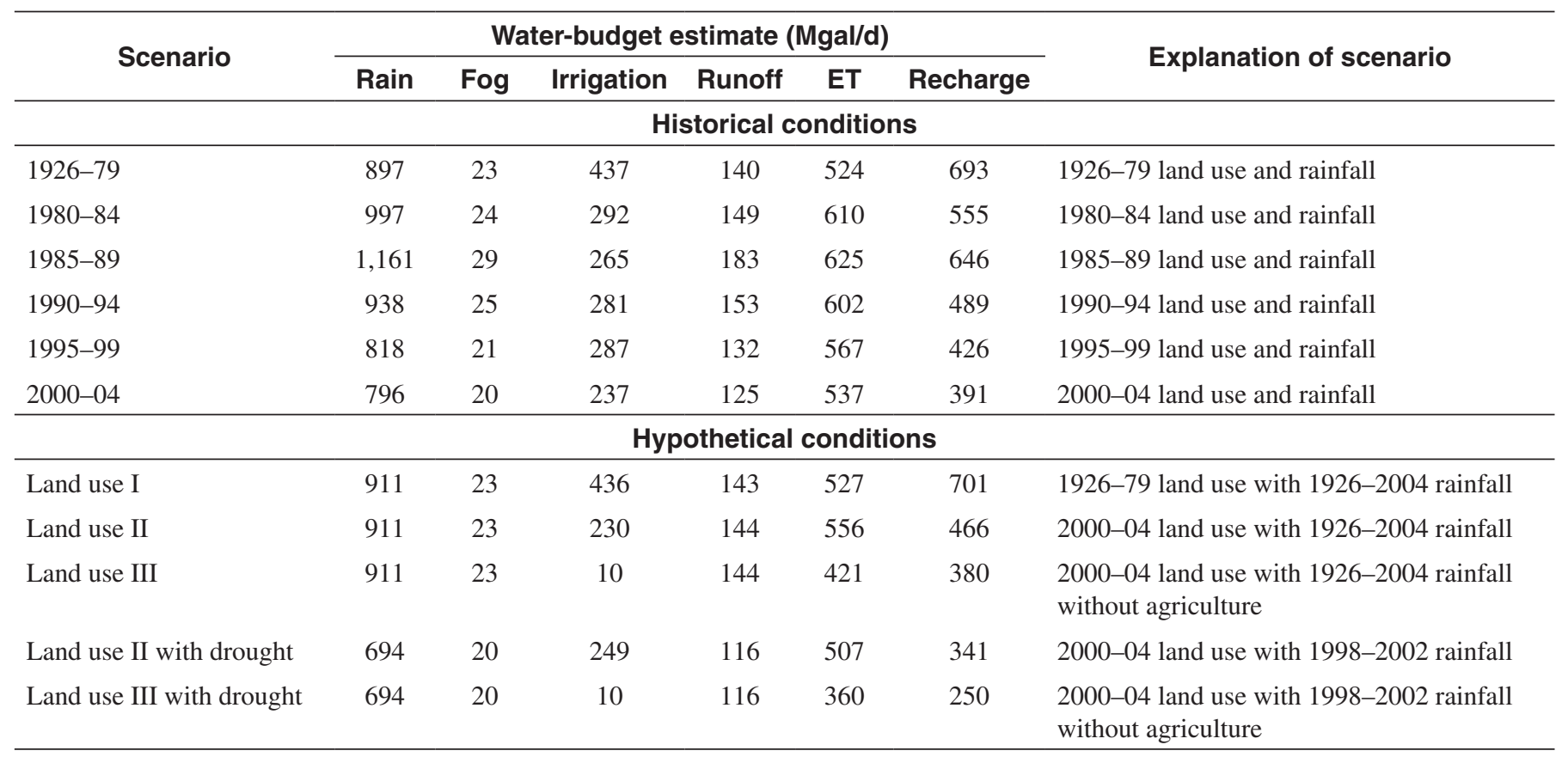

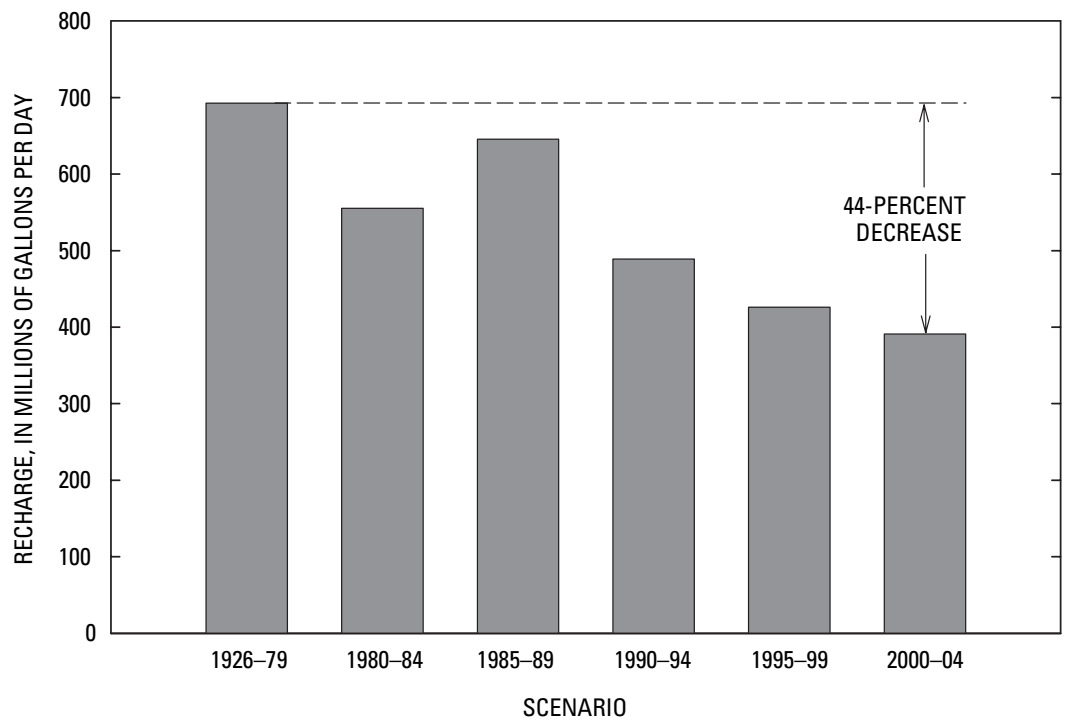

Figure 12. Estimated recharge for six historical scenarios, 1926-2004, central and west Maui, Hawai'i. 
Table 12. Mean monthly water budgets for six historical scenarios, central and west Maui, Hawai'i.

[Total inflow (rain, fog drip, irrigation) does not always equal total outflow (runoff, evapotranspiration, recharge) plus the change in soil-moisture storage due to rounding. ET, evapotranspiration; $\Delta \mathrm{SM}$, change in soil-moisture storage from previous month]

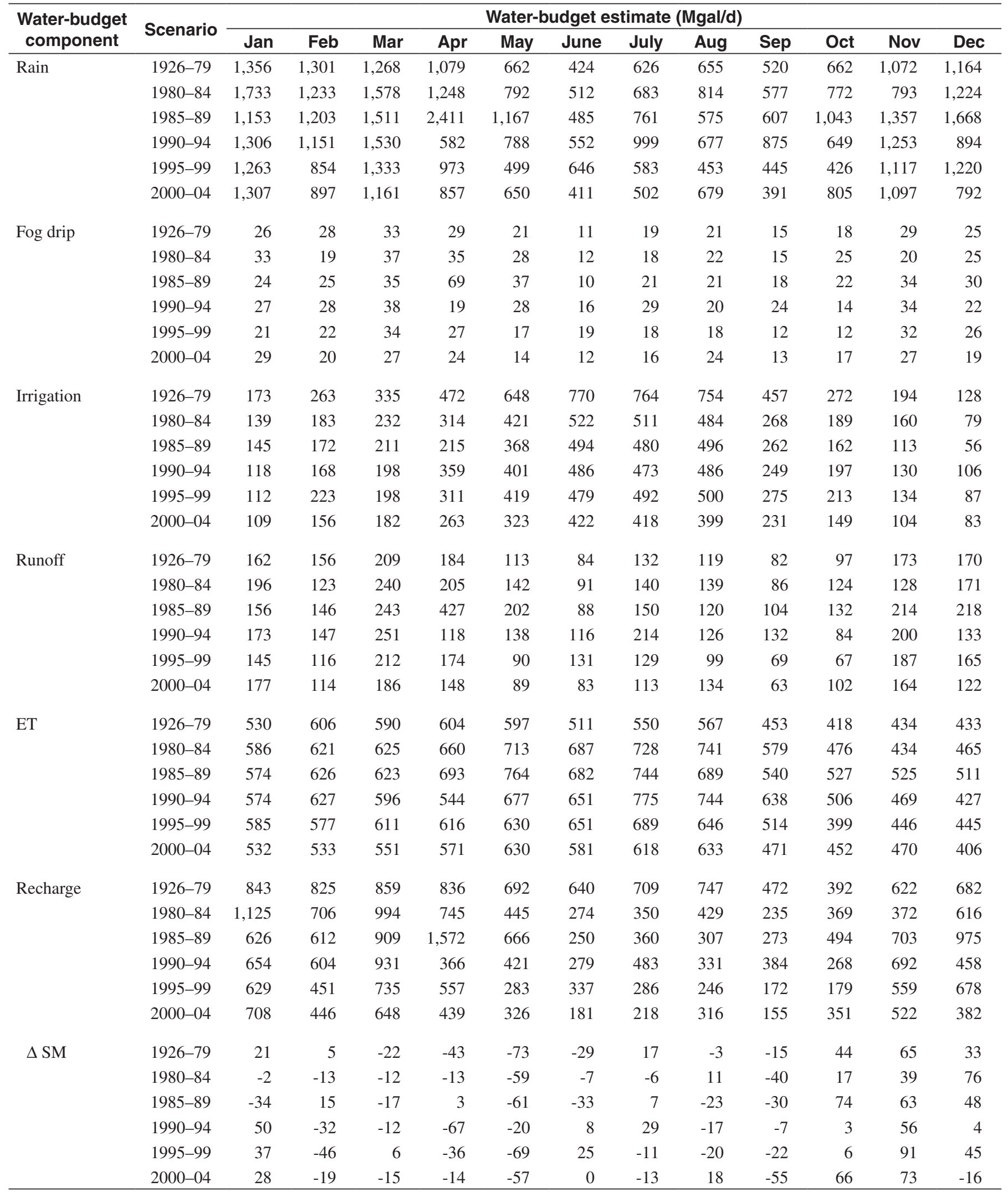




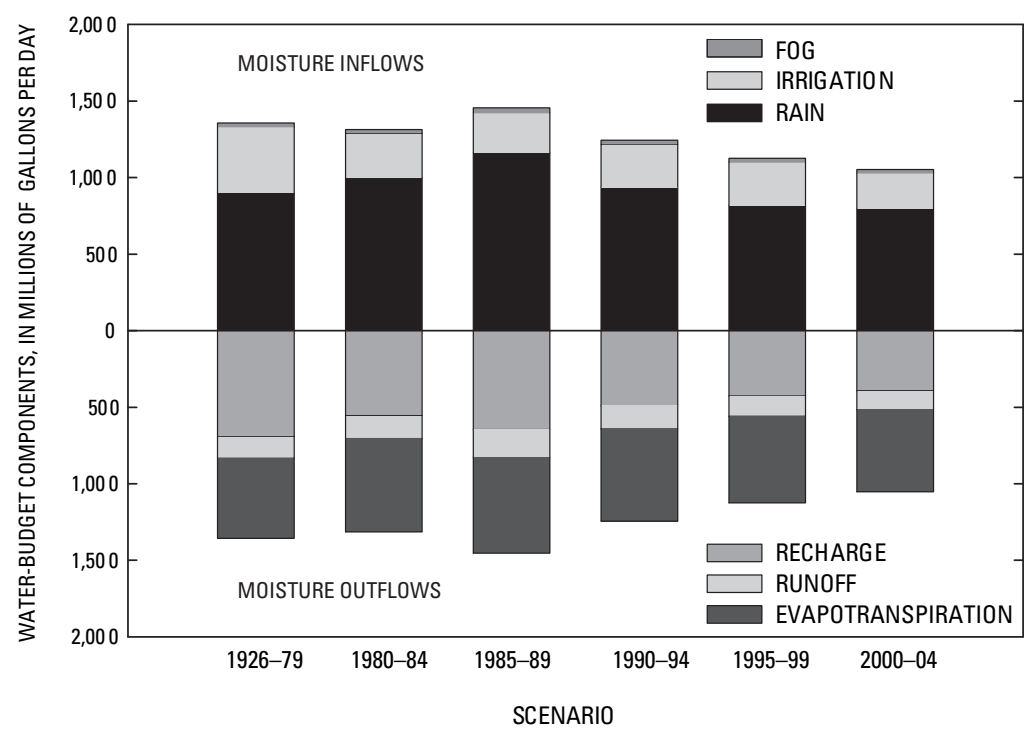

Figure 13. Estimated water-budget components for six historical scenarios, 1926-2004, central and west Maui, Hawai'i.

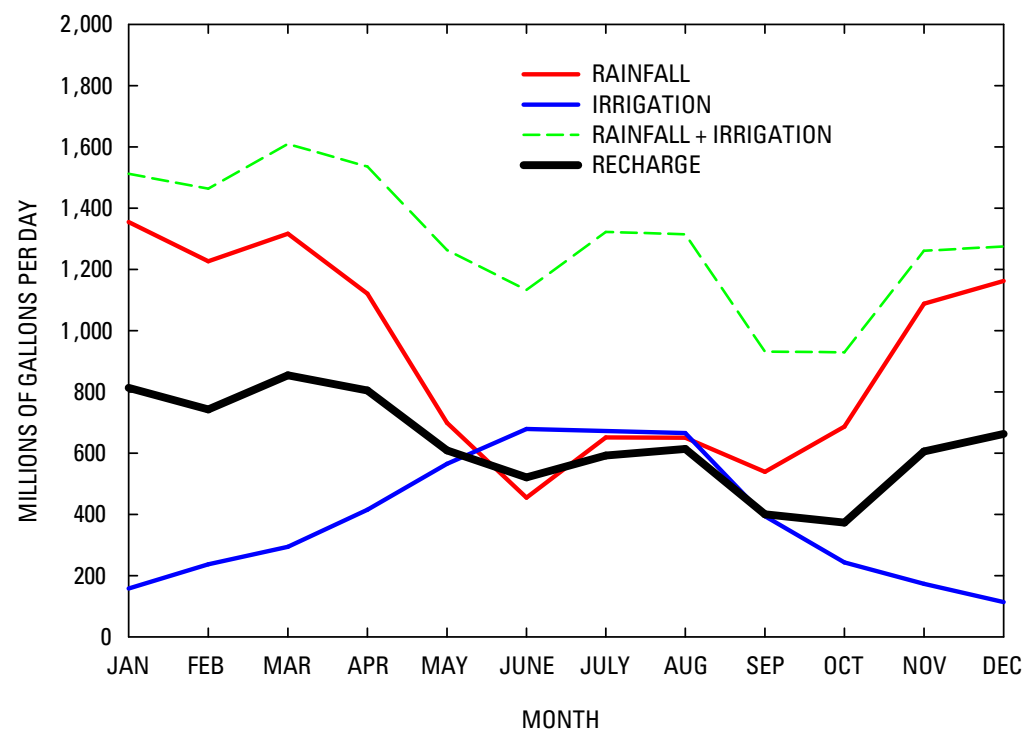

Figure 14. Estimated monthly average rainfall, irrigation, and recharge, 1926-2004, for central and west Maui, Hawai'i. 


\section{Comparison with Previous Investigation of the 'Tao Area}

Recharge to the 'Īao aquifer system (fig. 1) is particularly important to the domestic water supply on Maui. The waterbudget estimates calculated in this study were compared with those in a previous study by Shade (1997) for the 'Īao area (table 13). The area used for comparison of the two water budgets also was defined by Shade (1997). Three scenarios from each study were compared. Two of the periods do not exactly match, but they differ only slightly. Shade (1997) used a water-budget approach similar to that used in this study, with the following differences: (1) the budget was calculated by using a monthly instead of a daily time step, (2) fog drip was ignored, (3) runoff-to-rainfall ratios were calculated by using flow-duration analysis instead of hydrograph-separation analysis, (4) evapotranspiration losses were subtracted from the plant-soil system after recharge was calculated, and (5) long-term mean monthly rainfall was used instead of a historical time series.

The recharge estimates in this study are consistently higher than those calculated by Shade (1997). The inclusion of fog drip in this study and the higher runoff calculated by Shade (1997) are largely responsible for the higher estimates of recharge. In this study, fog drip contributed 10-11 Mgal/d of water inflow to the plant-soil system of the 'Īao aquifer area in addition to rainfall and irrigation. The runoff estimates in this study are lower than Shade's (1997) for each scenario considered. This difference in runoff estimates is especially significant when examined as a percentage of water inflow. To calculate runoff-to-rainfall ratios, Shade (1997) estimated base flow as the discharge corresponding to a 90-percent exceedance frequency. This choice of exceedance frequency, though common, is arbitrary. Hydrograph separation, used in this study, analyzes the unique shape of the stream hydrograph to determine base flow. Using the hydrograph-separation program of Wahl and Wahl (1995), annual base flow for 'Īao
Stream at gaging station 16604500 (fig. 7) was determined to correspond to an exceedance frequency of 71 percent. The 90percent exceedance frequency used by Shade corresponds to a flow of $19 \mathrm{ft}^{3} / \mathrm{s}$, whereas the 71-percent exceedence frequency corresponds to a flow of $26.5 \mathrm{ft}^{3} / \mathrm{s}$. Underestimation of base flow results in overestimation of direct runoff. The combination of fog-drip inclusion and lower runoff is the main reason why the recharge values calculated in this study are consistently higher than those of Shade (1997).

\section{Comparison with Water Resources Protection Plan}

In June 1990, the CWRM published its Water Resources Protection Plan (WRPP), which assigned estimates of predevelopment recharge and sustainable yield to each aquifer system in the State. The estimates of ground-water recharge for natural conditions from this study are compared with those in the WRPP (Commission on Water Resource Management, 1990) in table 14. Recharge for natural conditions was estimated by calculating the water budget, using 1926-2004 rainfall and 1926-79 land use with agricultural land covers converted to "shrub and brush" land cover (table 8). The aquifer-system boundaries as defined in the WRPP are shown in figure 15 . Aquifer systems not wholly within the study area were excluded from comparison.

The WRPP (Commission on Water Resource Management, 1990) states that "caprock areas" were excluded in the calculation of aquifer-system recharge. However, the definition and description of the areal coverage of these "caprock areas" were not clearly presented, complicating a comparison between this study and the WRPP. In Hawai 'i, "caprock" is the term commonly used to describe weathered volcanic rocks and sedimentary deposits of low permeability that overlie high-permeability volcanic rocks in coastal areas. To facilitate comparison, two methods were employed to approximate the

Table 13. Comparison of water-budget estimates by this study and Shade (1997) for the 'Tao area of Maui, Hawai'i.

['T̄ao area is defined by the Commission on Water Resource Management (1990). Total water inflow (rain, fog drip, irrigation) does not always equal total outflow (runoff, evapotranspiration, recharge) because of change in soil-moisture storage or rounding. ET, evapotranspiration]

\begin{tabular}{|c|c|c|c|c|c|c|c|c|c|c|c|}
\hline \multirow{2}{*}{ Source } & \multirow{2}{*}{ Scenario } & \multicolumn{6}{|c|}{ Water-budget estimate (Mgal/d) } & \multirow{2}{*}{$\begin{array}{c}\text { Total } \\
\text { water } \\
\text { inflow }\end{array}$} & \multicolumn{3}{|c|}{$\begin{array}{l}\text { Percentage of total water } \\
\text { inflow }\end{array}$} \\
\hline & & Rain & Fog & $\begin{array}{l}\text { Irriga- } \\
\text { tion }\end{array}$ & Runoff & ET & Recharge & & Runoff & ET & Recharge \\
\hline This study & 1926-79 & 95 & 10 & 17 & 32 & 35 & 55 & 122 & 26 & 29 & 45 \\
\hline Shade (1997) & $1926-79$ & 100 & 0 & 25 & 41 & 34 & 51 & 125 & 33 & 27 & 41 \\
\hline Shade (1997) & $1980-85$ & 100 & 0 & 9 & 41 & 29 & 40 & 109 & 38 & 27 & 37 \\
\hline This study & 1985-94 & 119 & 11 & 8 & 39 & 39 & 61 & 138 & 28 & 28 & 44 \\
\hline Shade (1997) & 1986-95 & 100 & 0 & 3 & 41 & 26 & 36 & 103 & 40 & 25 & 35 \\
\hline
\end{tabular}




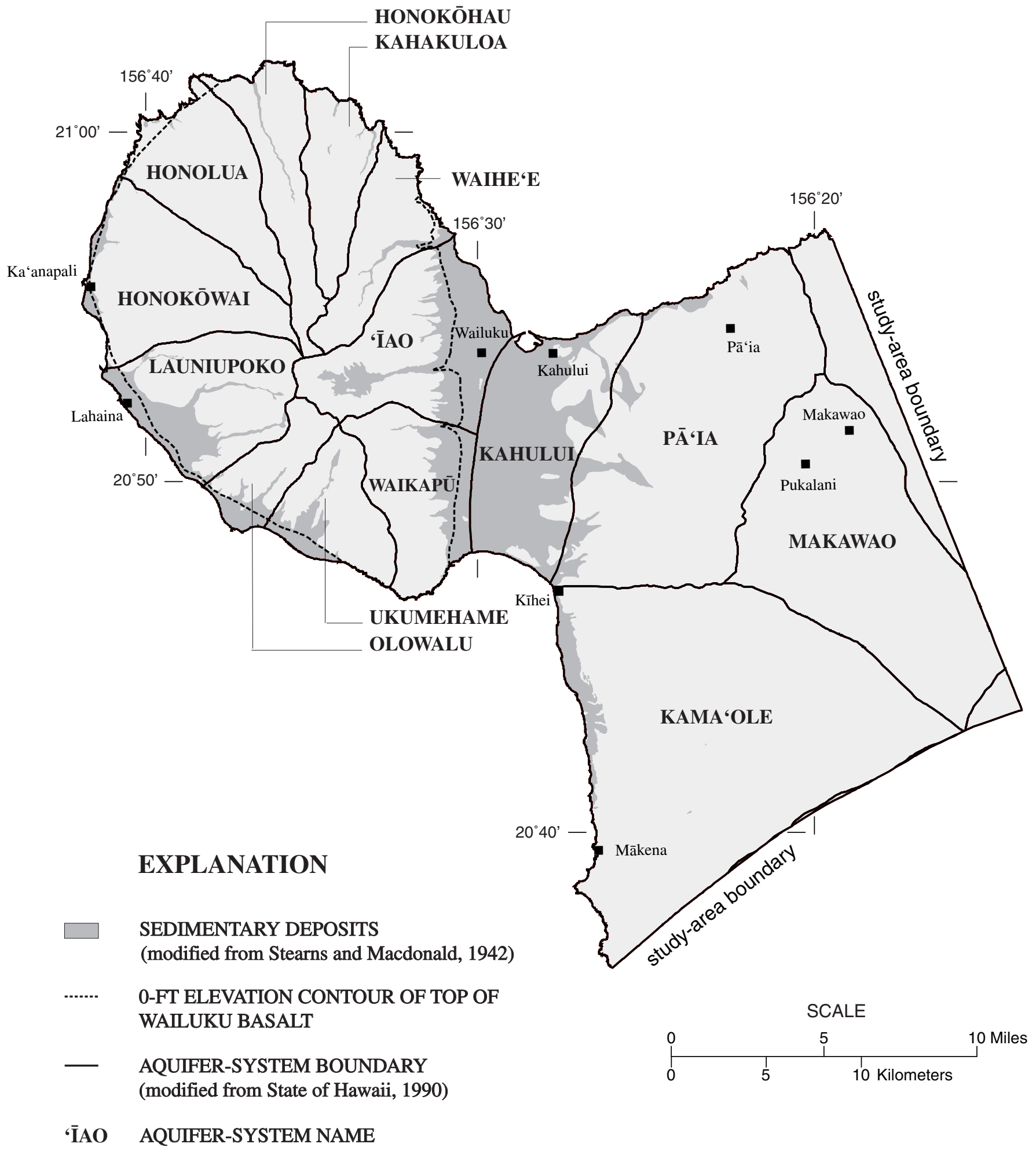

Figure 15. Locations of aquifer systems and surficial sedimentary deposits in central and west Maui, Hawai'i. 
Table 14. Comparison of water-budget estimates for natural conditions by this study with the Water Resources Protection Plan (Commission on Water Resource Management, 1990).

[See figure 15 for locations of aquifer systems. ET, evapotranspiration; WRPP, Water Resources Protection Plan (Commission on Water Resource Management, 1990). Water-budget-area descriptions: A, entire aquifer-system area, excluding caprock areas as defined in the WRPP; B, entire aquifer-system area; C, entire aquifer-system area, excluding areas seaward of the 0-ft elevation contour of the top of Wailuku Basalt; D, entire aquifer-system area, excluding all areas of sedimentary deposits as defined by Stearns and Macdonald (1942). Aquifer sector, aquifer system, and aquifer code are defined in the WRPP]

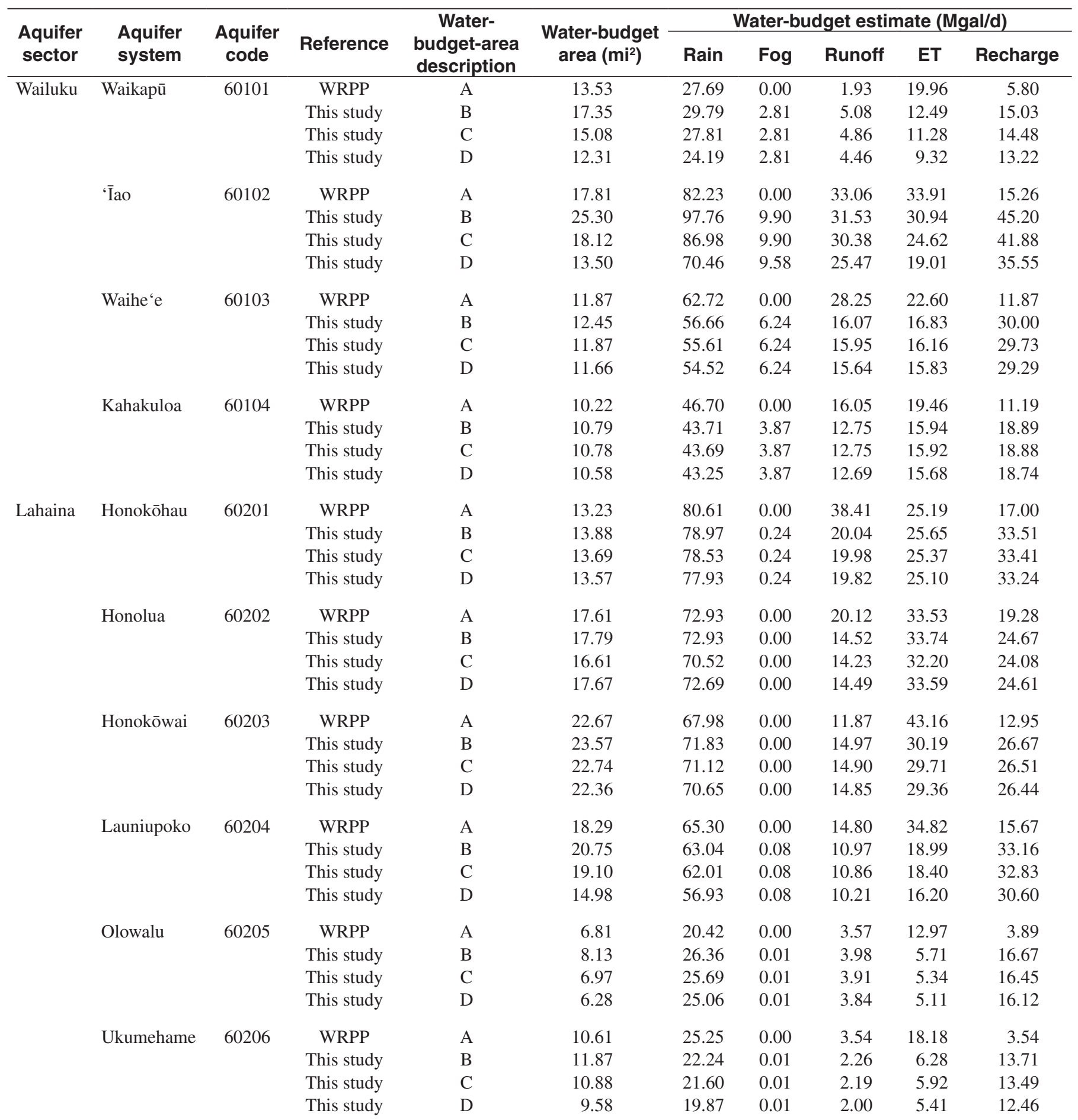


Table 14. Comparison of water-budget estimates for natural conditions by this study with the Water Resources Protection Plan (Commission on Water Resource Management, 1990)—Continued.

[See figure 15 for locations of aquifer systems. ET, evapotranspiration; WRPP, Water Resources Protection Plan (Commission on Water Resource Management, 1990). Water-budget-area descriptions: A, entire aquifer-system area, excluding caprock areas as defined in the WRPP; B, entire aquifer-system area; C, entire aquifer-system area, excluding areas seaward of the 0 - $\mathrm{ft}$ elevation contour of the top of Wailuku Basalt; D, entire aquifer-system area, excluding all areas of sedimentary deposits as defined by Stearns and Macdonald (1942). Aquifer sector, aquifer system, and aquifer code are defined in the WRPP]

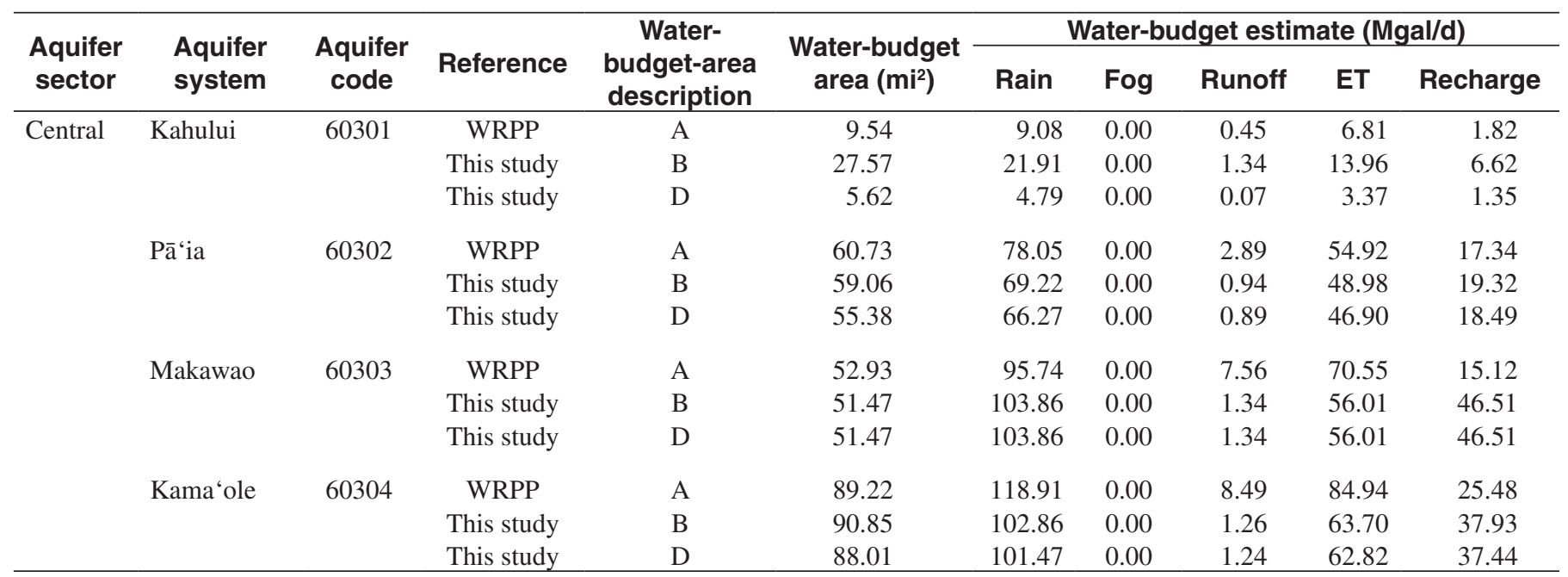

WRPP's “caprock areas." In one method (water-budget area description C, table 14), all areas seaward of the 0 -ft-elevation contour of the top of the Wailuku Basalt, the primary waterbearing unit in west Maui, were excluded from the waterbudget calculation (fig. 15). This contour was estimated from well logs and topography. In the other method (water-budget area description D, table 14), all areas designated "sedimentary deposits" on the geologic map by Stearns and Macdonald (1942) were excluded from the water-budget calculation (fig. 15). Neither method, however, produced matches (in terms of square miles) for all of the aquifer systems presented in the WRPP, although method $\mathrm{C}$ produced an exact areal match for the Waihe"e aquifer system and a near match (less than 2-percent difference) for the 'Iao aquifer system. These two aquifer systems are the most important in central and west Maui from a water-resources perspective.

In most central and west Maui aquifer systems, recharge estimates calculated by using the methods of this study are significantly higher than those presented in the WRPP (Commission on Water Resource Management, 1990) (table 14).

Areal inconsistencies aside, the reasons for differences in the recharge estimates are related to the methods used to estimate individual water-budget components. A brief, generalized description of the methods used to estimate water-budget components is provided in the WRPP. Discussion of the differences between the WRPP's methods and those used in this study is limited to generalities. The key general differences are as follows. (1) The WRPP's water budget was calculated by using an annual time step, whereas this study uses a daily time step. In general, a finer time step will generate a more realistic recharge estimate than a coarser time step. (2) The WRPP's water budget omitted an estimate of fog drip, whereas this study includes it. All other factors being equal, the inclusion of fog drip results in a higher estimate of total water inflow. (3) The WRPP's water budget estimated runoff without accounting for base flow, whereas this study accounts for base flow. Accounting for base flow will generate a lower runoff estimate. (4) The WRPP's water budget estimated annual evapotranspiration as potential (maximum) evapotranspiration, whereas this study calculates daily evapotranspiration on the basis of available soil moisture, vegetative cover, and soil type. In general, this approach will generate a lower evapotranspiration estimate than the WRPP's.

In summary, the methods used in this study generally result in a higher estimate of total water inflow than those used by the WRPP (Commission on Water Resource Management, 1990), a lower estimate of runoff than the WRPP's, and a lower estimate of evapotranspiration than the WRPP's. This combination results in the generally higher recharge estimates in this study relative to those in the WRPP.

\section{Effects of Changing Agricultural Land Use and Rainfall}

To analyze the effect of changing land use on recharge in central and west Maui, the water-budget method was used to calculate recharge for five hypothetical scenarios (table 11). To remove the effect of historical rainfall variations, the full 1926-2004 time series of rainfall was used for each scenario. The "land use I" scenario consisted of the land-cover and irrigation parameters used in the historical 1926-79 scenario; the "land use II" scenario consisted of 2000-2004 land-cover and irrigation parameters; and the "land use III" scenario consisted 


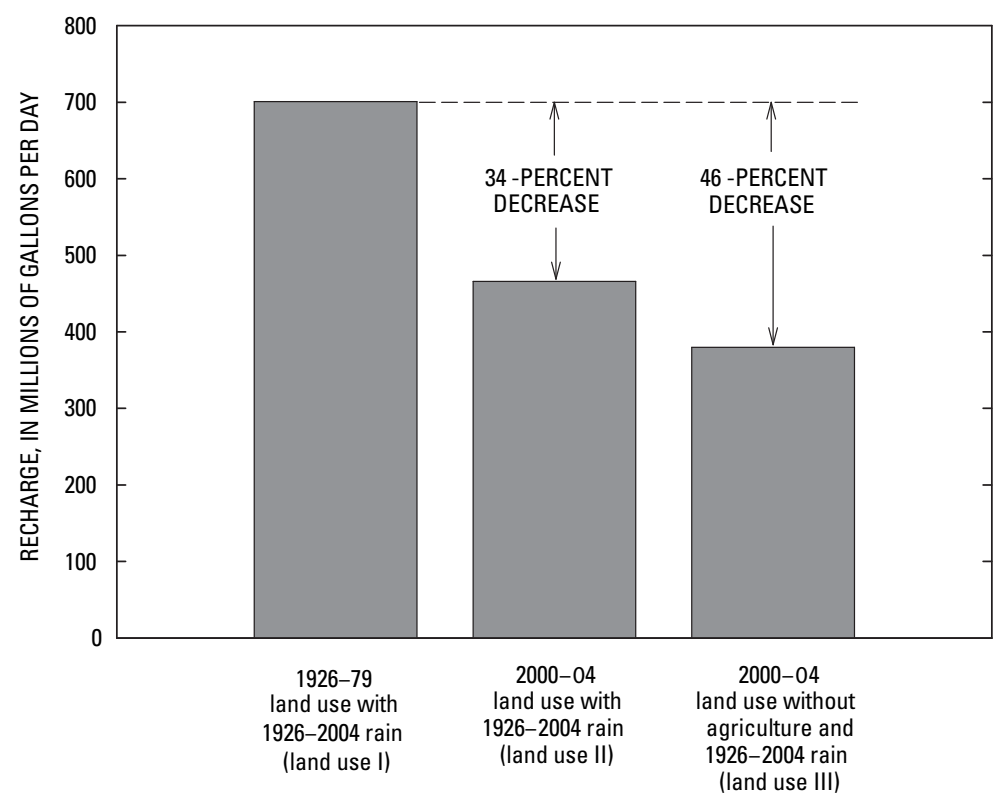

Figure 16. Effect of land-use change on estimated ground-water recharge in central and west Maui, Hawai'i.

of 2000-04 land-cover categories, except that all sugarcane and pineapple fields were changed to the "cropland and pasture" category and no irrigation was applied to these areas. The "land use III" scenario was designed to simulate recharge if a cessation of plantation-scale agriculture were to occur in central and west Maui.

Mean recharge for the entire study area in the "land use II" scenario was $466 \mathrm{Mgal} / \mathrm{d}$. This result can be considered indicative of the long-term mean recharge in the study area, given current land use and irrigation schemes. Mean recharge in the "land use II" scenario was 34 percent less than in the "land use I" scenario (fig. 16; table 11). This difference confirms that decreasing sugarcane acreage and irrigation rates were largely responsible for the 44-percent decrease in recharge estimated for historical conditions between 1926 and 2004 (fig. 14). Mean recharge in the "land use III" scenario was 18 percent less than in the "land use II" scenario (table 11). This difference, and the assumption that long-term mean climatic conditions for the period 1926-2004 represent current climatic conditions, indicates that currently, agricultural irrigation is responsible for nearly 18 percent of the mean recharge in central and west Maui.

To analyze the effect of rainfall on recharge in central and west Maui, a drought scenario (land use II with drought) was created consisting of 2000-04 land-use and irrigation parameters and the 1998-2002 rainfall time series (table 11). This period was selected by taking the lowest 5-year moving average of the annual weighting factors during the period 1926-2004 for all 33 rain gages used in the study (fig. 17). An annual weighting factor is the ratio of measured annual rainfall to mean annual rainfall. For each year between 1926 and 2004, the mean of the annual weighting factors of all gages with a complete record for that year was calculated. A 5year moving average of these means was then calculated. The time period with the lowest 5-year moving average may not correspond to the time period of lowest total rainfall because small changes in the annual weighting factors for rain gages in the high-rainfall areas of West Maui Mountain have a disproportionate effect on the total rainfall estimated for the study area. Using the mean of all 33 annual weighting factors gives a better indication of the moisture defecit in the study area, than a period of low rainfall at $\mathrm{Pu}$ 'u Kukui might indicate. The mean recharge in the "land use II with drought" scenario was 27 percent less than in the "land use II" scenario, indicating the possible effect of a previous drought on long-term mean recharge in the study area under current land-use conditions (fig. 18; table 11).

The worst-case scenario for recharge in central and west Maui (land use III with drought) was created by applying the 1998-2002 (drought) rainfall time series to the "land use III" (no agriculture) scenario. The mean recharge for the entire study area was estimated to be $250 \mathrm{Mgal} / \mathrm{d}$ or 46 percent less than in the "land use II" scenario (466 Mgal/d), the long-term mean for current land-use conditions in central and west Maui (fig. 18; table 11).

\section{Sensitivity Analysis}

Uncertainty exists in many of the water-budget inputs used in this study. The values used in the calculation described above were deemed to be most reasonable. To analyze the 


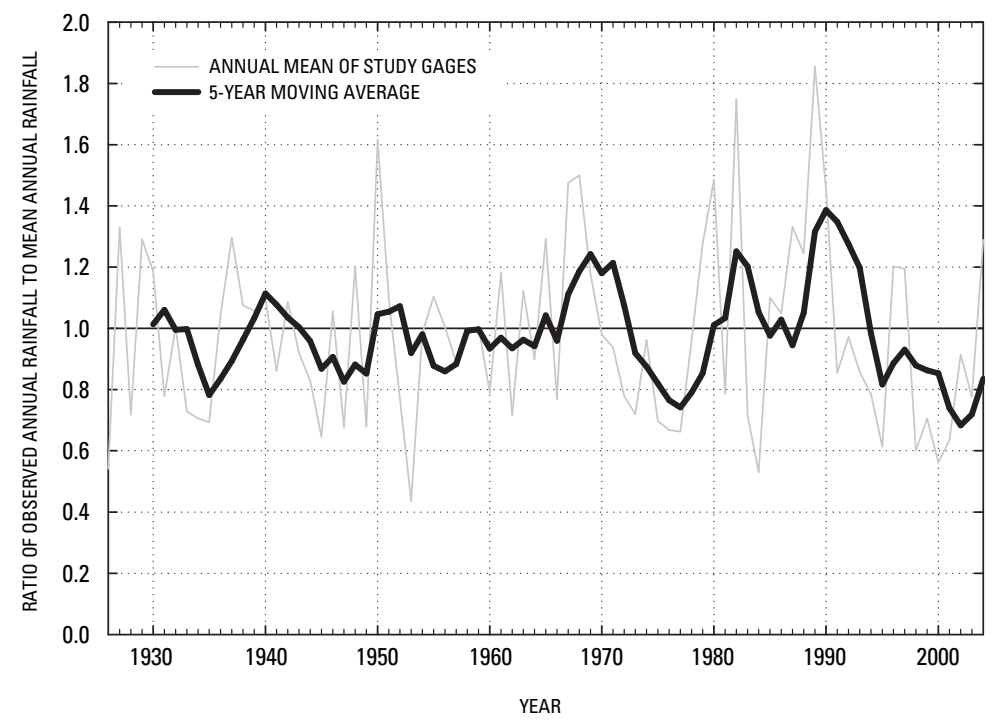

Figure 17. Five-year moving average of the mean ratio of measured annual rainfall to mean annual rainfall for the 33 rainfall gages used in the water-budget calculation for central and west Maui, Hawai'i.

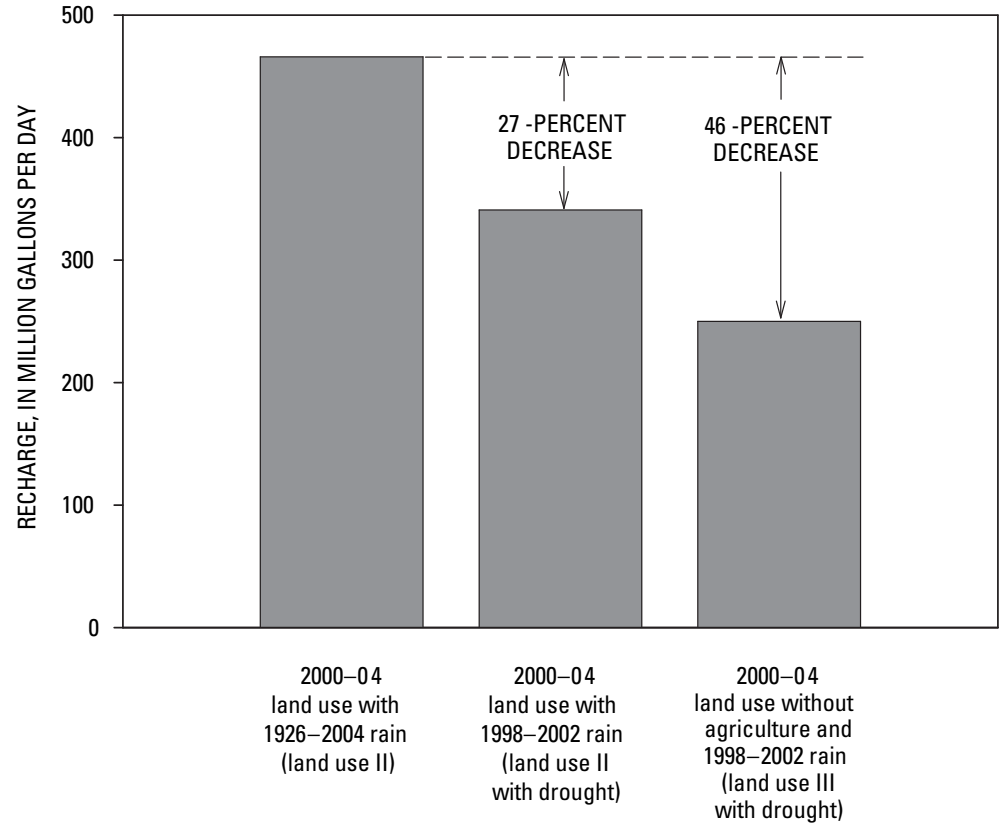

Figure 18. Effect of rainfall reduction on estimated ground-water recharge in central and west Maui, Hawai'i. 
Table 15. Results of sensitivity testing for selected water-budget inputs used in the calculation of ground-water recharge for central and west Maui, Hawai i.

[Base case is scenario 2000-04 (table 11). ET, evapotranspiration]

\begin{tabular}{|c|c|c|c|c|c|c|c|c|}
\hline \multirow{2}{*}{ Water-budget input } & \multirow{2}{*}{ Input value } & \multicolumn{6}{|c|}{ Water-budget estimate (Mgal/d) } & \multirow{2}{*}{$\begin{array}{l}\text { Percent difference in recharge } \\
\text { relative to the } 2000-04 \text { historical } \\
\text { scenario }\end{array}$} \\
\hline & & Rainfall & Fog & Irrigation & Runoff & ET & Recharge & \\
\hline \multirow[t]{2}{*}{ Initial soil moisture } & $0 \%$ of soil-moisture capacity & 796 & 20 & 237 & 125 & 535 & 390 & 0 \\
\hline & $100 \%$ of soil-moisture capacity & 796 & 20 & 237 & 125 & 539 & 393 & 1 \\
\hline \multirow[t]{2}{*}{ Root depth } & $50 \%$ of base case & 796 & 20 & 237 & 125 & 489 & 440 & 12 \\
\hline & $200 \%$ of base case & 796 & 20 & 237 & 125 & 567 & 361 & -8 \\
\hline \multirow[t]{2}{*}{ Runoff-to-rainfall ratio } & $50 \%$ of base case & 796 & 20 & 236 & 65 & 545 & 442 & 13 \\
\hline & $150 \%$ of base case & 796 & 20 & 238 & 185 & 527 & 343 & -12 \\
\hline \multirow[t]{2}{*}{ Available water capacity } & Low reported value ${ }^{1}$ & 796 & 20 & 237 & 125 & 529 & 399 & 2 \\
\hline & High reported value ${ }^{1}$ & 796 & 20 & 237 & 125 & 544 & 384 & -2 \\
\hline \multirow[t]{2}{*}{ Fog-drip-to-rainfall ratio } & $50 \%$ of base case & 796 & 10 & 237 & 125 & 537 & 382 & -2 \\
\hline & $200 \%$ of base case & 796 & 40 & 237 & 125 & 538 & 411 & 5 \\
\hline \multirow[t]{2}{*}{ Pan coefficient } & $82 \%$ of base case & 796 & 20 & 237 & 125 & 477 & 451 & 15 \\
\hline & $118 \%$ of base case ${ }^{2}$ & 796 & 20 & 237 & 125 & 591 & 339 & -13 \\
\hline \multirow[t]{2}{*}{ Irrigation } & $80 \%$ of base case & 796 & 20 & 190 & 125 & 525 & 357 & -9 \\
\hline & $120 \%$ of base case & 796 & 20 & 284 & 125 & 541 & 435 & 11 \\
\hline \multirow[t]{2}{*}{ Reservoir seepage } & $50 \%$ of base case & 796 & 20 & 237 & 125 & 548 & 380 & -3 \\
\hline & $150 \%$ of base case & 796 & 20 & 237 & 125 & 527 & 402 & 3 \\
\hline
\end{tabular}

${ }^{1}$ High and low values reported in Foote and others (1972).

${ }^{2}$ Except for evergreen-forest land areas below the fog zone receiving average annual rainfall greater than 80 inches. For these areas, the pan coefficient was increased from 0.85 to $1.3,53 \%$ of base case. 
effect of uncertainty in water-budget inputs on estimated recharge, the water-budget was rerun while changing one input value at a time within a reasonable range. For some poorly studied inputs, such as the fog-drip-to-rainfall ratio, this range was arbitrarily selected. A range of recharges for each test was calculated by holding all other inputs at their original values and varying the test input. The resulting recharge estimates were compared with the recharge estimated for the 2000-04 historical-conditions scenario (base case) (table 15). The parameters tested were (1) initial soil moisture, (2) root depth, (3) runoff-to-rainfall ratio, (4) available water capacity, (5) fog-drip-to-rainfall ratio, (6) pan coefficient, (7) irrigation, and (8) reservoir seepage.

Parameters with minor effects on recharge were initial soil moisture, available water capacity, fog-drip-to-rainfall ratio, and reservoir seepage. Varying these parameters within the ranges specified in table 15 resulted in a difference in recharge of 5 percent or less relative to the 2000-04 base case. Initial soil moisture was tested at the full range, 0 to 100 percent of soil-moisture storage capacity. Available water capacities were tested by using the low reported value and the high reported value in the report by Foote and others (1972). The fog-drip-to-rainfall ratio was doubled and halved; reservoir seepage was first increased by 50 percent and then decreased by 50 percent.

Parameters with significant effects on recharge were root depth, runoff-to-rainfall ratio, pan coefficient, and irrigation. Root depths for individual vegetation types are known to vary spatially according to soil characteristics (Giambelluca, 1983), and data are available for the root depths of various soil types (see Foote and others, 1972); however, these depths are based on a limited number of soil cores used to characterize each soil type, and so caution should be exercised in applying soil-based root depths regionally. For the sensitivity analysis, root depths were doubled and halved, consistent with the approach used by Izuka and others (2005). The resulting mean recharges were 8 percent lower and 12 percent higher, respectively, than in the 2000-04 base case.

Runoff-to-rainfall ratios were increased by 50 percent and decreased by 50 percent, consistent with the sensitivity analyses by Oki (2002) and Izuka and others (2005). The resulting recharges were 12 percent lower and 13 percent higher, respectively, than the in 2000-04 base case.

For sensitivity tests on pan coefficients, Oki (2002) and Izuka and others (2005) varied values by 18 and 20 percent, respectively. In this study, an increase of 18 percent in the sugarcane pan coefficient results in a value of 1.18 during the middle stage of growth for that crop (see fig. 10), consistent with the results of Jones (1980), who reported that sugarcane can have a pan coefficient as high as 1.2. As previously discussed, the range of pan coefficients for pineapple is 0.20 to 0.33 , depending on the age of the crop (Ekern, 1965). Decreasing the pan coefficient used for pineapple $(0.25)$ by 18 percent, results in a pan coefficient of 0.205 . Giambelluca (1983) estimated that wet forest areas on $\mathrm{O}^{\prime}$ ahu have a potential evaporation rate 1.3 times the pan evaporation rate. Accordingly, a pan coefficient of 1.3 was used as the "high-range value" in the sensitivity analysis for evergreen-forest land below the fog zone receiving mean annual rainfall greater than 80 in. For all other vegetation types, the pan coefficient was increased by 18 percent or decreased by 18 percent. Recharge decreased 13 percent compared with the 2000-04 base case when the high range of pan coefficients were tested, and increased 15 percent when the low range of pan coefficients were tested.

To test the sensitivity of the water budget to irrigation estimates, irrigation was increased by 20 percent and decreased by 20 percent; the resulting recharges were 11 percent higher and 9 percent lower, respectively, than in the 2000-04 base case.

The results of the sensitivity analysis listed in table 15 and discussed above are based on the change in mean recharge for the entire study area (fig. 1). Individual areas within the study area will have a higher or lower sensitivity to each parameter, depending on the hydrologic characteristics of each area.

\section{Summary and Conclusions}

Increasing ground-water extractions and evidence of a rising transition zone between freshwater and saltwater in the 'Tao aquifer system, the principal source of municipal water for the Island of Maui, have prompted the MDWS to enter into an agreement with the USGS to investigate the longterm sustainability of current and future ground-water-withdrawal scenarios. As part of this investigation, a water-budget method was developed from which (1) historical ground-water recharge was estimated and (2) the effects of agricultural land use and rainfall were analyzed for the period 1926-2004.

Estimated mean ground-water recharge decreased 44 percent from 1979 to 2004 in central and west Maui. Mean ground-water recharge for the period 1926-79 was $693 \mathrm{Mgal} / \mathrm{d}$ and for the period 2000-04, $391 \mathrm{Mgal} / \mathrm{d}$. The decline was relatively steady over the intervening period except for the period 1985-89, during which much higher than average rainfall occurred. Monthly recharge was generally highest in March and lowest in October, coinciding with the highest and lowest monthly rates, respectively, of combined rainfall and irrigation. Irrigation provides a moderating effect on the monthly variation in recharge.

Results from hypothetical land-use scenarios indicate that a cessation of agriculture in central and west Maui would reduce mean ground-water recharge by 18 percent in comparison with current conditions, and a period of drought, identical to that in 1998-2002, would reduce mean ground-water recharge by 27 percent in comparison with current conditions. Mean recharge would decrease 46 percent in comparison with current conditions if this drought were to occur after a cessation of agriculture in central and west Maui.

Reduction in agricultural irrigation, resulting from more efficient irrigation methods and a reduction in agricultural 
land use, are largely responsible for the declining recharge. Recently, periods of lower than average rainfall have had an exacerbating effect. Droughts are transient phenomena, and their effects are generally mitigated by periods of higher than average rainfall. However, the reduction in agricultural irrigation and associated reduction in ground-water recharge in central and west Maui are likely permanent conditions.

\section{References Cited}

Allen, R.G., Pereira, L.S., Raes, Dirk, and Smith, Martin, 1998, Crop evapotranspiration; guidelines for computing crop water requirements: United Nations Food and Agriculture Organization Irrigation and Drainage Paper 56, 300 p.

Austin, Tsutsumi and Associates, Inc., 1991, West Maui water master plan: County of Maui Department of Water Supply, $270 \mathrm{p}$.

Belt, Collins and Associates, Ltd., 1969, A water source development plan for Lahaina District, Island of Maui: Hawai ‘i Division of Water and Land Development Report R33, 101 p.

Bruijnzeel, L.A., 2001, Hydrology of tropical montane cloud forests; a reassessment: Land Use and Water Resources Research, v. 1, p. 1.1-1.18.

Burnham, W.L., Larson, S.P., and Cooper, H.H., Jr., 1977, Distribution of injected wastewater in the saline lava aquifer, Wailuku-Kahului wastewater treatment facility, Kahului, Maui, Hawaii: U.S. Geological Survey Open-File Report 77-469, 58 p.

Caskey, M.C., 1968, The recharge of the Waikapu aquifer, Maui: Honolulu, University of Hawai'i, M.S. thesis, 75 p.

Commission on Water Resource Management, 1990, Water resources protection plan, June 1990: Hawai'i Department of Land and Natural Resources, $2 \mathrm{v}$.

Conover, W.J., 1999, Practical nonparametric statistics (3d ed.): New York, John Wiley and Sons, 584 p.

Division of Water and Land Development, 1970, Water for Kihei-Makena, Island of Maui: County of Maui Department of Water Supply Report R38, 89 p.

Ekern, P.C., 1965, Evapotranspiration of pineapple in Hawaii: Plant Physiology, v. 40, no. 4, p. 736-739.

Ekern, P.C., and Chang, J.H., 1985, Pan evaporation: State of Hawai'i, 1894-1983: State of Hawai 'i, Department of Land and Natural Resources, Division of Water and Land Development, Report R74, 172 p.
Firth, D.J., Whalley, R.D.B., and Johns, G.G., 2003, Distribution and density of the root system of macadamia on krasnozem soil and some effects of legume groundcovers on fibrous root density: Australian Journal of Experimental Agriculture, v. 43, p. 503-514.

Fontaine, R.A., 1996, Evaluation of the surface-water quantity, surface-water quality, and rainfall data-collection programs in Hawaii, 1994: U.S. Geological Survey Water-Resources Investigations Report 95-4212, 125 p.

Fontaine, R.A., 2003, Availability and distribution of base flow in lower Honokohau Stream, Island of Maui, Hawaii: U.S. Geological Survey Water-Resources Investigations Report 03-4060, 37 p.

Foote, D.E., Hill, E.L., Nakamura, Sakuichi, and Stephens, Floyd, 1972, Soil survey of islands of Kauai, Oahu, Maui, Molokai, and Lanai, State of Hawai 'i: U.S. Soil Conservation Service, 232 p.

Fukunaga, L.K., 1978, Some agroclimatic, economic, ecological, and site considerations that condition the practice of drip irrigation in Hawaii's sugar industry: Honolulu, University of Hawai'i, M.S. thesis, 181 p.

Giambelluca, T.W., 1983, Water balance of the Pearl HarborHonolulu basin, Hawai 'i, 1946-1975: Honolulu, University of Hawai'i, Water Resources Research Center Technical Report 151, 151 p.

Giambelluca, T.W., Nullet, M.A., and Schroeder, T.A., 1986, Rainfall atlas of Hawai' $i$ : Hawai 'i Department of Land and Natural Resources, Division of Water and Land Development Report R76, 267 p.

Giambelluca, T.W., and Nullet, Dennis, 1991, Influence of the trade-wind inversion on the climate of a leeward mountain slope in Hawaii: Climate Research, v. 1, p. 207-216.

Giambelluca, T.W., and Nullet, Dennis, 1992a, An automated recording atmometer; 2. Evaporation measurement on a high elevation transect in Hawaii: Agricultural and Forest Meteorology, v. 62, p. 127-138.

Giambelluca, T.W., and Nullet, Dennis, 1992b, Evaporation at high elevations in Hawaii: Journal of Hydrology, v. 136, p. 219-235.

Giambelluca, T.W., and Schroeder, T.A., 1998, Climate, in Juvik, S.P., and Juvik, J.O., eds., Atlas of Hawai 'i (3d ed.): Honolulu, University of Hawai'i Press, p. 49-59.

Hawai'i Department of Business, Economic Development, and Tourism, 2004, The State of Hawai'i data book, 2004: URL http://www.hawaii.gov/dbedt/info/economic/databook/db04 [accessed Feb. 2006]. 
Izuka, S.K., Oki, D.S., and Chen, C., 2005, Effects of irrigation and rainfall reduction on ground-water recharge in the Lihue Basin, Kauai, Hawaii: U.S. Geological Survey Scientific Investigations Report 2005-5146, 48 p.

Jones, C.A., 1980, A review of evapotranspiration studies in irrigated sugarcane in Hawaii: Hawaiian Planters' Record, v. 59, p. 195-214.

Juvik, J.O., and Ekern, P.C., 1978, A climatology of mountain fog on Mauna Loa, Hawaii Island: Honolulu, University of Hawai ‘i, Water Resources Research Center Technical Report 118, 63 p.

Lee, H.A.,1927, A committee report on the distribution of sugarcane roots in the soil: Association of Hawaiian Sugar Technologists Annual Meeting, 6th, Honolulu, 1927, Reports, p. 56-69.

Macdonald, G.A., Abbott, A.T., and Peterson, F.L., 1983, Volcanoes in the sea, the geology of Hawaii ( $2 \mathrm{~d}$ ed.): Honolulu, University of Hawaii Press, 517 p.

Meyer, William, and Presley, T.K., 2000, The response of the Iao aquifer to ground-water development, rainfall, and landuse practices between 1940 and 1998, Island of Maui, U.S. Geological Survey Water-Resources Investigations Report 00-4223, 60 p.

Minyard, W.P., Giambelluca, T.W., and Nullet, Dennis, 1994, Elevational patterns of climate on the leeward slope of east Maui, Hawaii: Honolulu, University of Hawai 'i at Mānoa, Cooperative National Park Resources Studies Unit Technical Report 92, 50 p.

National Climatic Data Center, 2002, Cooperative summary of the day, TD3200, period of record through 2001, Western United States and Pacific Islands: CD-ROM.

National Climatic Data Center, 2003, Cooperative summary of the day-CDMP-PRE 1949, TD-3206, version 2: CD-ROM.

National Oceanic and Atmospheric Administration, 2000, Maui 2000 land cover data: Coastal Services Center, URL http://www.csc.noaa.gov/crs/lca/hawaii.html [accessed Jan. 2004].

Natural Resources Conservation Service, 2001, Soil Survey Geographic (SSURGO) database: URL http://www.ncgc. nrcs.usda.gov/branch/ssb/products/ssurgo/data/hi.html [accessed Dec. 2003].

Oki, D.S., 2002, Reassessment of ground-water recharge and simulated ground-water availability for the Hawi area of North Kohala, Hawaii: U.S. Geological Survey WaterResources Investigations Report 02-4006, 62 p.

Penman, H.L., 1956, Evaporation; an introductory survey: Netherlands Journal of Agricultural Science, v. 4, p. 9-29.
Scholl, M.A., Gingerich, S.B., Loope, L.L., Giambelluca, T.W., and Nullet, M.A., 2004, Quantifying the importance of fog drip to ecosystem hydrology and water resources in windward and leeward tropical montane cloud forests on east Maui, Hawaii: Venture Capital Project final report, July 2004, URL http://water.usgs.gov/nrp/proj.bib/hawaii/ vcp_final_report.htm [accessed Feb. 15, 2006].

Scott, G.A.J., 1975, Relationships between vegetation cover and soil avalanching in Hawaii: Association of American Geographers Proceedings, v. 7, p. 208-212.

Searcy, J.K., 1959, Flow-duration curves, in Low-flow techniques, pt. 2 of Manual of hydrology: U.S. Geological Survey Water-Supply Paper 1542-A, 33 p.

Shade, P.J., 1996, Water budget for the Lahaina District, Island of Maui, Hawaii: U.S. Geological Survey Water-Resources Investigations Report 96-4238, 27 p.

Shade, P.J., 1997, Water budget for the Iao area, Island of Maui, Hawaii: U.S. Geological Survey Water-Resources Investigations Report 97-4244, 25 p.

Shade, P.J., 1999, Water budget of east Maui, Hawaii: U.S. Geological Survey Water-Resources Investigations Report 98-4159, $36 \mathrm{p}$.

Sherrod, D.R., Nishimitsu, Yoshitomo, and Tagami, Takahiro, 2003, New K-Ar ages and the geologic evidence against rejuvenated-stage volcanism at Haleakalā, east Maui, a postshield-stage volcano of the Hawaiian island chain: Geological Society of America Bulletin, v. 115, no. 6, p. 683-694.

State of Hawaii, 1976, Land use and land cover of the main Hawaiian Islands as of 1976: URL http://www.state.hi.us/ dbedt/gis/data [accessed Dec. 2004].

State of Hawaii, 2005, Watershed unit boundary polygons and attributes: URL http://www.state.hi.us/dbedt/gis/data [accessed Mar. 2005].

Stearns, H.T., and Macdonald, G.A., 1942, Geology and ground-water resources of the Island of Maui, Hawaii: Hawai'i Division of Hydrography Bulletin 7, 344 p.

Takasaki, K.J., 1972, Preliminary report on the water resources of central Maui: Hawai 'i Department of Land and Natural Resources, Division of Water and Land Development Circular C62, $59 \mathrm{p}$.

Tenorio, P.A., Young, R.H.F., Burbank, N.C., Jr., and Lau, L.S., 1970, Identification of irrigation return water in the sub-surface; phase III, Kahuku, Oahu and Kahului and Lahaina, Maui: Honolulu, University of Hawai 'i, Water Resources Research Center Technical Report 44, 53 p.

Thornthwaite, C.W., and Mather, J.R., 1955, The water balance: Publications in Climatology, v. 8, no. 1, p. 1-104. 
Wahl, K.L., and Wahl, T.L., 1995, Determining the flow of Comal Springs at New Braunfels, Texas: Texas Water '95, a Component Conference of the American Society of Civil Engineers International Conference on Water Resources, 1st, San Antonio, Tex., 1995, Proceedings, p. 77-86.

Wilcox, Carol, 1996, Sugar water; Hawaii's plantation ditches: Honolulu, University of Hawai ‘i Press, 191 p.

Yamanaga, George, and Huxel, C.J., 1969, Preliminary report on the water resources of the Lahaina District, Maui: Hawai 'i Department of Land and Natural Resources, Division of Water and Land Development Circular C51, 47 p.
Yamanaga, George, and Huxel, C.J., 1970, Preliminary report on the water resources of the Wailuku area, Maui: Hawai ' $i$ Department of Land and Natural Resources, Division of Water and Land Development Circular C61, 43 p. 


\section{Appendix A. Description of USGS Climate Network and Methods for Calculating Potential Evapotranspiration}

\section{Purpose}

An analysis of currently available evapotranspiration data for the study area revealed an absence of data on West Maui Mountain (figs. 1, 8), probably owing to the remote and rugged terrain. To gain a better understanding of evapotranspiration in this area, a network of three climate stations was established between November 2003 and November 2005, to collect data for the calculation of potential evapotranspiration by Penman's (1948) method. Potential-evapotranspiration estimates are useful for estimating evapotranspiration in wet tropical environments (Bidlake and others, 1996).

\section{Climate Stations}

Location.-Only three climate stations were available for the climate network in this study, and so every attempt was made to place the stations along a northeast-to-southwest transect, parallel to the prevailing wind direction. However, owing to the ruggedness of the terrain and the remoteness of the area, an ideally oriented transect was infeasible (fig. 8).

Equipment and data collection interval.-Instruments at each climate station measured net radiation (3-6 ft above vegetation), soil-heat flux, volumetric soil-water content, soil temperature, air temperature (3-6 ft above vegetation), relative humidity (3-6 ft above vegetation), wind speed (3-6 ft above vegetation), and rainfall. Equipment and sensors at the three climate stations were nearly identical, except for three additional throughfall collectors (for collecting rainfall that passed through the forest canopy) at the Kaulalewelewe station. An electronic data logger measured sensors and calculated and recorded data. For most sensors, the data logger made measurements every $10 \mathrm{~s}$. On the hour, the data logger calculated and stored the average of the 10-s measurements made during the previous hour. Soil moisture was measured and recorded hourly from an instantaneous measurement made by the data logger. Rainfall and throughfall data collected during the previous hour were summed and recorded on the hour.

\section{General Description}

Ри ' и Kukui climate station.-Station 101 (USGS sta. 205327156351101) was located at an elevation of approximately 5,770 ft above sea level, on a slope (approx 10-percent grade) near the summit of West Maui Mountain (fig. 8). The ground surface was covered in stunted-growth shrubs, generally 6 in. high. Soil at the site was saturated, with pooled water observed on bare soil during almost every field visit. The station was operated from September 29, 2004, to October 3, 2005. Problems with the soil-moisture probe, possibly due to the saturated soil, prevented the collection of soil-moisture data during the monitoring period. Also, no wind-speed data were collected from April 27, 2005, to September 20, 2005, owing to an instrument malfunction.

Kaulalewelewe climate station.-Station 201 (USGS sta. 205604156365801) was located at an elevation of approximately 2,980 ft above sea level, on a flat area of the northwest slope of West Maui Mountain (fig. 8), with a fetch of about $100 \mathrm{ft}$. The ground surface was covered with shrubs and small trees (shrubs, approx 1-3 ft high; trees, 6-9 ft high). Throughfall collectors were placed nearby in a stand of small trees (6-9 ft high). The station was operated from November 23,2003 , to November 28, 2005. No wind-speed data were collected from March 24, 2005, to the end of the monitoring period, owing to sensor failure.

Kahakuloa climate station.-Station 301 (USGS sta. 205712156332401) was located at an elevation of approximately 2,500 ft above sea level, on a flat area of the northeast slope of West Maui Mountain (fig. 8), with a fetch of about $400 \mathrm{ft}$. The ground surface was covered with shrubs (approx 3 $\mathrm{ft}$ high). The station was operated from September 29, 2004, to September 27, 2005. Wind-speed data were only sporadically collected from April 24, 2005, to the end of the monitoring period, owing to an instrument malfunction.

\section{Potential Evapotranspiration}

Penman's (1948) method was chosen over other methods for estimating evapotranspiration on West Maui Mountain because (1) soil-moisture availability is practically unlimited, owing to high rainfall; and (2) upwind homogeneous land cover and fetch are limited by sharp elevation gradients, making application of other methods difficult. Penman's equation was used to calculate hourly potential evapotranspiration from the measured climate data collected at each station. Mean monthly potential evapotranspiration (fig. A1) was then calculated from the hourly values.

Penman's (1948) equation can be expressed as

$$
P E=\frac{H \Delta+\gamma E_{\mathrm{a}}}{\Delta+\gamma}
$$

where

$$
\begin{aligned}
P E= & \text { potential evapotranspiration }[\mathrm{mm} / \mathrm{d}], \\
H= & \text { net radiation minus soil-heat conduction, } \\
& \quad \text { expressed in evaporation-equivalent units } \\
& \quad[\mathrm{mm} / \mathrm{d}],
\end{aligned}
$$


pressure versus temperature $[\mathrm{mbars} / \mathrm{K}]$, $\gamma=$ the psychrometric constant [mbars/K], and $E_{\mathrm{a}} \quad=$ the aerodynamic term in Penman's equation $[\mathrm{mm} / \mathrm{d}]$.

The energy term $(H)$ is a function of net radiation, soilheat flux, soil temperature, and soil moisture:

$$
H=0.0353\left(R_{n e t}-G\right),
$$

where

$$
\begin{aligned}
R_{\text {net }}= & \text { net radiation }\left[\mathrm{W} / \mathrm{m}^{2}\right], \\
G= & \text { soil-heat conduction }\left[\mathrm{W} / \mathrm{m}^{2}\right], \text { and } \\
0.0353= & \text { the factor to convert energy flux in } \\
& \text { watts per square meter to evaporation } \\
& \text { equivalent units in millimeters per day } \\
& {\left[(\mathrm{mm} / \text { day }) /\left(\mathrm{W} / \mathrm{m}^{2}\right)\right] . }
\end{aligned}
$$

The term $G$ is a function of soil-heat flux ( $S H F$, in W/ $\left.\mathrm{m}^{2}\right)$ and the change in sensible heat of the soil $\left(S\right.$, in $\left.\mathrm{W} / \mathrm{m}^{2}\right)$, calculated from changes in soil temperature over time:

$$
G=S H F+S,
$$

where

$$
S=\frac{\left(T_{s}\right)_{i}-\left(T_{s}\right)_{i-l}}{t_{i}-t_{i-l}} D\left(\rho_{b} C_{s}+\theta \rho_{w} C_{w}\right)
$$

(see Izuka and others, 2005)

$$
\begin{aligned}
S & =\text { the change in sensible heat energy }\left[\mathrm{W} / \mathrm{m}^{2}\right], \\
T_{s} & =\text { the mean soil temperature }[\mathrm{K}], \\
t & = \\
D & =
\end{aligned}
$$

The volumetric soil-moisture content, was monitored with a soil-moisture probe. Results from the probe were checked against a laboratory analysis of soil samples taken at each station.

The aerodynamic term $\left(E_{a}\right)$ is a function of wind speed and vapor-pressure deficit:

$$
E_{a}=(0.263+0.123 U)\left(e_{s}-e\right)
$$

where

$$
\begin{aligned}
U= & \text { the wind speed }[\mathrm{m} / \mathrm{s}], \text { and } \\
e_{s}-e= & \text { vapor-pressure deficit, the difference } \\
& \text { between saturation vapor pressure }\left(e_{s}\right) \text { and } \\
& \text { ambient vapor pressure }(e) \text { [mbars]. }
\end{aligned}
$$

The saturation vapor pressure $\left(e_{\mathrm{s}}\right)$ is estimated as a function of air temperature $(T[\mathrm{~K}])$, using Goff and Gratch's (1946) relation:

$$
e_{s}=10^{X}
$$

where

$$
\begin{aligned}
x= & -7.90298\left(\frac{373.16}{T}-1\right) \\
& +5.02808 \times \log \left(\frac{373.16}{T}\right) \\
& -1.3816 \times 10^{-7}\left(10^{11.344\left[1-\frac{T}{373.16}\right]}-1\right) \\
& +8.1328 \times 10^{-3}\left(10^{-3.49149\left[\frac{373.16}{T}-1\right]}-1\right) \\
& +3.00571
\end{aligned}
$$

and

$$
T \quad=\text { air temperature }[\mathrm{K}] .
$$

The ambient air vapor pressure $(e)$ is a function of $e_{s}$ and relative humidity $(R H)$ :

$$
e=e_{s} \frac{R H}{100}
$$

where

$$
R H \quad=\text { relative humidity [percent] } .
$$

The slope of the curve of saturation vapor pressure versus temperature $(\Delta)$ is a function of air temperature and $e_{s}$ :

$$
\begin{aligned}
\Delta & =373.15\left(\frac{e_{s}}{T^{2}}\right) 13.3185-3.952 t_{g} \\
& -1.9335 t_{g}^{2}-0.5196 t_{g}^{3}
\end{aligned}
$$

where

$$
t_{g}=1-\frac{373.15}{T} .
$$

The psychrometric constant $(\gamma)$ is not actually constant but varies with temperature and atmospheric pressure. This parameter was calculated by using the formula of Storr and Den Hartog (1975) as: 


$$
\gamma=0.3863 \frac{P_{a t m}}{\lambda}+0.02694 R H\left(\frac{10^{\frac{7.5 T}{237.3+T}}}{\lambda}\right)
$$

where

$$
\begin{aligned}
P_{a t m} & =\text { atmospheric pressure }[\mathrm{mbars}], \\
\lambda & =\text { the latent heat of vaporization }[\mathrm{cal} / \mathrm{g}](\gamma= \\
& 597.3-0.5653 \mathrm{~T}), \text { and } \\
T & =\text { air temperature }\left[{ }^{\circ} \mathrm{C}\right] .
\end{aligned}
$$

For all stations, atmospheric pressure used in the potential-evapotranspiration calculation was estimated by using the following equation (National Oceanic and Atmospheric Administration, 2006):

$$
P_{a t m}=1,013.25\left(1.0-\frac{A_{s}}{44,307.69}\right)^{5.25}
$$

where

$$
\begin{aligned}
A_{s}= & \text { the elevation at the potential } \\
& \text { evapotranspiration station [meters above } \\
& \text { mean sea level]. }
\end{aligned}
$$

Estimates substituted for missing data in the potentialevapotranspiration calculation.-All stations had periods of missing hourly data that resulted from instrument malfunctions. However, no loss in net radiation data occurred, which is the primary factor limiting evapotranspiration under humid tropical conditions (Calder, 1998) present at each of the climate stations.

To calculate potential evapotranspiration, the missing hourly data were substituted with estimates calculated from a regression relation between the station in question and one of the other two remaining sites (the site with the strongest correlation). All three sites had significant gaps in the wind-speed record. In addition, the Pu'u Kukui site had several failures with soil instruments.

$P и$ ' $и$ Kukui estimates.-The wind-speed sensor and all soil probes are missing a significant number of data. Soil probes were not installed at the site until March 23, 2005. Soil sensors included soil temperature $(T)$, two soil-heat flux plates (SHF1, SHF2), and soil moisture (SM). After installation, only the $S H F 1$ and $T_{s}$ sensors recorded reliable data until the end of the collection period. The ground at this site is saturated, with ponded water observed around the climate station on nearly every field visit, possibly contributing to failure of the soil probes.

Missing wind-speed data from the $\mathrm{Pu}$ 'u Kukui station were replaced by estimates, using a regression relation between wind-speed data collected at the Kahakuloa and $\mathrm{Pu}$ ' $\mathrm{u}$ Kukui stations. This replacement did not fill all the data gaps, however, and so the regression equation derived from available wind-speed data at the Kaulalewelewe and $\mathrm{Pu}$ ' $\mathrm{u}$ Kukui stations were used to fill as many remaining gaps as possible:

$$
\begin{gathered}
W S_{101}=0.705+1.254 \times W S_{301}, \\
\mathrm{R}^{2}=0.650
\end{gathered}
$$

$$
\begin{gathered}
W S_{101}=1.147+1.239 \times W S_{201}, \\
\mathbf{R}^{2}=0.597
\end{gathered}
$$

where

$$
\begin{aligned}
& W S_{101}=\text { the wind speed at the Pu'u Kukui station, } \\
& W S_{201}=\text { the wind speed at the Kaulalewelewe } \\
& \text { station, and }
\end{aligned}
$$

The soil-moisture probe at the Pu'u Kukui station failed to give any accurate results. To estimate soil moisture at this site, the soil-moisture measurements at the Kahakuloa station were shifted by a constant determined by comparing the soil-moisture measurements at the Kahakuloa station with a soil-moisture value obtained through laboratory analysis of a manually extracted soil sample of known volume from the $\mathrm{Pu}$ 'u Kukui station:

$$
S M_{101}=S M_{301}+3.00,
$$

where

$$
\begin{aligned}
& S M_{101}=\text { the soil moisture at the } \mathrm{Pu} \text { 'u Kukui station, } \\
& S M_{301}=\text { and }
\end{aligned}
$$

Missing hourly soil-temperature data from the $\mathrm{Pu}$ ' $\mathrm{u}$ Kukui station were replaced by estimates, using a regression relation between the soil-temperature data collected at the Kahakuloa and $\mathrm{Pu}$ 'u Kukui stations:

$$
\begin{gathered}
\left(T_{s}\right)_{101}=-2.239+0.908\left(T_{s}\right)_{301}, \\
\mathrm{R}^{2}=0.589
\end{gathered}
$$

where

$$
\begin{aligned}
& \left(T_{s}\right)_{101}=\text { the soil temperature at the Pu'u Kukui } \\
& \text { station and } \\
& \left(T_{s}\right)_{301}=\begin{array}{l}
\text { the soil temperature at the Kahakuloa } \\
\text { station. }
\end{array}
\end{aligned}
$$

Two soil-heat flux plates were installed at the Pu'u Kukui station. Missing SHF1 data were replaced by estimates, using a regression relation between the $S H F 2$ data collected at the Kaulalewelewe station and those collected at the $\mathrm{Pu}$ 'u Kukui station. Missing soil-heat flux 2 data from the Pu'u Kukui station were not used in the potential-evapotranspiration calculations:

$$
\begin{gathered}
S H F 1_{101}=-0.583+1.03 \times S H F 2_{201}, \\
\mathrm{R}^{2}=0.607
\end{gathered}
$$


where

$$
\begin{aligned}
& S H F 1_{101}=\text { the soil-heat flux at the } \mathrm{Pu} \text { 'u Kukui station, } \\
& \text { and } \\
& S H F 2_{201}=\begin{array}{l}
\text { the soil temperature at the Kaulalewelewe } \\
\text { station. }
\end{array}
\end{aligned}
$$

Kaulalewelewe estimates.-Missing wind-speed data from the Kaulalewelewe station were replaced by estimates, using a regression relation between the wind-speed data collected at the Pu'u Kukui and Kaulalewelewe stations. Not all the data gaps were filled, and so the regression equation derived from the available wind-speed data at the Kahakuloa and Kaulalewelewe stations was used to fill as many of the remaining gaps as possible:

$$
\begin{gathered}
W S_{201}=0.700+0.482 \times W S_{101}, \\
\mathrm{R}^{2}=0.597 \\
W S_{201}=0.881+0.649 \times W S_{301}, \\
\mathrm{R}^{2}=0.533
\end{gathered}
$$

Kahakuloa estimates.-Missing wind-speed data from the Kahakuloa station were replaced by estimates, using a regression relation between the wind-speed data collected at the $\mathrm{Pu}$ 'u Kukui and Kahakuloa stations. This replacement did not fill all the data gaps, and so the regression equation derived from the available wind-speed data at the Kaulalewelewe and Kahakuloa stations was used to fill as many of the remaining gaps as possible:

$$
\begin{aligned}
& \begin{array}{c}
W S_{301}=0.846+0.518 \times W S_{101}, \\
\mathrm{R}^{2}=0.650
\end{array} \\
& W S_{301}=1.039+0.820 \times W S_{201} \text {, } \\
& \mathrm{R}^{2}=0.533
\end{aligned}
$$

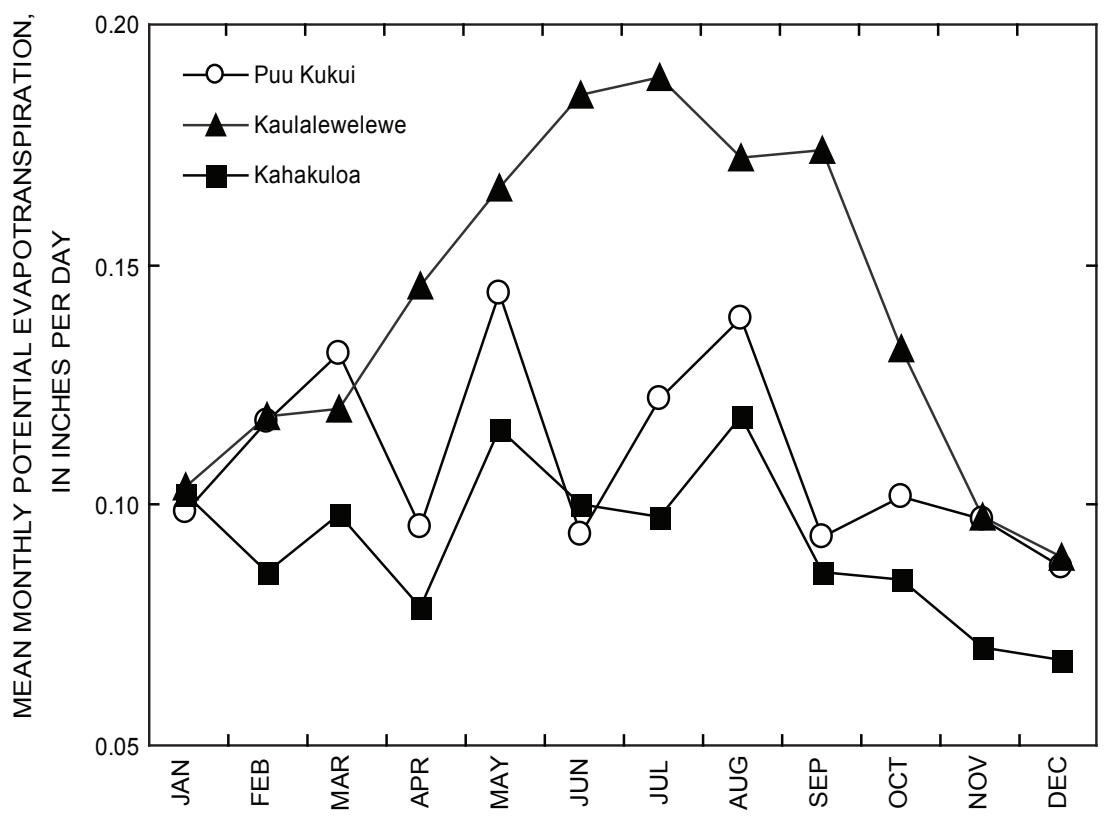

Figure A1. Mean monthly potential evapotranspiration at the climate stations on West Maui Mountain. 


\section{References Cited}

Bidlake, W.R., Woodham, W.M., and Lopez, M.A., 1996, Evapotranspiration from areas of native vegetation in westcentral Florida: U.S. Geological Survey Water-Supply Paper $2430,35 \mathrm{p}$.

Calder, I.R., 1998, Water use by forests, limits and controls: Tree Physiology, v. 18, p. 625-631.

Ekern, P.C., and Chang, J.H., 1985, Pan evaporation: State of Hawai 'i, 1894-1983: Hawai' 'i Department of Land and Natural Resources, Division of Water and Land Development Report R74, 172 p.

Goff, J.A., and Gratch, S., 1946, Low-pressure properties of water from $-160^{\circ}$ to $212^{\circ} \mathrm{F}$, in of the American Society of Heating and Ventilating Engineers Transactions, p. 95-122, presented at the 52d annual meeting of the American Society of Heating and Ventilating Engineers, New York.
Izuka, S.K., Giambelluca, T.W., and Nullet, M.A., 2005, Potential evapotranspiration on Tutuila, American Samoa: U.S. Geological Survey Scientific Investigations Report 2005-5200, $40 \mathrm{p}$.

National Oceanic and Atmospheric Administration, 2006, Station pressure: URL http://www.srh.noaa.gov/elp/wxcalc/ formulas/stationpressure.html [accessed Dec. 2006].

Penman, H.L., 1948, Natural evaporation from open water, bare soil, and grass: Royal Society of London Proceedings, ser. A, v. 193, p. 120-146.

Storr, D., and Den Hartog, G., 1975, Gamma-the psychrometer non-constant: Journal of Applied Meteorology, v. 14, p. 1397-1398. 


\section{$\frac{1}{4}$}

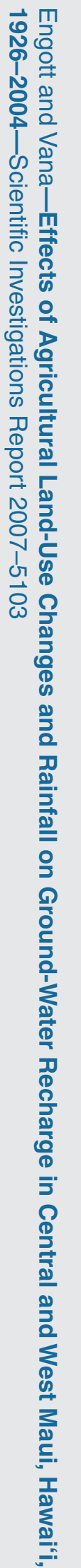

8 Printed on recycled paper 